\title{
Fiscal Year 2012 Revegetation Assessment
}

November 2012

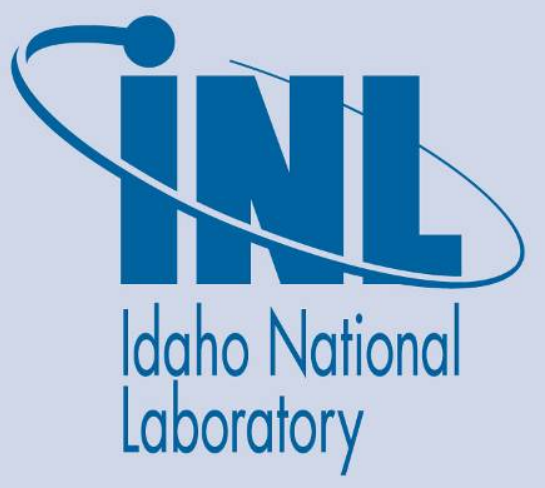

The INL is a U.S. Department of Energy National Laboratory operated by Battelle Energy Alliance 


\section{DISCLAIMER}

This information was prepared as an account of work sponsored by an agency of the U.S. Government. Neither the U.S. Government nor any agency thereof, nor any of their employees, makes any warranty, expressed or implied, or assumes any legal liability or responsibility for the accuracy, completeness, or usefulness, of any information, apparatus, product, or process disclosed, or represents that its use would not infringe privately owned rights. References herein to any specific commercial product, process, or service by trade name, trade mark, manufacturer, or otherwise, does not necessarily constitute or imply its endorsement, recommendation, or favoring by the U.S. Government or any agency thereof. The views and opinions of authors expressed herein do not necessarily state or reflect those of the U.S. Government or any agency thereof. 

INL/EXT-12-27776

\section{Fiscal Year 2012 Revegetation Assessment}

November 2012

\section{Idaho National Laboratory \\ Idaho Falls, Idaho 83415}

Prepared for the

U.S. Department of Energy

Office of Nuclear Energy

Under DOE Idaho Operations Office

Contract DE-AC07-05ID14517 



\begin{abstract}
This report summarizes the Fiscal Year 2012 Revegetation Assessment by Battelle Energy Alliance, LLC. This assessment was conducted to supplement documentation related to the Storm Water Pollution Prevention Plan for Construction Activities and to ensure that disturbed vegetation and soil at various locations are being restored. This report provides the following information for each site being monitored by the Idaho National Laboratory Environmental Support and Services:

- Summary of each site

- Assessment of vegetation status and site stabilization at each location

- Actions and Resolutions for each site.

Ten disturbed sites were evaluated for this assessment. Six have achieved final stabilization. The remaining four sites not meeting the criteria for final stabilization will be evaluated again in the next fiscal year.
\end{abstract}




\section{CONTENTS}

ABSTRACT

ACRONYMS

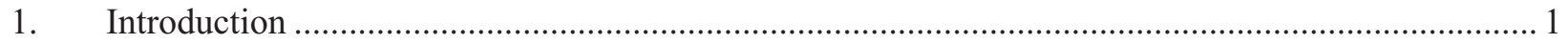

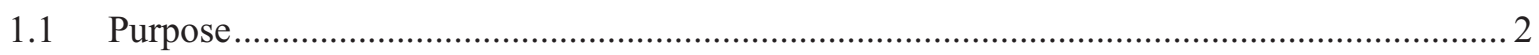

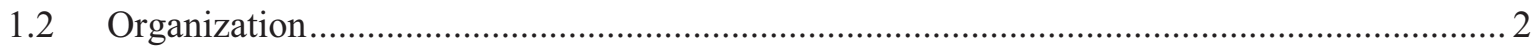

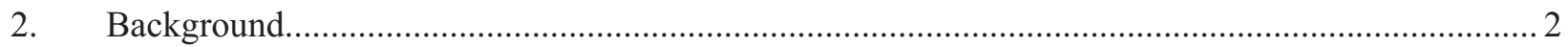

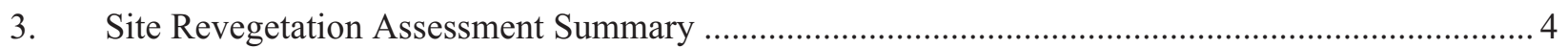

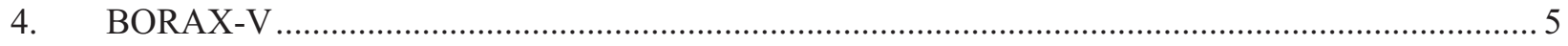

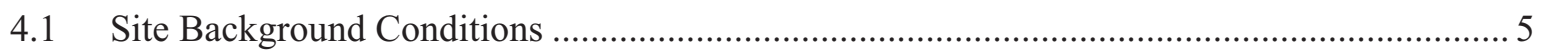

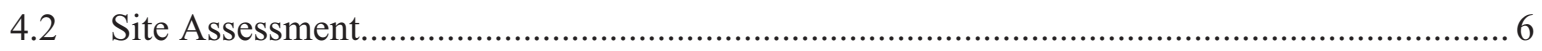

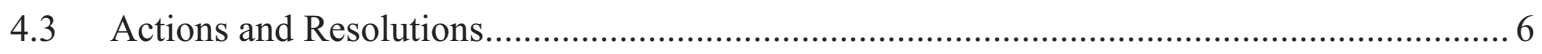

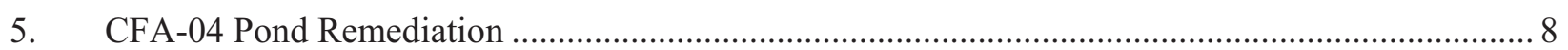

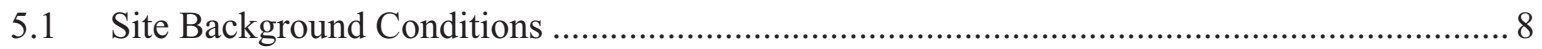

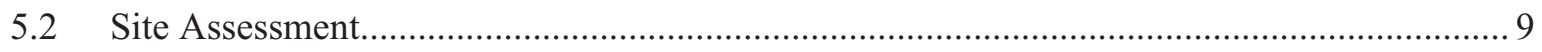

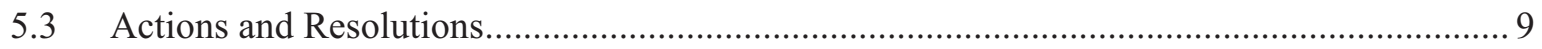

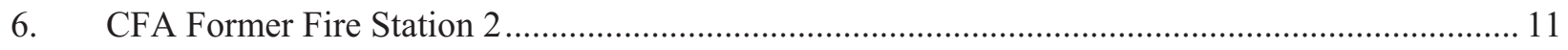

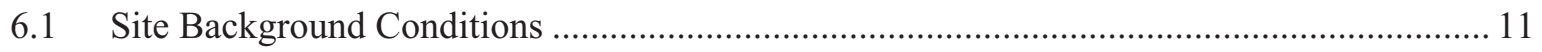

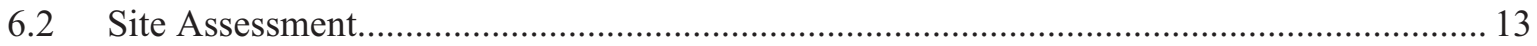

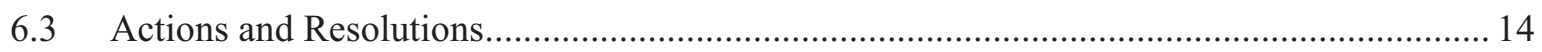

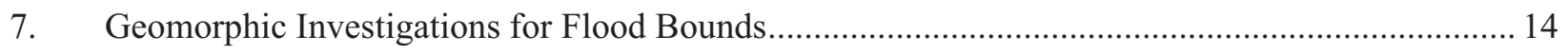

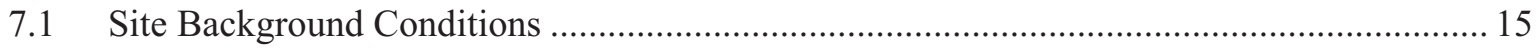

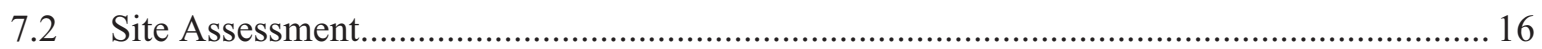

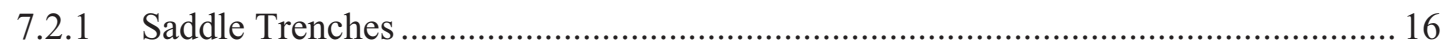

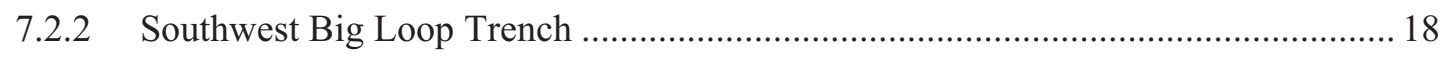

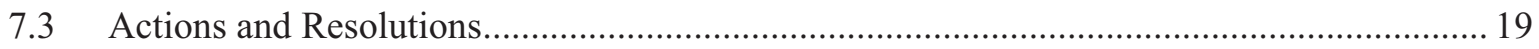

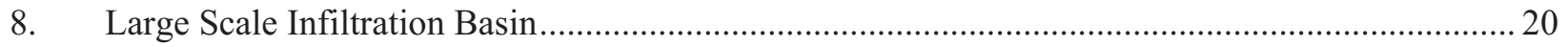

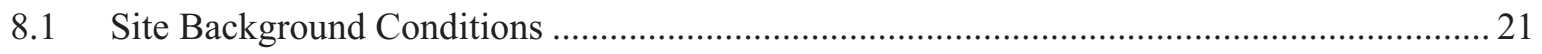

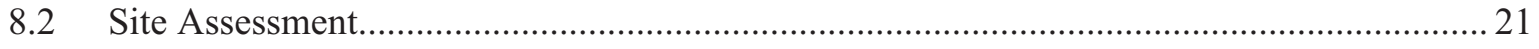

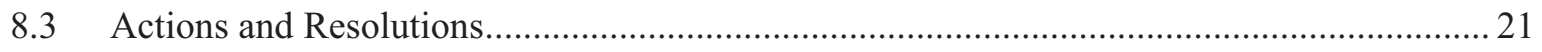

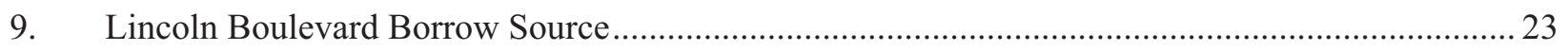

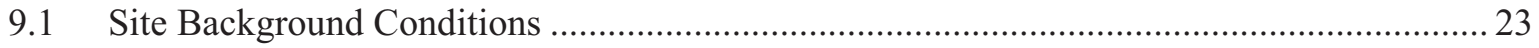

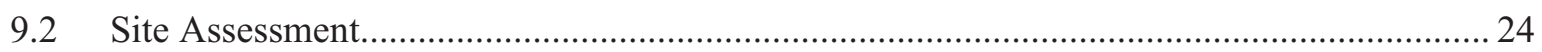

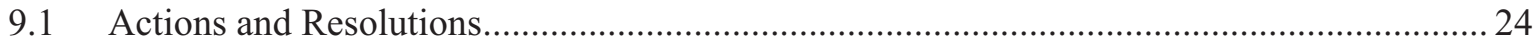


10. Materials and Fuels Complex Industrial Waste Pond.................................................................2 26

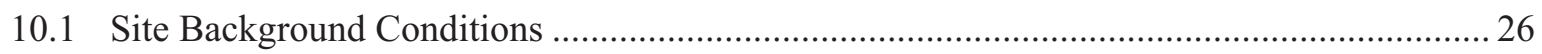

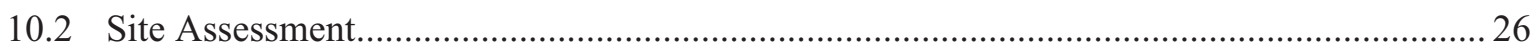

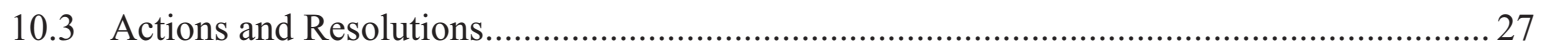

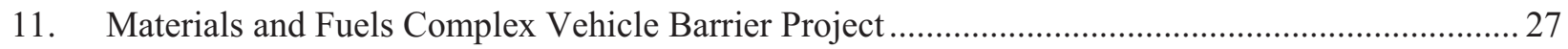

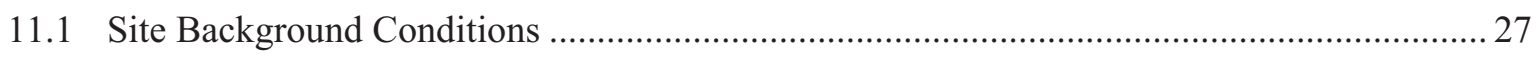

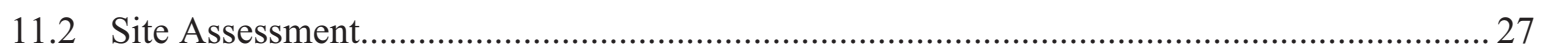

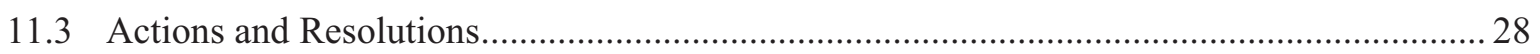

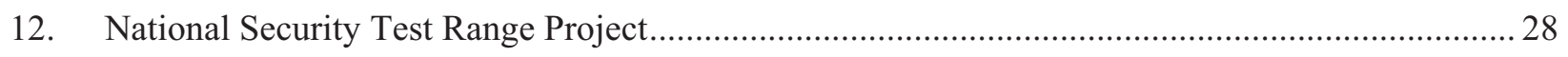

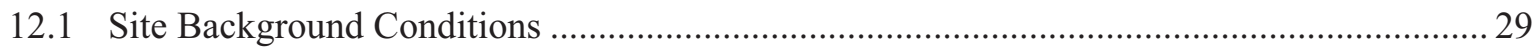

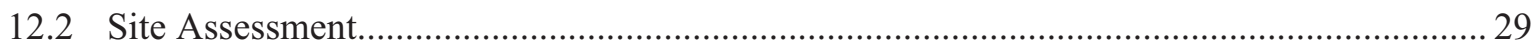

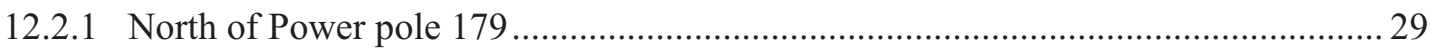

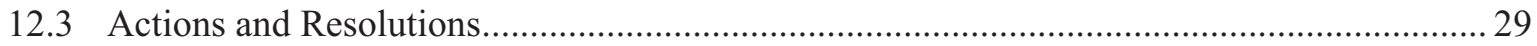

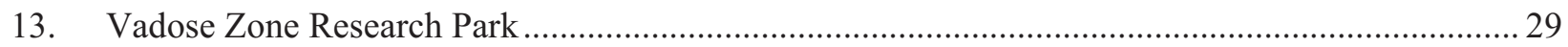

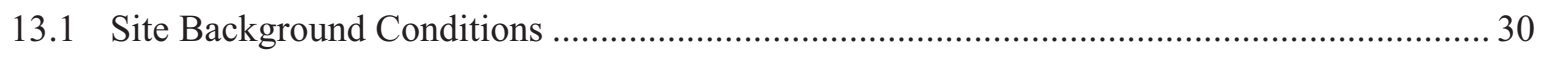

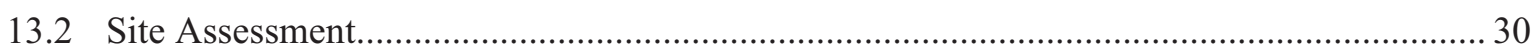

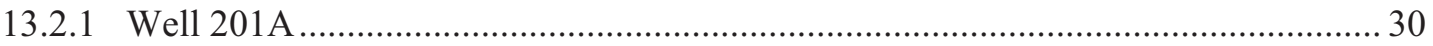

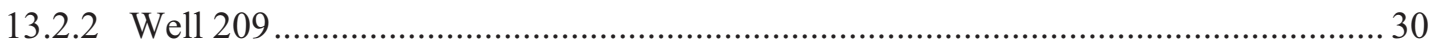

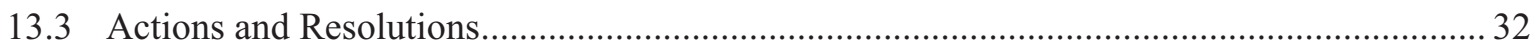

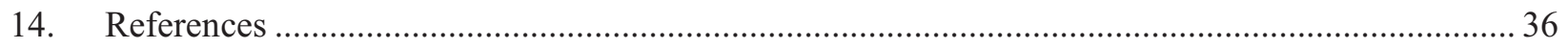

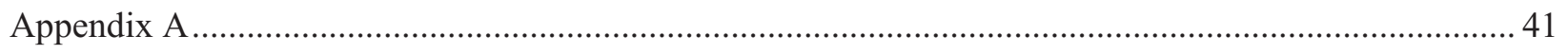

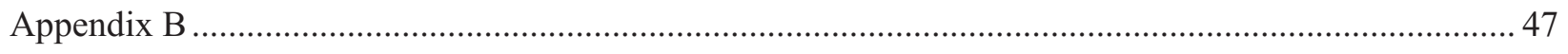

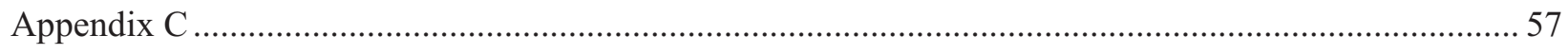

FIGURES

Figure 1. Map of the BORAX-V Revegetation Area........................................................................... 7

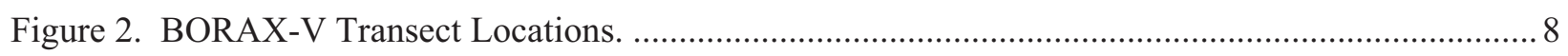

Figure 3. Map of the CFA-04 Pond Remediation Revegetation Area. .................................................... 10

Figure 4. CFA-04 Pond Remediation Transect Locations. ....................................................................... 11

Figure 5. Map of the CFA Former Fire Station 2 Revegetation Site ..................................................... 12

Figure 6. CFA Former Fire Station 2 Disturbed Area Transects. .......................................................... 13

Figure 7. CFA Former Fire Station 2 Background Transect............................................................. 14

Figure 8. Map of the Geomorphic Investigations Project ..................................................................... 15

Figure 9. North and South Saddle Trenches Disturbed Area Transects................................................. 16

Figure 10. Geomorphic Investigations for Flood Bounds Background Area Transect............................. 17 
Figure 11. Southwest Big Loop Trench Disturbed Area Transect........................................................ 18

Figure 12. Map of the Large Scale Infiltration Basin. ......................................................................... 22

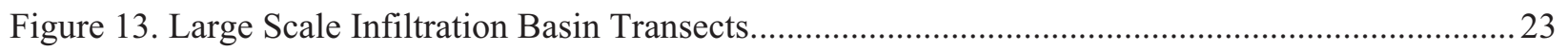

Figure 14. Map of the Lincoln Boulevard Borrow Source. ...............................................................25

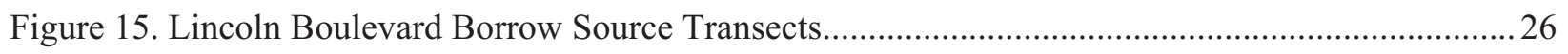

Figure 16. Map of the Vadose Zone Research Park............................................................................. 31

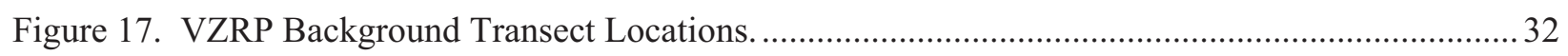

Figure 18. VZRP Well 201A Disturbed Area Transect Locations. .......................................................... 33

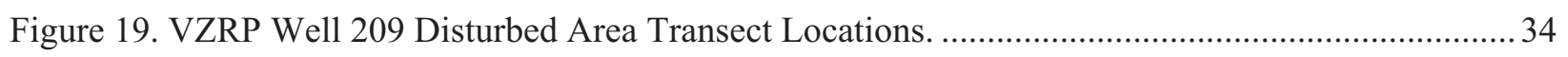

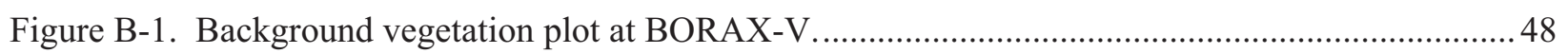

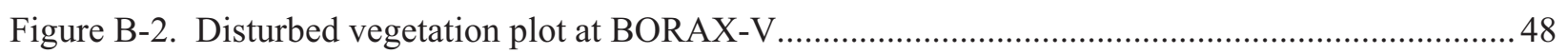

Figure B-3. Background Vegetation Plot at CFA-4 Pond Remediation Site.......................................... 49

Figure B-4. Disturbed Vegetation Plot at CFA-04 Pond Remediation Site............................................ 49

Figure B-5. Background Vegetation Plot at the CFA Former Fire Station 2 Site....................................50

Figure B-6. Disturbed Vegetation Plot at the CFA Former Fire Station 2 Site. ..................................... 50

Figure B-7. Background Vegetation Plot at the Geomorphic Investigations for Flood Bounds................ 51

Figure B-8. Disturbed Vegetation Plot at the North Saddle Trench. ........................................................51

Figure B-9. Disturbed Vegetation Plot at the South Saddle Trench. ........................................................ 52

Figure B-10. Disturbed Vegetation Plot at the Southwest Big Loop Trench...........................................52

Figure B-11. Background Vegetation Plot at the Large Scale Infiltration Basin....................................5

Figure B-12. Disturbed Vegetation Plot at the Large Scale Infiltration Basin. .......................................53

Figure B-13. Background Vegetation Plot at the Lincoln Boulevard Borrow Source..............................5

Figure B-14. Disturbed Vegetation Plot for the Lincoln Boulevard Borrow Source................................5 54

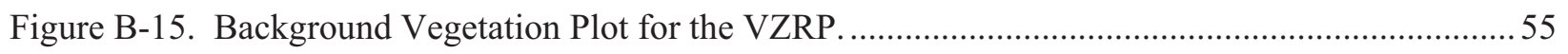

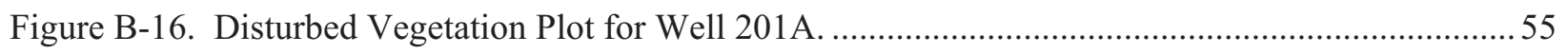

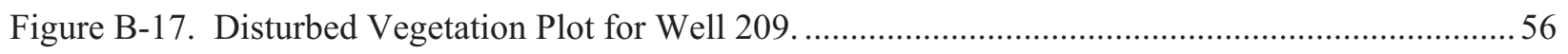

\section{TABLES}

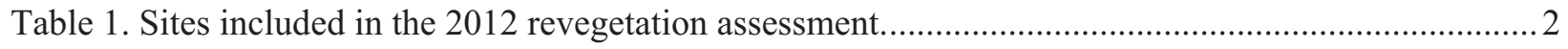

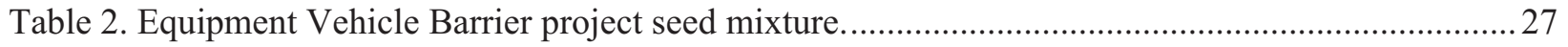

Table 3. Table showing T-25 road sites where seeding was recommended. …......................................28

Table 4. Recommended seed mixture for T-25 road disturbed sites.....................................................29

Table A-1. Comparison of BORAX-V revegetation to background vegetation. ...................................... 42 
Table A-2. Comparison of CFA-04 Pond Remediation revegetation to background vegetation. 42

Table A-3. Comparison of CFA Former Fire Station II revegetation to background vegetation. 43

Table A-4. Comparison of revegetation of Geomorphic Investigations for Flood Bounds North Saddle Trench to background vegetation.

Table A-5. Comparison of revegetation of Geomorphic Investigations for Flood Bounds South Saddle Trench to background vegetation.

Table A-6. Comparison of revegetation of Geomorphic Investigations for Flood Bounds Southwest Big Loop Trench to background vegetation.

Table A-7. Comparison of revegetation of Large Scale Infiltration Basin to background vegetation........ 45

Table A-8. Comparison of revegetation of Lincoln Blvd Borrow Source to background vegetation......... 45

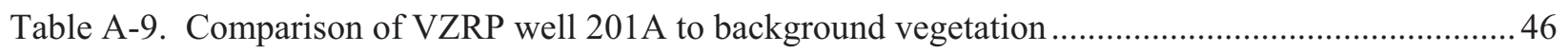

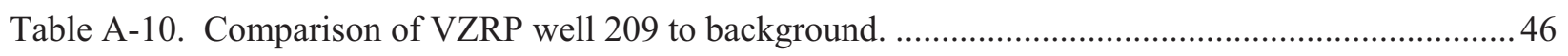

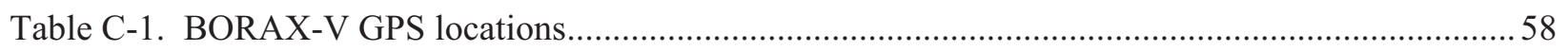

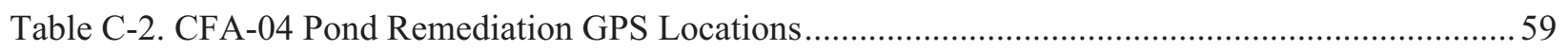

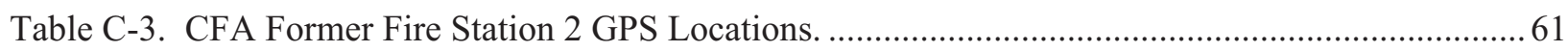

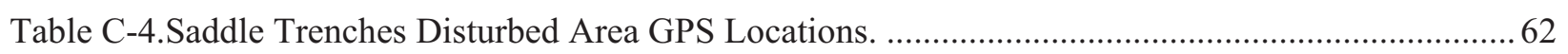

Table C-5. Southwest Big Loop Disturbed Area GPS Locations. .......................................................... 62

Table C-6. Geomorphic Investigations for Flood Bounds Background GPS Locations. ......................... 63

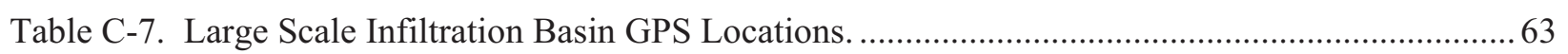

Table C-8. Lincoln Boulevard Borrow Source Disturbed Area GPS Locations....................................... 65

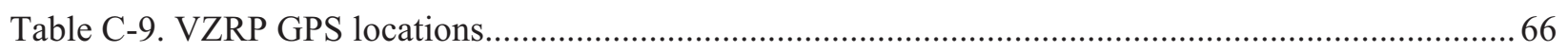




\section{ACRONYMS}

ACOE

BEA

BORAX

CFA

CGP

DOE-ID

EPA

ES\&S

ESRP

$\mathrm{ft}$

FY

GI

GPS

GSS

ICM

ICP

INL

INTEC

ISU

IWP

LTS

MFC

NOAA

NSTR

RRTR

RWMC

SPC

STD

VAM

VSP

VZRP
Army Corp of Engineers

Battelle Energy Alliance, LLC

Boiling Water Reactor Experiment

Central Facilities Area

General Permit for Storm Water Discharge from Construction Activities

U.S. Department of Energy Idaho Operations Office

U.S. Environmental Protection Agency

Environmental Support and Services

Eastern Snake River Plain

feet

Fiscal Year

Geomorphic Investigations

Global Positioning System

Gonzales-Stoller Surveillance, LLC

Interceptor Canal Mound

Idaho Cleanup Project

Idaho National Laboratory

Idaho Nuclear Technology and Engineering Center

Idaho State University

Industrial Waste Pond

Long-term Stewardship Site

Materials and Fuels Complex

National Oceanic and Atmospheric Association

National Security Test Range

Radiological Response Training Range

Radioactive Waste Management Complex

Construction Specification

Standard Deviation

vesicular-arbuscular mycorrhizae

Visual Sample Plan 6.0

Vadose Zone Research Park 


\section{Fiscal Year 2012 Revegetation Assessment}

\section{Introduction}

Revegetation of disturbed sites at the Idaho National Laboratory (INL) is required to comply with some aspects of both federal (7 USC 2814) and state (IDAPA 02.06.22) noxious weed control laws. Revegetation is identified as a method for prevention and/or control of noxious weeds. Executive Order 13112, Invasive Species, also specifies revegetation as a control measure to limit the spread of invasive species. In addition, revegetation may be required by project specific environmental checklists that require projects to complete and verify successful revegetation of disturbed soils.

Battelle Energy Alliance, LLC (BEA) complies with the National Pollutant Discharge Elimination System (40 CFR 122) General Permit for Storm Water Discharges from Construction Activities (CGP) issued by the U.S. Environmental Protection Agency (EPA) in 2012. New projects, disturbing one or more acres of land, require coverage under the 2012 CGP. A Notice of Intent for coverage under the new CGP must be submitted to the EPA at least 14 calendar days prior to earth disturbing activities. The INL Site currently uses the INL Site Storm Water Corridor to determine when a construction activity has the potential to impact "waters of the United States" under the CGP requirements. The INL Storm Water Corridor is defined "as an area that has a reasonable potential to discharge storm water to the Big Lost River."

A letter (Stenzel 2008) was submitted to the U. S. Army Corps of Engineers (ACOE) on May 7 , 2008. The letter requested the ACOE to perform a Jurisdictional Determination concerning the applicability of Section 404 of the Clean Water Act and Sections 9 and 10 of the Rivers and Harbors Act of 1899 for the Big Lost River, Little Lost River, and Birch Creek. The ACOE responded with a letter dated May 26, 2009 (Brochu 2009) that stated "Due to the workload and priorities we are unable to complete your request. If you propose a specific project which may affect wetlands, playas, streams, creeks, or other waters such as the Big Lost River, Little Lost River or Birch Creek we shall reinitiate your request." Therefore, until a specific project is initiated and ACOE performs the Jurisdictional Determination or BEA submits another request, BEA will continue to comply with the CGP requirements.

For the 2012 Revegetation Assessment, two sites were located within the INL Storm Water Corridor. These sites are the Geomorphic Investigations for Flood Bounds (GI) and the Vadose Zone Research Park (VZRP). Eight additional sites not in the INL Storm Water Corridor were also evaluated. These included the Boiling Water Reactor Experiment (BORAX)-V, Central Facilities Area (CFA)-04 Pond Remediation, CFA Former Fire Station II, Large-scale Infiltration Basin, Lincoln Boulevard Borrow Source, Materials and Fuels Complex (MFC) Industrial Waste Pond, MFC Vehicle Barrier Project, and National Security Test Range (NSTR) Project.

A digital camera sampling and analysis method was used to assess specific well sites at the VZRP and disturbed areas at the GI located within the INL Storm Water Corridor. It was also used to assess all other sites except the MFC Vehicle Barrier Project, MFC Industrial Waste Pond, and NSTR. This method was used to quantitatively determine when revegetation of a disturbed area is complete. Visual observations will continue to be used on newly disturbed sites or until the sites appear to be reaching the final stabilization requirement.

Anderson and Shumar (1989) recommended using cover of perennial species as the best quantitative measure for evaluating the success of reclamation plantings, although visual observation of the area may suffice for many projects. They recommended using the point interception frame described by Floyd and Anderson (1987). Digital photography has been shown to be as accurate as traditional point-frame sampling if the information is abstracted from the images using techniques comparable to those used in point sampling. Manually specifying either plant cover of species at a few points on the images is 
equivalent conceptually to the fixed point-frame sampling recommended by Floyd and Anderson (1987) (Booth et. al., 2006 as cited in Schafer 2009).

\subsection{Purpose}

The purpose of this report is to comply with Contract Data Requirements List item number F.24 by providing this revegetation assessment to the Department of Energy, Idaho Operations Office (DOE-ID).

\subsection{Organization}

This report is organized by individual site and provides the following information:

- A historical background summary of each site

- An assessment of background vegetation

- An assessment of the revegetation effort and site stabilization status

- Actions and Resolutions for the site.

\section{Background}

Revegetation efforts for replanting and rebuilding the soil on disturbed land are an ongoing practice at the INL Site, and an annual report of these activities is submitted in accordance with BEA's contract with the DOE-ID. Revegetation sites being assessed for final stabilization in fiscal year (FY) 2012 are listed in Table 1.

Table 1. Sites included in the 2012 revegetation assessment.

\begin{tabular}{l}
\hline \multicolumn{1}{c}{ Site Name } \\
\hline BORAX-V \\
CFA-04 Pond Remediation \\
CFA former Fire Station II \\
Geomorphic Investigations for Flood Bounds (located within INL Storm Water Corridor) \\
Large-scale Infiltration Basin \\
Lincoln Boulevard Borrow Source \\
Materials and Fuels Complex Industrial Waste Pond \\
Materials and Fuels Complex Vehicle Barrier Project \\
National Security Test Range Project Power Pole 179 \\
Vadose Zone Research Park (located within INL Storm Water Corridor) \\
\hline
\end{tabular}

For the GI and VZRP projects, the INL used the definition of final stabilization for arid and semi-arid areas provided by the 2003 CGP. Final stabilization was achieved at these two revegetation sites located within the INL Storm Water Corridor based on this definition. The CGP defines final stabilization for arid and semi-arid areas as follows:

In arid and semi-arid areas only, all soil disturbing activities at the site have been completed and both of the following criteria have been met:

a. Temporary erosion control measures (e.g., degradable rolled erosion control product) are selected, designed, and installed along with an appropriate seed base to provide erosion control for at least three years without active maintenance, 
b. The temporary erosion control measures are selected, designed, and installed to achieve $70 \%$ vegetative cover within three years.

Future projects located within the INL Storm Water Corridor will be evaluated under the 2012 CGP criteria for final stabilization.

Disturbed sites not located within the INL Storm Water Corridor are considered to have reached final stabilization when vegetation within the disturbed area has reached $70 \%$ cover of native, perennial background vegetation.

The location of the INL in the Eastern Snake River Plain (ESRP), including altitude, latitude, and intermountain setting, affects the climate of the Site. Air masses crossing the ESRP have first crossed a mountain barrier and precipitated a large percentage of inherent moisture. Therefore, annual rainfall at the INL is light, and the region is classified as arid to semi-arid (Clawson et. al. 1989).

Vegetation at the INL typically consists of a shrub overstory with a perennial grass and forb understory. Wyoming big sagebrush (Artemisia tridentata subspecies wyomingensis) is the most common shrub. Basin big sagebrush (Artemisia tridentata subspecies tridentata) is dominant or co-dominant with Wyoming big sagebrush on sites having deep soils or accumulations of sand on the surface. Communities dominated by big sagebrush occupy most of the central portions of the INL and most areas included in this assessment. Green rabbitbrush (Chrysothamnus viscidiflorus) is the next most abundant shrub in many of these communities. Other common shrubs include gray rabbitbrush (Ericameria nauseosus), winterfat (Krascheninnikovia lanata), spiny hopsage (Grayia spinosa), prickly phlox (Leptodactylon pungens), broom snakeweed (Gutierrezia sarothrae), and horse-brush (Tetradymia canescens).

The most common native grasses found within sagebrush communities across the INL and in the assessment areas include thickspiked wheatgrass (Elymus lanceolatus), bottlebrush squirreltail (Elymus elymoides), Indian ricegrass (Achnatherum hymenoides), needle-and-thread grass (Hesperostipa comata), and Sandberg bluegrass (Poa secunda). Great Basin wildrye (Leymus cinerus) and western wheatgrass (Pascopyrum smithii) can also be found in localized patches. Bluebunch wheatgrass (Pseudoroegneria spicata) is rare at the lowest elevations but is common at slightly higher elevations to the southwest and along the eastern side of the INL; it is often the dominant grass on alluvial fans and slopes of the buttes and foothills (Anderson, et. al. 1996).

Cheatgrass (Bromus tectorum), an invasive annual species, is also widespread and well established across the INL. Goodrich and Gale (1999) noted that in similar situations, cheatgrass should be recognized as a component of the potential plant community. Gonzales-Stoller Surveillance, LLC (GSS) and Idaho State University (ISU) identified the Bromus tectorum Semi-natural Herbaceous Vegetation and Sisymbrium altissmum-Bromus tectorum Semi-natural Herbaceous Vegetation classes (Shive 2011).

In addition, nearly monotypic stands of crested wheatgrass (Agropyron cristatum) can be found in localized areas across the INL, including several of the sites near MFC included in this assessment. Crested wheatgrass remains productive for more than 30 years, and stand mortality is virtually unknown, except in cases of extreme drought during critical phenological stages (Hardy BBT Limited 1989). Anderson and Marlette (1986) point out that crested wheatgrass may inhibit or preclude the reestablishment of native species on disturbed sites and may become the dominant species. GSS reported that in areas with no anthropogenic influence, crested wheatgrass was found to invade sagebrush stands and out-compete the native plant species (Shive 2011). GSS and ISU identified a crested wheat vegetation class at the INL as "Agropyron cristatum (Agropyron desertorum) Semi-natural Herbaceous Vegetation" (Shive 2011).

Big sagebrush is the climax species on most of its range (Eddleman and Doescher 1978, Jensen at. al. 1988). While seedling establishment may begin immediately following a disturbance, it usually takes a decade or more before big sagebrush dominates a site (Welch and Criddle 2003), though some researchers argue 25-45 years is typical (Watts and Wambolt 1996, Wambolt et. al. 2001). Because roots of big sagebrush species, particularly Wyoming big sagebrush, are infected with the vesicular-arbuscular mycorrhizae (VAM) Glomus microcarpus and Gigaspora spp. (Bethlenfalvay and Dakessian 1984; 
Doerr, et. al. 1971; Hurley and Wicklow-Howard 1986) and VAM associated with Wyoming big sagebrush are killed by heating or chemical alteration of the soil, VAM, and thus sagebrush, take several years to recolonize after soil-altering disturbance (Wicklow-Howard 1989).

Absence of VAM probably inhibits Wyoming big sagebrush establishment on disturbed soils. For example, 2.5 years after restoration work, VAM had not yet colonized a coal-mined site in south-central Wyoming even though stockpiled topsoil was replaced. When VAM-infected and noninfected Wyoming big sagebrush seedlings were transplanted on the site, there was no significant difference in growth between the 2 groups: both showed poor establishment. However, in the greenhouse, biomass gain of the infected group was significantly greater (about 1.5 times more, $\mathrm{p}=0.05$ ) compared to the uninfected group. This suggests that on the disturbed site, VAM were unable to survive anywhere but inside Wyoming big sagebrush roots, and establishment of VAM and host Wyoming big sagebrush probably will not occur until the chemistry of lower soil horizons changes with succession (Stahl et. al. 1988).

None of the subspecies of big sagebrush resprout after fire or other disturbance, and prior to reestablishment, big sagebrush communities are mostly populated with associated grasses (Sheehy and Winward 1981). As expected, shrub cover on disturbed sites across the INL is much lower than that found on undisturbed sites, and grasses associated with big sagebrush communities account for most of the perennial vegetation found on disturbed sites included in this assessment.

National Oceanic and Atmospheric Administration (NOAA) Idaho National Laboratory Mesonet data at CFA indicate that precipitation during the fall of 2011 and spring of 2012 was below average. Plant growth was not as vigorous compared to the last several years.

\section{Site Revegetation Assessment Summary}

The State of Idaho Department of Environmental Quality's "Catalog of Stormwater Best Management Practices for Idaho Cities and Counties" notes that construction activities should maintain and preserve the vegetative canopy. In addition, Minnesota Pollution Control Agency and Environmental Protection Agency Region V developed stormwater guidance for small construction operators to use canopy cover when determining compliance with the $70 \%$ final stabilization requirement. Based on this information, canopy cover is used to determine final stabilization of revegetation sites at the INL.

Canopy cover is the area of the ground surface spanned by the canopy of the plant, and is used because it determines the underlying plant community. A high percentage of plant cover generally increases the soil infiltration rate, thereby reducing runoff and soil erosion. Plant cover also reduces wind erosion.

For specific well sites at the VZRP located within the Stormwater Corridor, two trenches at the GI Project, BORAX-V, CFA-04 Pond, CFA Former Fire Station 2, Large Scale Infiltration Basin, and the Lincoln Boulevard Borrow Source, Environmental Support and Services (ES\&S) personnel performed digital camera sampling and analysis as described in "Establishing Revegetation Performance Measures at INL" (Schafer 2009) to determine canopy cover on disturbed sites of the assessment area. Invasive and annual species were not included when determining percent cover. Where digital camera sampling was performed, resulting transect quadrate photos were interpreted using the program SamplePoint (discussed in Schafer, 2009), and were categorized as being grass, forb, shrub, cactus, litter, soil, rock, unknown, or annual. Because the 2012 CGP requires the establishment of perennial vegetation, annual species such as cheat grass, desert alyssum (Alyssum desertorum), and mustard species were classified in the same category as invasive species and not used to calculate total cover.

For each location, results are summarized as percent by category and percent by category within the background data for each site. In addition to the categories previously listed, the tables include a category for "\% Cover" computed as the total cover percent as the sum of the means for the percentages for grass, forb, shrub, and cactus. Invasive and annual species, rock, soil, litter, and unknown species were not considered in the percent cover calculations. These summary tables are included in Appendix A. Appendix C contains Global Positioning System (GPS) coordinates for transect photos. For sites where 
digital camera sampling was not conducted, this report relies on visual observations. Visual observations were used to evaluate these sites.

Statistical analysis was performed using SigmaStat 3.0. A Mann-Whitney U- test was used on sample locations that showed a non-parametric distribution. SigmaStat is able to determine whether or not the data is normally distributed, and in cases where the distribution was normal, a paired t-test was performed. The t-test is a type of parametric test. This means that the test itself is based upon certain assumptions about the data. In particular, the values are assumed to approximate a normal distribution, and the standard deviations of both sets of numbers are assumed to be equal.

For many types of data, non-parametric tests are also available. These do not rely upon the data conforming to any particular distribution; that is, they are "robust". The Mann-Whitney U-test is appropriate for comparing two sets of numbers to see whether or not they are different.

Maps of former Long Term Stewardship (LTS) Program sites included in this report were taken from the Weed Control and Revegetation Report for Fiscal Year 2006 (ICP 2007) to show site locations and areas recommended for weed control and are representative of conditions the last time the sites were assessed in 2006.

\section{BORAX-V}

During the operational history of INL, numerous revegetation sites have been created and placed into the Long Term Stewardship (LTS) Program as a result of the Idaho Cleanup Project (ICP) activities and other programs . During these activities, the contaminated surface and subsurface soil was removed, and the clean soil that replaced the contaminated soil at many sites was either sterile or otherwise unsuitable for plant growth (e.g., too much gravel, too many rocks, and/or littered with debris).

The BORAX-V site is a former LTS site located in the southwest portion of the INL, north and east of Radioactive Waste Management Complex (RWMC) (Figure 1). The Weed Control and Revegetation Report for Fiscal Year 2006 (ICP 2007) recommended that this site continue to be monitored and weeds continued to be controlled until the disturbed area meets $70 \%$ cover of the background species.

\subsection{Site Background Conditions}

The most recent assessment of the revegetation site (ICP 2007) noted the following:

"This site looks better every year. The entire site has numerous forbs (i.e., curlycup gumweed (Grindelia squarrosa), globemallow (Sphaeralcea ambigua), purple aster (Symphyotrichum patens), flax (Linum perenne) and desert dusty maiden (Chaenactis macrantha)). The entire site has native grasses (i.e., Sandburg's bluegrass and Indian ricegrass). The entire site has some gray rabbitbrush and green rabbitbrush. The west side of the site contains additional native grasses (i.e., ryegrass, bottlebrush squirreltail and several wheatgrasses) as well as cheatgrass and crested wheatgrass. The west side also contains hoary aster (Dieteria canescens), yellow sweet clover (Melilotis indicus), grey rabbitbrush, green rabbitbrush and abundant kochia (Kochia scoparia). Sandberg's bluegrass is also abundant. A few small bare patches have kochia, Russian thistle (Salsola kali) and halogeton (Halogeton glomeratus). The road and perimeter of the site have several wheatgrasses, globemallow, sagebrush, flax, curlycup gumweed, ryegrass, green rabbitbrush and grey rabbitbrush."

It was further recommended that bare and gravelly areas of the site be reseeded and that monitoring occur until the disturbed area meets $70 \%$ cover of the background vegetation.

Background vegetation is composed of sagebrush, rabbitbrush, crested wheatgrass, buckwheat, other wheatgrasses, bottlebrush squirreltail, rye grass, Indian ricegrass, some cheatgrass, and prickly pear cactus (Opuntia polyacantha). 


\subsection{Site Assessment}

The site is separated into an eastern and western half by an access road. The road has been barricaded, but it is evident from the state of the road, lack of vegetation, and observable vehicle tracks around the barricade that the road is still used.

A background transect was placed south of the disturbed area on the east side of the old access road. The disturbed area transects were placed on parallel to the road on the western side of the disturbed area and in a diagonal on the east side of the road as shown in Figure 2. Transects were located in an attempt to capture areas bare of vegetation. Table C-1 lists GPS coordinates for plots at this location. Figure B-1 shows a typical background vegetation plot.

Mean perennial cover of the disturbed area at BORAX-V is $105.5 \%$ of background (Table A-1). There is no statistically significant difference between total cover on disturbed plots versus background plots $(\mathrm{p}=0.563)$. Figure B-2 shows a representative plot of the disturbed area.

\subsection{Actions and Resolutions}

The disturbed area has achieved final stabilization. 


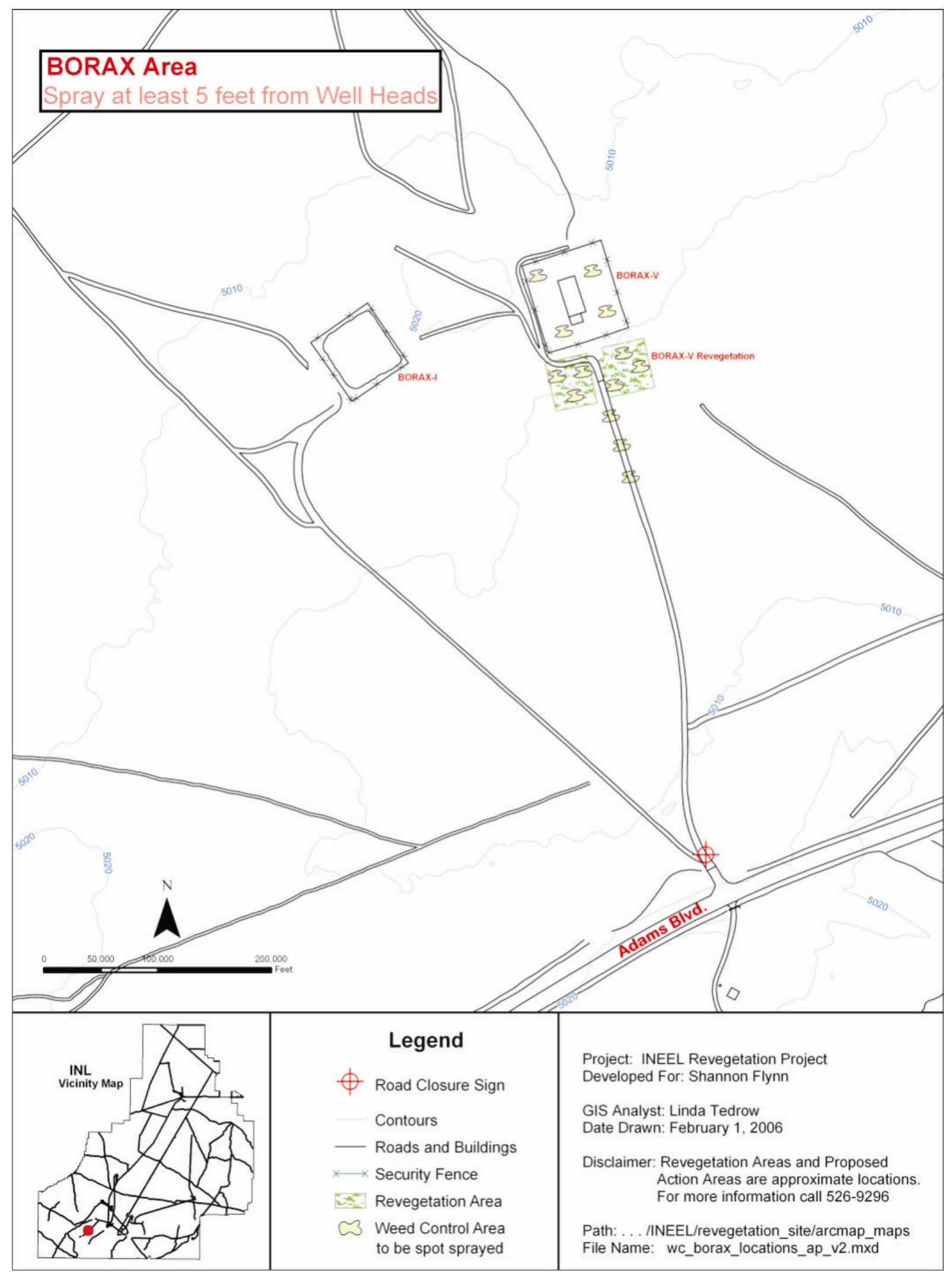

Figure 1. Map of the BORAX-V Revegetation Area. 


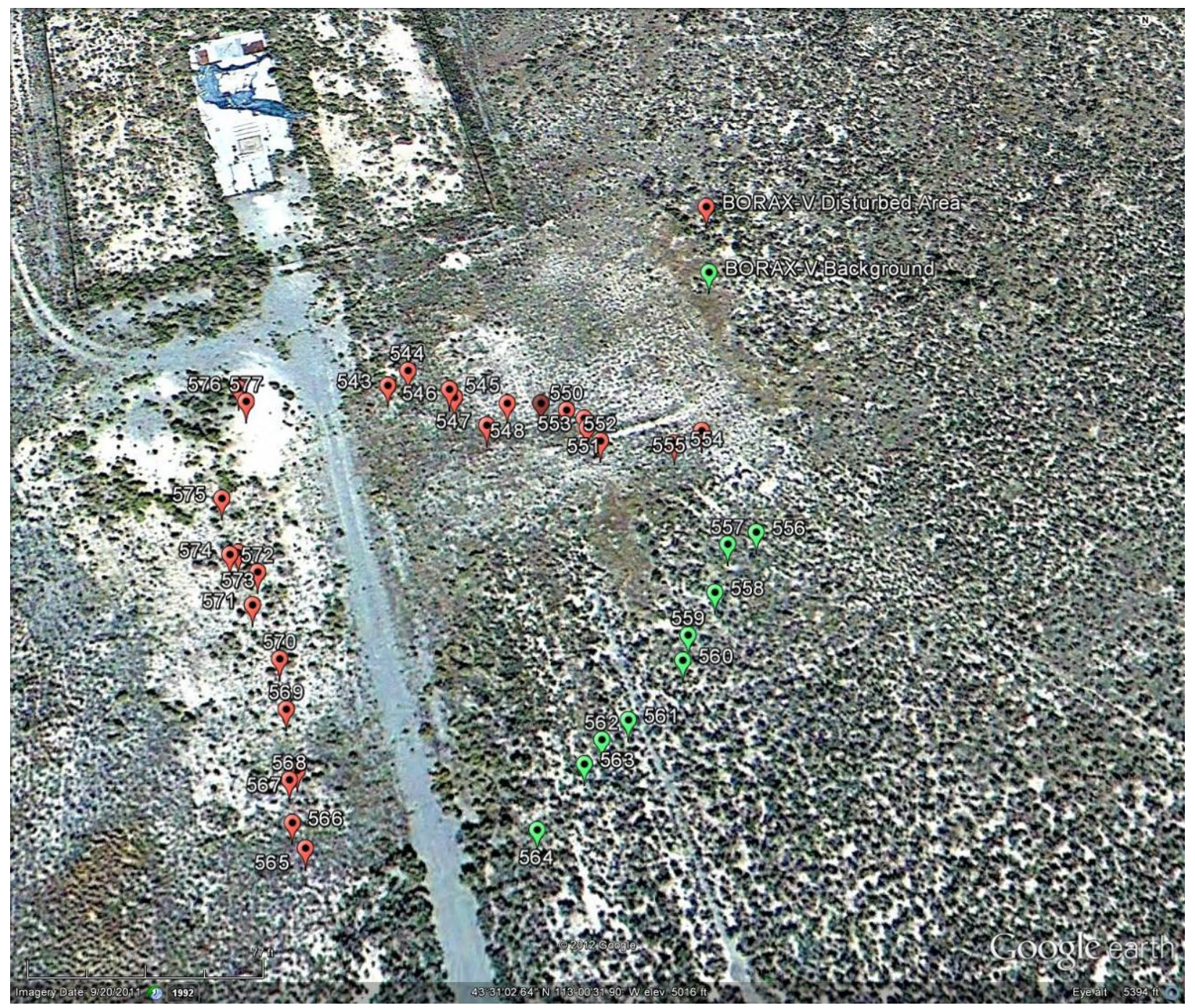

Figure 2. BORAX-V Transect Locations.

\section{CFA-04 Pond Remediation}

The CFA-04 Pond remediation site is also an LTS site. It is located south of CFA and south of building CFA-674 (Figure 3). The Weed Control and Revegetation Report for Fiscal Year 2006 (ICP January 2007) projected the site to achieve $70 \%$ cover within 5 years.

\subsection{Site Background Conditions}

The 2006 assessment noted the following:

"The site looks worse than last year, especially on the northeast side. The woodchips on the north side are thick. There is a large crop of kochia with some halogeton, purple mustard, and Russian thistle on the north end. There are also some great patches of native thickspike and western wheatgrasses. There are numerous large tumble mustards (Sisymbrium altissimum) and cheatgrass is common. The bottom of the pit looks great for grass coverage but it looks somewhat unhealthy. The east entrance road to the site has mostly Russian thistle and kochia with some halogeton, yellow sweetclover, native wheatgrasses and mustards. There are shrubs, both sagebrush and rabbitbrush, on the perimeter. The perimeter on the north side of the site also contains crested wheatgrass. The west side of the site also has Indian ricegrass and other wheatgrasses. The south side of the site has ryegrass." 
The 2006 assessment also noted that activities associated with small mammal trappings was having a negative effect on the revegetation effort and it was recommended to discontinue the activity.

Background vegetation is composed of sagebrush, rabbitbrush, crested wheatgrass, buckwheat, other wheatgrasses, squirreltail, rye grass, and Indian ricegrass.

\subsection{Site Assessment}

Vegetation appears to be uniformly distributed throughout the disturbed area, and large bare patches were not observed. Thickspike and western wheatgrass were the most common native grasses encountered during this assessment. Transects were located as shown in Figure 4. Table C-2 lists GPS coordinates for plots at this location. Figure B-3 shows a typical background vegetation plot.

Mean perennial cover of the disturbed area at the CFA-04 Pond remediation site is $88.2 \%$ (Table A-2) of background, and there was no statistically significant difference between mean cover values of the disturbed area and background $(p=0.721)$. Figure B-4 shows vegetation typically encountered in the disturbed area.

\subsection{Actions and Resolutions}

The disturbed area has achieved final stabilization, and it is recommended that it no longer be monitored and included in future assessments. 


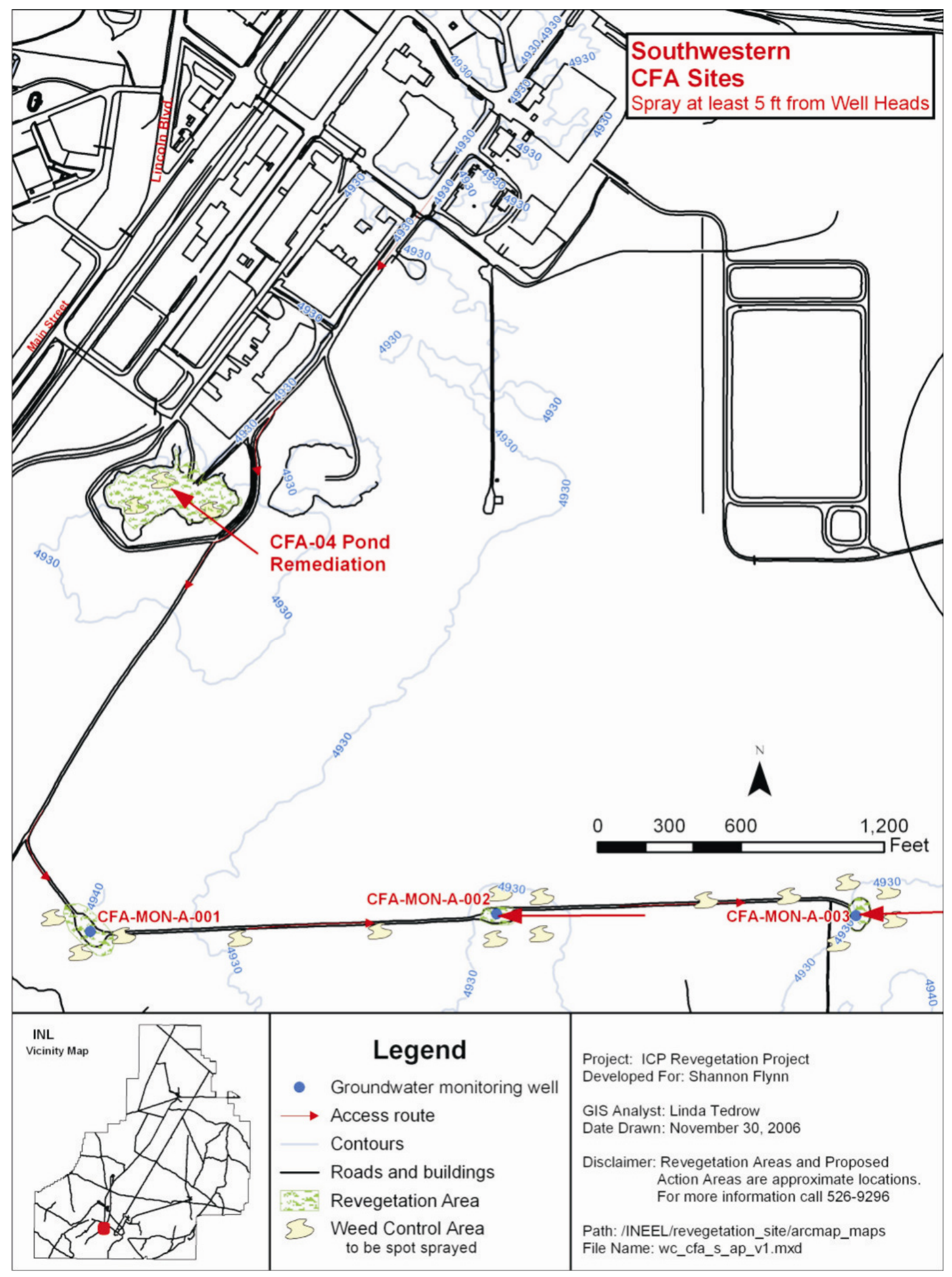

Figure 3. Map of the CFA-04 Pond Remediation Revegetation Area. 


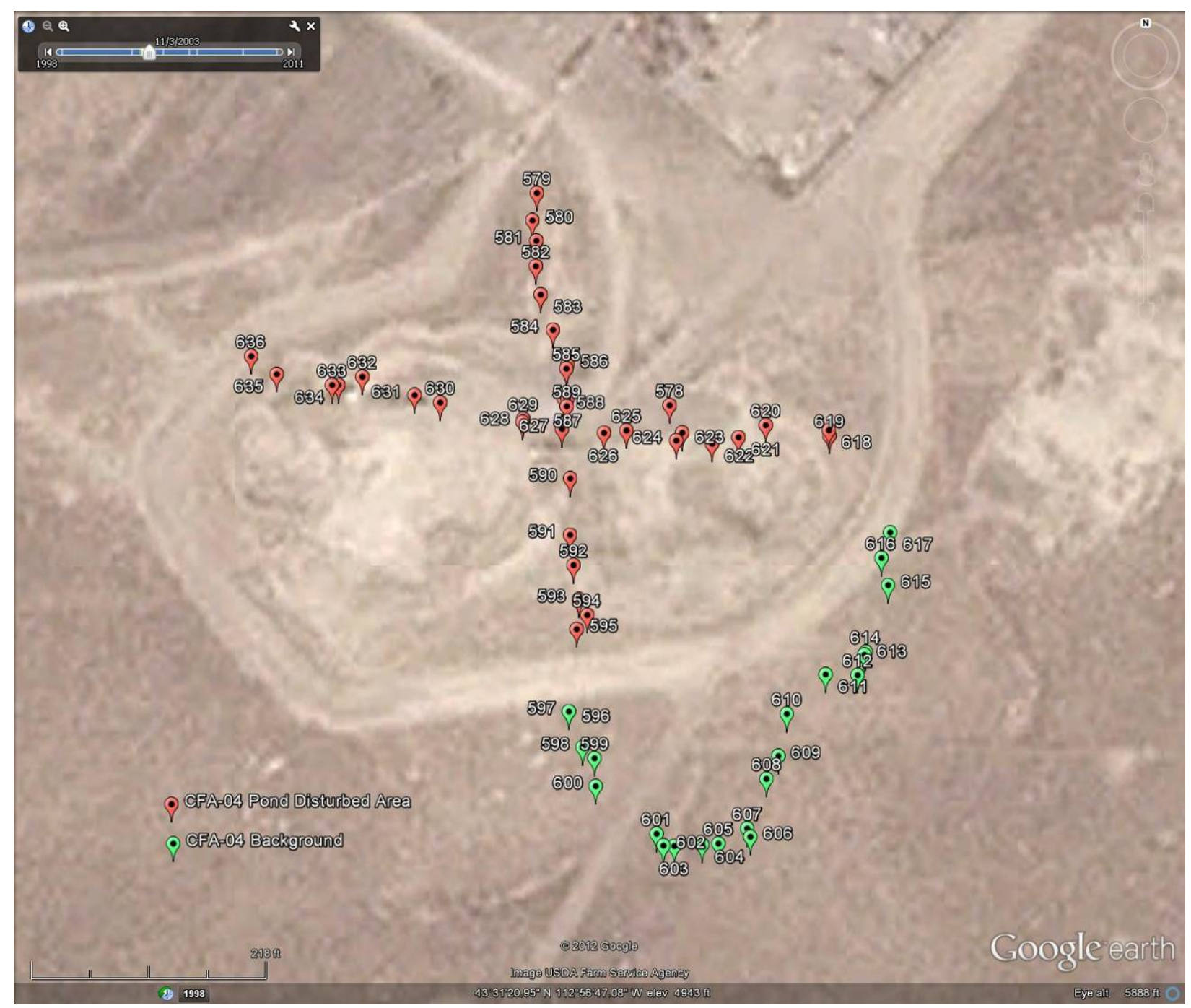

Figure 4. CFA-04 Pond Remediation Transect Locations.

\section{CFA Former Fire Station 2}

The CFA Former Fire Station 2 is also an LTS site located along Lincoln Boulevard, just south of mile marker 5, approximately 4 miles north of CFA (Figure 5). On November 16, 2005, bare areas, approximately $50 \mathrm{ft}$ long by $20 \mathrm{ft}$ wide (five drill lines each) on the south and east sides of the site were reseeded. Green rabbitbrush is the predominate shrub in the disturbed area. The disturbed area is surrounded by a crested wheatgrass monoculture, and crested wheatgrass is the most common grass in the disturbed area.

\subsection{Site Background Conditions}

The 2006 assessment stated that crested wheatgrass was the dominant species, and noted the western half of the site had been mowed. Field bindweed (Convolvus arvensis) and hoary cress (Cardaria draba) were noxious weeds found on the site. Desert alyssum, Russian thistle, and halogeton were common.

In 2012, green rabbitbrush was the predominate shrub in the disturbed area. The disturbed area is surrounded by a crested wheatgrass monoculture, and crested wheatgrass is the most common grass in the disturbed area. No mowing had occurred at the time of this assessment. Minor amounts of desert alyssum (Alyssum desertorum) and halogeton were noted. Background vegetation is composed mainly of crested wheatgrass. 


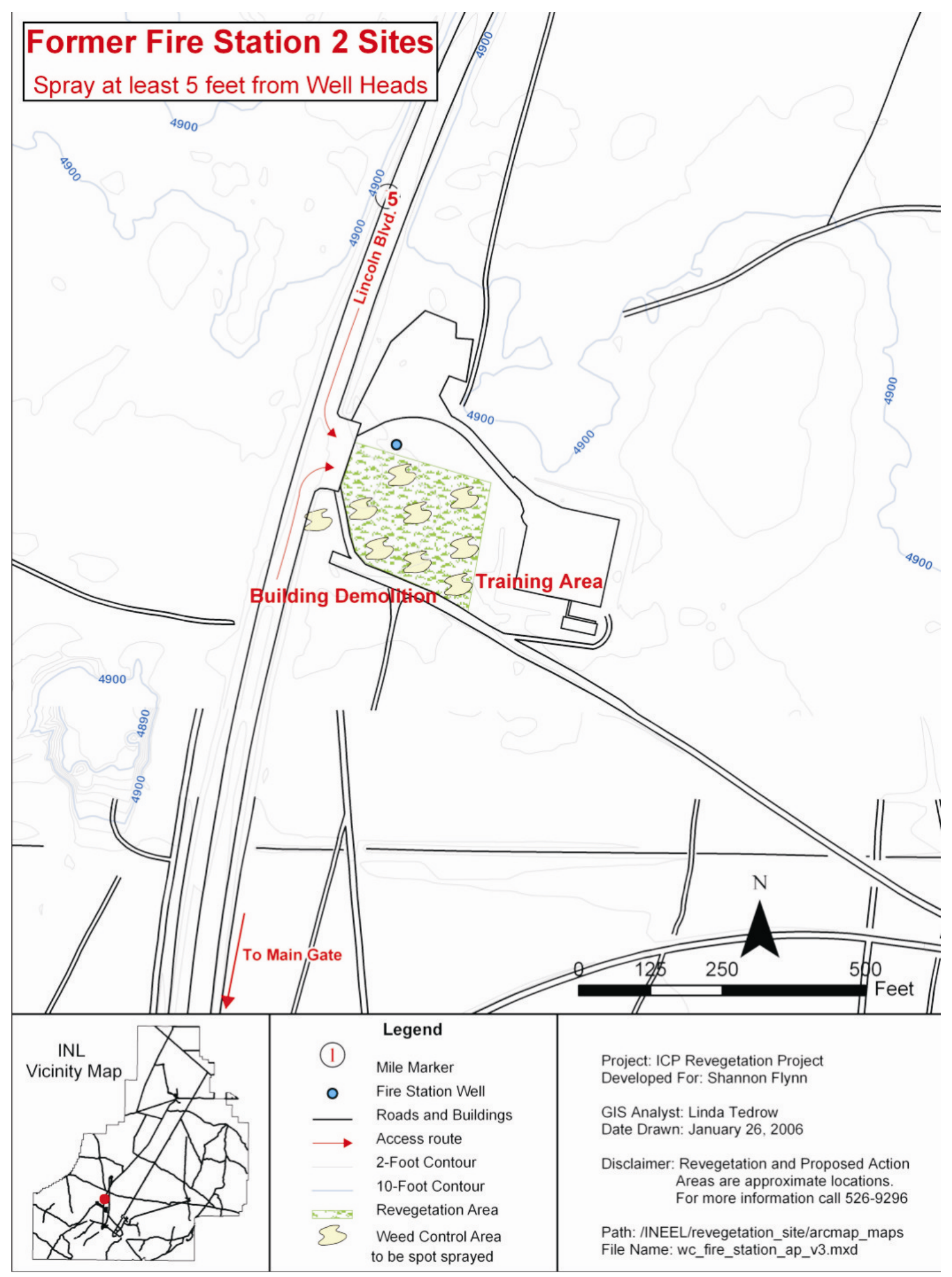

Figure 5. Map of the CFA Former Fire Station 2 Revegetation Site. 


\subsection{Site Assessment}

Vegetation appears to be uniformly distributed throughout the disturbed area, but a small bare area is present near the center of the site. Wood chips in this area are fairly thick. The assessment of the disturbed area was limited to the area with wood chips since distinguishing the rest of the disturbed area from the background vegetation was difficult. The area assessed appears to be the area reseeded in 2005 . Transects were located as shown in Figure 6. One transect was placed running east to west through the center of the disturbed site and another running north to south. Table C-3 lists GPS coordinates for plots at this location. Figure B-5 shows a typical background vegetation plot. A Background transect was placed south of the site as shown in Figure 7.

Mean perennial cover of the disturbed area at the CFA Former Fire Station 2 site is $80.0 \%$ (Table A-3) of background, and there was no statistically significant difference between mean cover values of the disturbed area and background $(\mathrm{p}=0.543)$. Figure B-6 shows vegetation typically encountered in the disturbed area.

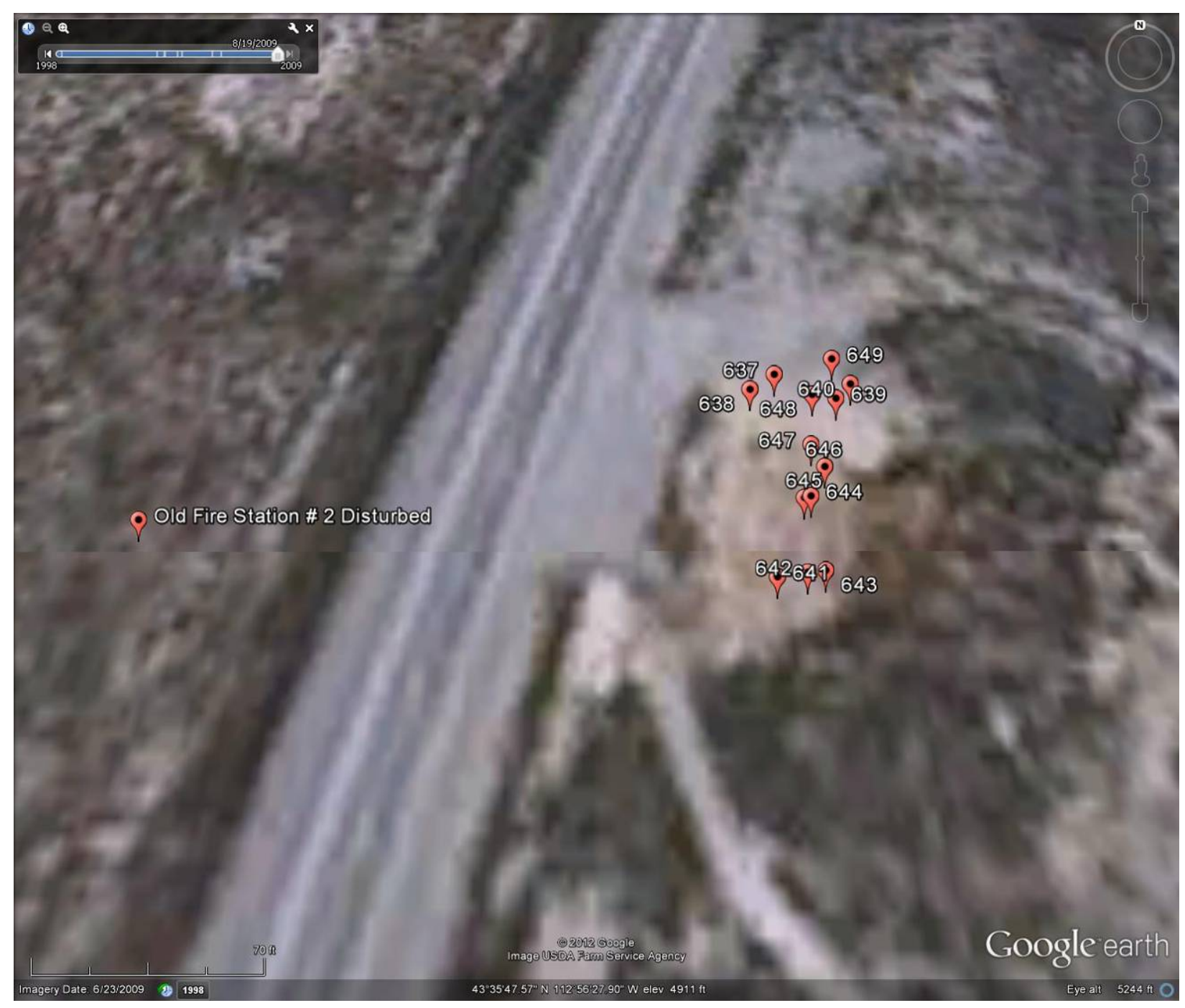

Figure 6. CFA Former Fire Station 2 Disturbed Area Transects. 


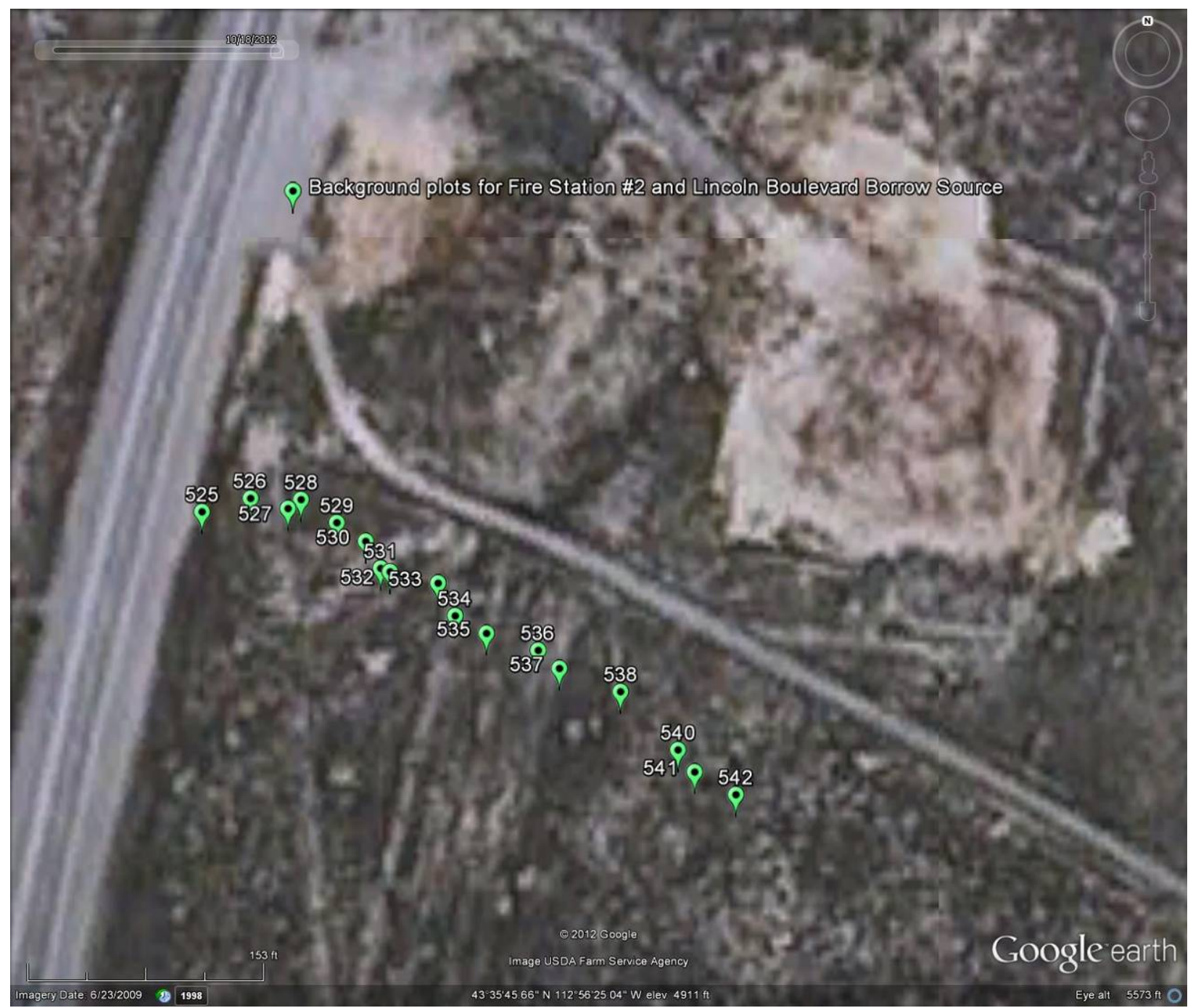

Figure 7. CFA Former Fire Station 2 Background Transect.

\subsection{Actions and Resolutions}

The disturbed area has achieved final stabilization and will no longer be included in future assessments.

\section{Geomorphic Investigations for Flood Bounds}

During the Geomorphic Investigations (GI) Project, eight trenches near the Big Lost River on the INL Site were excavated for the purpose of collecting soil and geomorphic and stratigraphic data of the Holocene and Pleistocene deposits for evaluating historical river and flood information (Figure 8). The project began in May 2002 and continued through October 2002. The trenches ranged from 60 to 900 feet in length. 


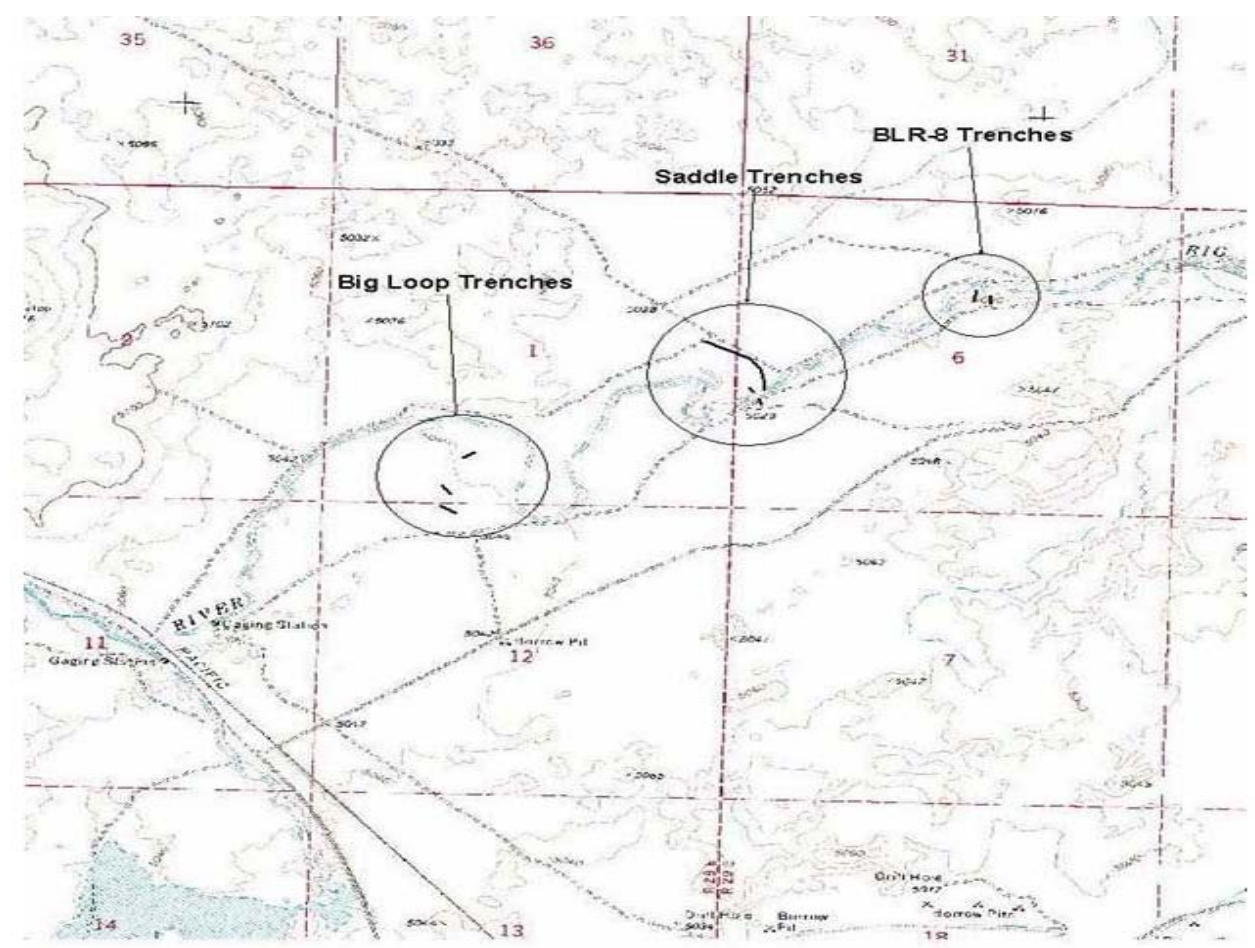

Figure 8. Map of the Geomorphic Investigations Project

The S. M. Stoller Corporation backfilled, contoured, seeded, and installed new silt fencing in September 2007. The seed mix included Wyoming big sagebrush, thickspiked wheatgrass, Indian ricegrass, needle and thread grass, and bottlebrush squirreltail. Approximately 1,000 Wyoming big sagebrush seedlings were also planted. Electric fences were placed around the trenches located on the west side of the Big Lost River, however, these fences were removed in 2009.

In 2009, the erosion fences (silt fences) installed at the ends of the BLR-8 and Saddle Trenches were removed and replaced with straw wattles. The straw wattles appear to be more durable than the silt fences while serving the same purpose. In addition, it was determined that silt fences were no longer required for the Big Loop Trenches because of the distance from the Big lost River and the level topography where the trenches are located.

\subsection{Site Background Conditions}

The GI Project is located within a sagebrush steppe community. Wyoming big sagebrush is dominant on undisturbed sites in this area, although other species of big sagebrush are co-dominant. Bottlebrush squirreltail is the dominant grass. Other plant species observed throughout the background include: tapertip hawksbeard (Crepis acuminata), cushion buckwheat (Eriogonum ovalifolium), shaggy fleabane (Erigeron pumilus), bluebunch wheatgrass, green rabbitbrush, and Hood's phlox (Phlox hoodii).

Only the Big Loop Trenches are located within the undisturbed sagebrush steppe community. Both the BLR-8 and Saddle Trenches are located within the Tin Cup Fire scar (Forman 2010).

Cheatgrass is present in the vegetation communities that surround all of the trenches.

In 2011, digital camera sampling was conducted on the BLR-8 trenches, and it was noted that final stabilization had been achieved. In 2012, visual assessments were conducted on the long Saddle Trench and the middle and northeast Big Loop Trenches. Cheat grass and other annuals were prevalent and the areas did appear to meet the $70 \%$ criteria for final stabilization. Digital Camera sampling was performed on the southwest Big Loop and the north and south Saddle Trenches. 


\subsection{Site Assessment}

The S.M. Stoller Corporation previously monitored the GI Project revegetation progress (Forman 2010). Gonzales-Stoller Surveillance, LLC (GSS) replaced the S.M. Stoller Corporation. Correspondence from GSS personnel indicated they would no longer be monitoring or performing any revegetation activities at the GI Project (Forman 2011).

For this assessment, digital camera sampling was performed on the remaining trenches that had not achieved final stabilization, e.g. the southwest Big Loop trench and the north and South Saddle trenches.

\subsubsection{Saddle Trenches}

Perennial grasses observed within the disturbed area include bottlebrush squirreltail, needle and thread grass, Indian ricegrass, and western wheatgrass. Wyoming big sagebrush and green rabbitbrush plants were also present.

Disturbed area transects were located as shown in Figure 9, and GPS locations are included in Table C-4. Disturbed area transects were run down the middle of the trenches parallel to the long axis. Figure 10 shows the location of the background transect for trenches associated with the GI project. Table C-6 contains GPS locations for the background vegetation.

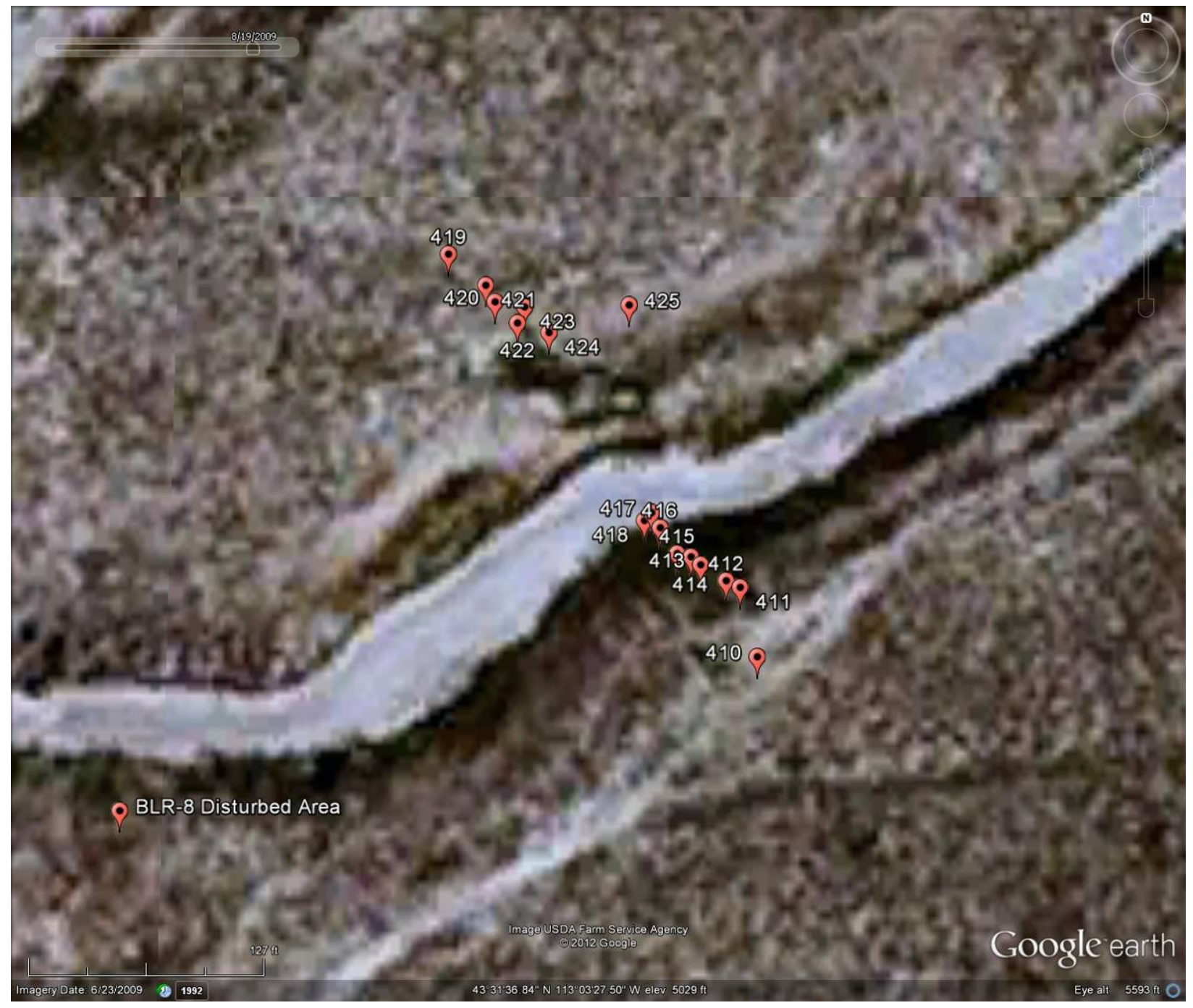

Figure 9. North and South Saddle Trenches Disturbed Area Transects. 


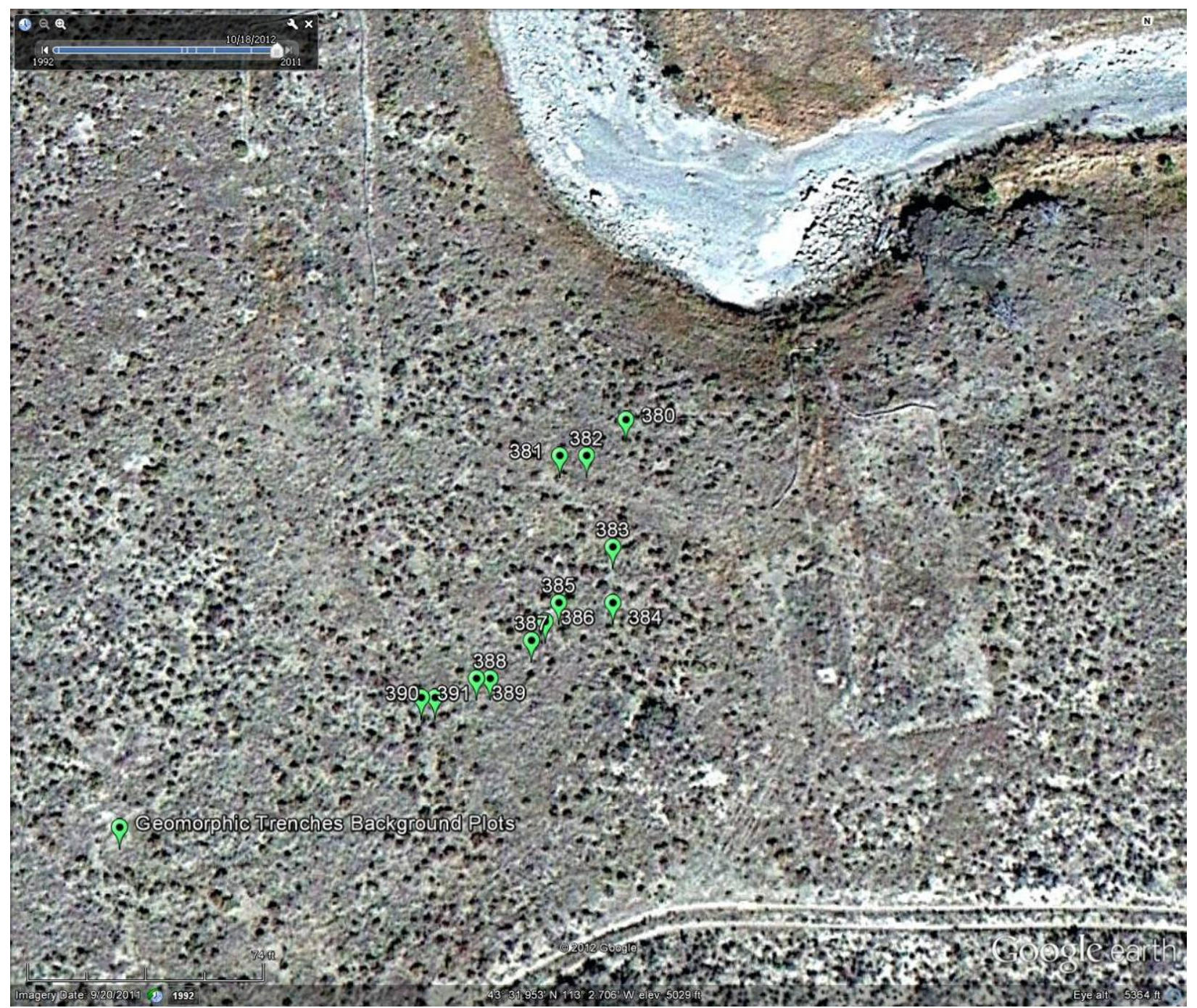

Figure 10. Geomorphic Investigations for Flood Bounds Background Area Transect.

Cheatgrass is prevalent in both trenches. In the north trench, needle and thread grass, bottlebrush squirreltail, and Indian ricegrass plants were observed. Other species identified were Wyoming big sagebrush, green rabbitbrush, orange globemallow (Sphaeralcea munroana), and western tansymustard (Descurainia pinnata), though mustard species were rare compared to previous years. Cover in disturbed area of the north trench has reached $40.5 \%$ of background (Table A-4) and there was no statistically significant difference between cover values for the disturbed area versus background $(\mathrm{p}=0.366)$.

Perennial grasses in the South trench included western wheatgrass, needle and thread grass, bottlebrush squirreltail, and Indian ricegrass. Orange globemallow and silvery lupine (Lupinus argenteus) were also observed. Cover in the disturbed area is $54.3 \%$ of background (Table A-5) and there was a statistically significant difference in total mean cover between background and the disturbed area $(\mathrm{p}=0.020)$.

Figure B-7 is a plot representative of background vegetation for the trenches associated with the Geomorphic Investigations for Flood Bounds . Figures B-8 and B-9 represent plots typically found on the north and south Saddle trenches respectively. 


\subsubsection{Southwest Big Loop Trench}

Perennial grasses observed within the disturbed area of the southwest Big Loop Trench included: bottlebrush squirreltail, needle and thread grass, Sandberg bluegrass, and thickspiked wheatgrass. Sandberg bluegrass appeared to be the most common perennial grass observed. Wyoming big sagebrush plants and silvery lupine were also observed.

The southwest Big Loop Trench is dominated by cheatgrass. Forbs observed included: silvery lupine and shaggy fleabane. Perennial grasses included bottlebrush squirreltail, Sandberg bluegrass, and thickspiked wheatgrass. Wyoming big sagebrush plants were also found on this site.

The background transect for this location is the same as that used for the Saddle Trenches as shown in Figure 10. Disturbed area transects were placed as shown in Figure 11, and GPS locations are included in table C-5.

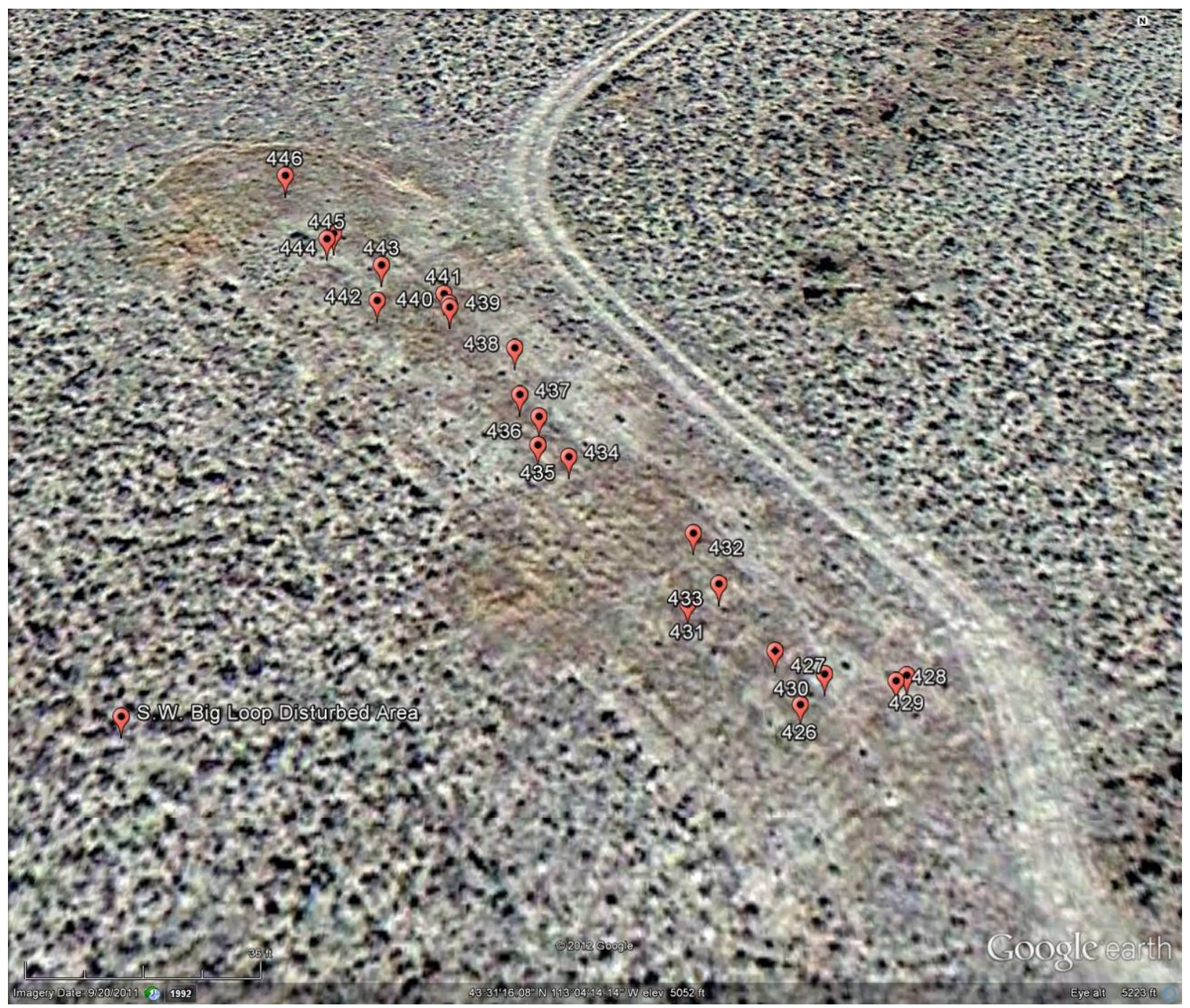

Figure 11. Southwest Big Loop Trench Disturbed Area Transect.

Cover in the disturbed area is $13.1 \%$ of background (Table A-6) and there was a statistically significant difference for cover in the disturbed plots versus background $(p=<0.001)$ which is likely due to the high amount of cheatgrass in the disturbed area (annual species in the disturbed area are $939.9 \%$ of background levels).

Figure B-10 is representative of plots found on the southwest Big Loop trench. 


\subsection{Actions and Resolutions}

In 2012, Russian thistle was not observed at the GI Project. Western tansymustard and Jim Hill tumble mustard populations were light. Wyoming big sagebrush and green rabbit brush, where it occurred, showed good growth. Cheatgrass was present at all of the trenches and was the dominant grass species at all but the BLR-8 trenches.

A 20-year study in southern Idaho showed succession on former big sagebrush steppe was initially dominated by Russian-thistle, Jim Hill tumble mustard, and western tansymustard. An increase in cheatgrass and bottlebrush squirreltail followed; after that, there was a temporary increase in mustards and a decrease in Russian-thistle. The community eventually stabilized as a cheatgrass-bottlebrush squirreltail cover type (Hironaka and Tisdale 1963). Brandt and Rickard (1994) reported similar results, where tumble mustard codominated recently disturbed sites along with Russian-thistle, prickly-lettuce (Lactuca serriola), and bur ragweed (Ambrosia acanthicarpa). Cheatgrass dominated slightly older seres.

Some of these communities dominated by annuals may be stable (Hironaka and Tisdale 1963). Cline and Rickard (1973) state that on the Atomic Energy Commission's Hanford Reservation in Washington, some areas have supported cheatgrass-tumble mustard-tansymustard communities for 30 or more years.

The concept of potential natural communities based only on native species is seriously challenged by cheatgrass. Where cheatgrass is highly adapted, it might have to be recognized as a component of the potential plant community (Goodrich and Gale 1999). In these situations, cheatgrass may remain the de facto climax dominant, regardless of site potential.

Cheatgrass maintains its dominance on many sites by adaptations that facilitate early and rapid growth, including a type of carbohydrate metabolism that permits growth at relatively low temperatures (Chatterton 1994). Because cheatgrass can commence growth and deplete soil moisture before native plants break dormancy, it gains a competitive advantage in cold, semiarid environments (Harris 1967). This is evidenced by greater physiological stress and reduced total root length measured in perennial shrubs and grasses growing with cheatgrass than in plants growing without cheatgrass as a neighbor (Melgoza and Nowack 1991, Melgoza et. al. 1990, Walker and Smith 1197). Cheatgrass also has greater top-growth yields per unit water used compared to summer-growing perennial grasses. This high wateruse efficiency is partly due to early season growth, when transpiration rates are low (Hironaka 1961, Hulbert 1955).

When there is a lack of native annual grasses, cheatgrass fills that niche, and has truncated succession on many sites (Daubenmire 1970, Franklin and Dyrness 1973). Results presented by Young and Evans (1973) suggest that as long as there is a seed source and a suitable seedbed, cheatgrass will dominate on big sagebrush sites after removal of shrub overstory. They did not encounter an assemblage of native annual plants that was capable of preventing cheatgrass dominance on big sagebrush sites.

Because cheatgrass is very persistent once it becomes established, eradication of large infestations is not usually a reasonable goal. The extent to which cheatgrass dominates a plant community greatly determines the appropriate suppression strategy (McIver and Starr 2001, Mosely et.al. 1999), and cheatgrass response to management options is very site specific (Harris and Goebel 1976, Young and Allen 1997). Effective control of cheatgrass requires 1) eliminating live plants, 2) preventing seed formation, and 3) controlling seed germination and emerging seedlings (Monsen 1994). In plant communities where cheatgrass is present but herbaceous perennials remain abundant, cheatgrass control measures should include the needs of the perennial plants. Control without replacement by desirable perennials will likely result in the reestablishment of cheatgrass or some other undesirable species (Mosely et. al. 1999). 
It is inappropriate to manage cheatgrass ranges as if they were perennial grass-dominated ranges (Young 1991). Large areas that are mostly devoid of perennials and have fire-free intervals of 5 or fewer years have probably crossed a threshold, and the cheatgrass community probably represents a relatively stable "steady state" (Laycock 1991, Mosely et. al. 1999), such as exists on many depleted sites within Wyoming big sagebrush habitat types of the Snake River Plain and other portions of the Columbia River Basin (Mosely et. al. 1999). Some authors suggest that it may be best to reclassify these communities as annual grasslands, and manage them accordingly (Vallentine and Stevens 1994, Young et. al. 1987).

The Trenches were evaluated in accordance with the 2003 CGP criteria that states:

The In arid and semi-arid areas only, all soil disturbing activities at the site have been completed and both of the following criteria have been met:

A. a. Temporary erosion control measures (e.g., degradable rolled erosion control product) were selected, designed, and installed along with an appropriate seed base to provide erosion control for at least three years without active maintenance,

b. The temporary erosion control measures were selected, designed, and installed to achieve $70 \%$ vegetative coverage within three years.

It was determined the above criteria was satisfied since an appropriate seed mix was selected and used and appropriate erosion controls were selected, designed and installed to provide erosion control for at least 3 years without active maintenance. The temporary erosion control measures were selected, designed, and installed to achieve $70 \%$ vegetative coverage within 3 years.

A vegetative cover greater than $70 \%$ (including annual and perennial species) was achieved on all of the Trenches,

The intent of the 2003 CGP was to reduce erosion and sedimentation. Although several Trenches have significant annual species (cheatgrass), the sites are considered stable and to have met the intent of the CGP.

A Notice of Termination from the CGP requirements was submitted by BEA (Stenzel 2012) and the Department of Energy Idaho Operations (Perkins 2012) to the EPA on June 19, 2012. The Department of Energy Idaho Operations Office received a letter (EPA 2012) from the EPA dated July 16, 2012 stating that the coverage was terminated as of midnight July 16, 2012. Battelle Energy Alliance, LLC has not yet received a letter. However, the EPA's NOI Processing Center has indicated to BEA personnel, that the request was received and would be processed as soon as their system was operational.

However, while the disturbed locations at the GI Project have met the CGP requirements, they have not achieved the $70 \%$ cover of native perennial background final stabilization criteria used across the INL. Because succession in areas invaded by cheatgrass is slow, and at this time it is not practical or economical to disturb soil and revegetate the area again, it is recommended that the disturbed areas of the GI Project be visually evaluated every three to five years until they appear to be reaching the criteria for final stabilization. BEA should continue to explore and evaluate technologies and relevant scientific information regarding the eradication of cheatgrass that may assist these areas in achieving $70 \%$ cover of native perennial background vegetation.

\section{Large Scale Infiltration Basin}

The Large Scale Infiltration Basin is also an LTS site located about 0.9 miles south of the RWMC (Figure 12). The Weed Control and Revegetation Report for Fiscal Year 2006 (ICP January 2007)

recommended that the site be monitored until the disturbed area meets $70 \%$ cover of background. The 
site is now part of the Radiological Response Training Range (RRTR). Vehicle traffic is allowed on the disturbed area as part of training exercises, and vehicle tracks were observed within the basin.

\subsection{Site Background Conditions}

The Large Scale Infiltration Basin is located within a sagebrush steppe community. Wyoming big sagebrush is dominant on undisturbed sites in this area, although other species of big sagebrush also occur. Plant species observed throughout the background include: tapertip hawksbeard, cushion buckwheat, bluebunch wheatgrass, Indian ricegrass, needle and thread grass, bottlebrush squirrel tail, green rabbitbrush, and Hood's phlox.

Native species appear to be establishing well at the Large Scale Infiltration Basin. Squirreltail is evident with occasional sagebrush and some of both grey and green rabbitbrush all the way around the rim. There is also some crested wheatgrass and cheatgrass as well as native wheatgrasses and Indian ricegrass. The perimeter and interior has mostly sagebrush, crested wheatgrass, mixed wheatgrasses, bottlebrush squirreltail, foxtail barley (Hordeum jubatum), and both grey and green rabbitbrush with some cheatgrass. Annual and nonnative species within the disturbed area include halogeton, desert alyssum, and cheatgrass.

The 2006 assessment recommended the Large Scale Infiltration Basin continue to be monitored until it reaches the $70 \%$ criteria for final stabilization.

\subsection{Site Assessment}

Vegetation appears to be uniformly distributed throughout the disturbed area. However, a few small bare areas do exist. Transects were located as shown in Figure 13. Table C-7 lists GPS coordinates for plots at this location. Figure B-11 shows a typical background vegetation plot.

Mean perennial cover of the disturbed area at the Large Scale Infiltration Basin site is $62.1 \%$ (Table A-7) of background, and there is a statistically significant difference between mean cover values of the disturbed area compared to background $(\mathrm{p}=0.015)$, and this is likely due to background vegetation containing more shrub cover. Figure B-12 shows vegetation typically encountered in the disturbed area.

\subsection{Actions and Resolutions}

The disturbed area at the Large Scale Infiltration Basin is close to meeting $70 \%$ percent cover of background vegetation. Reaching the final stabilization criteria at the site may be hampered by vehicle traffic associated with RRTR activities. It is recommended that the site continue to be visually evaluated in the yearly revegetation assessment to determine if activities associated with the RRTR are impacting revegetation efforts, and that digital camera sampling be conducted if it appears that RRTR activities are not impeding growth of vegetation and when the area appears to reach the $70 \%$ criteria for final stabilization. 


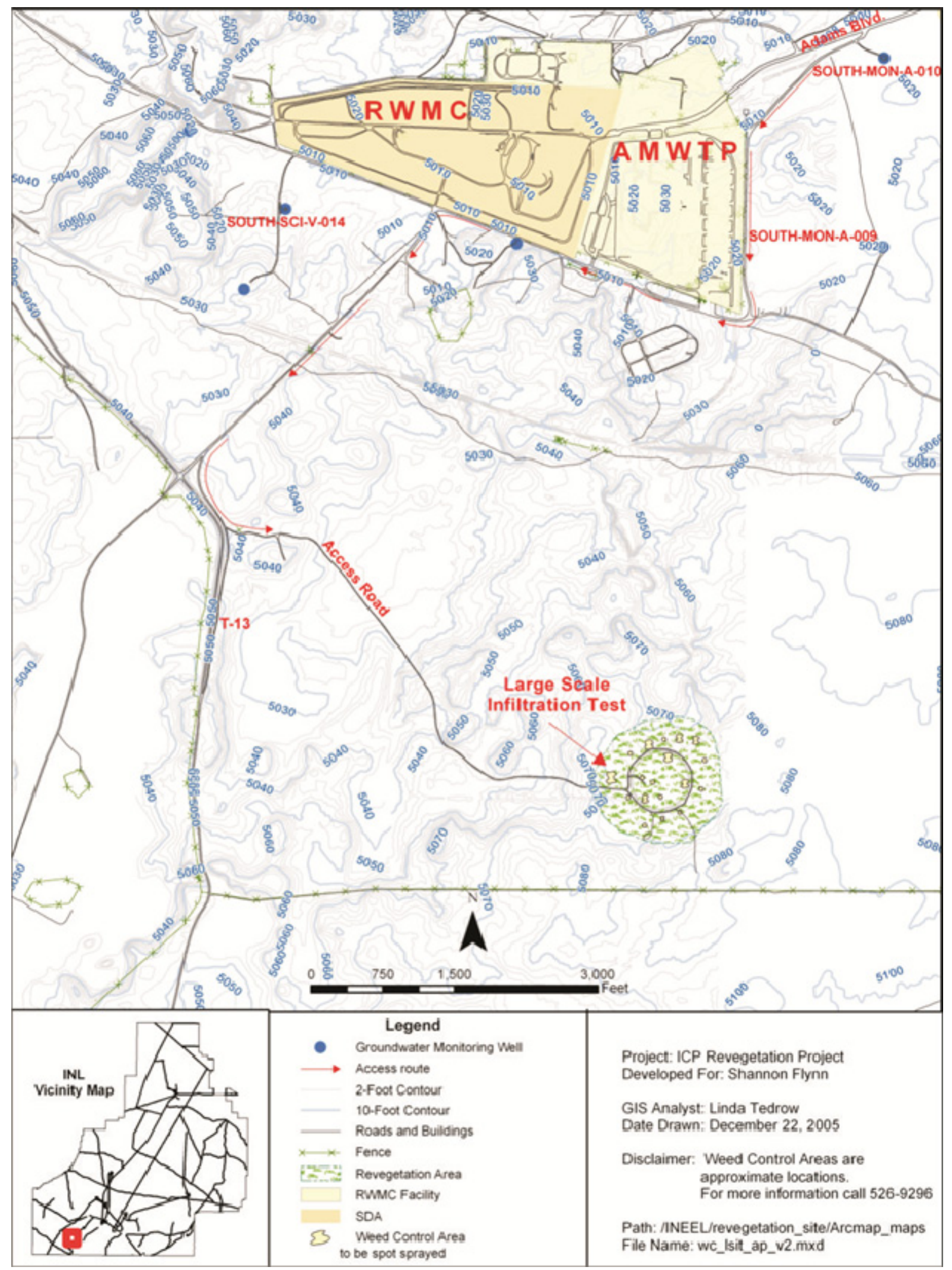

Figure 12. Map of the Large Scale Infiltration Basin. 


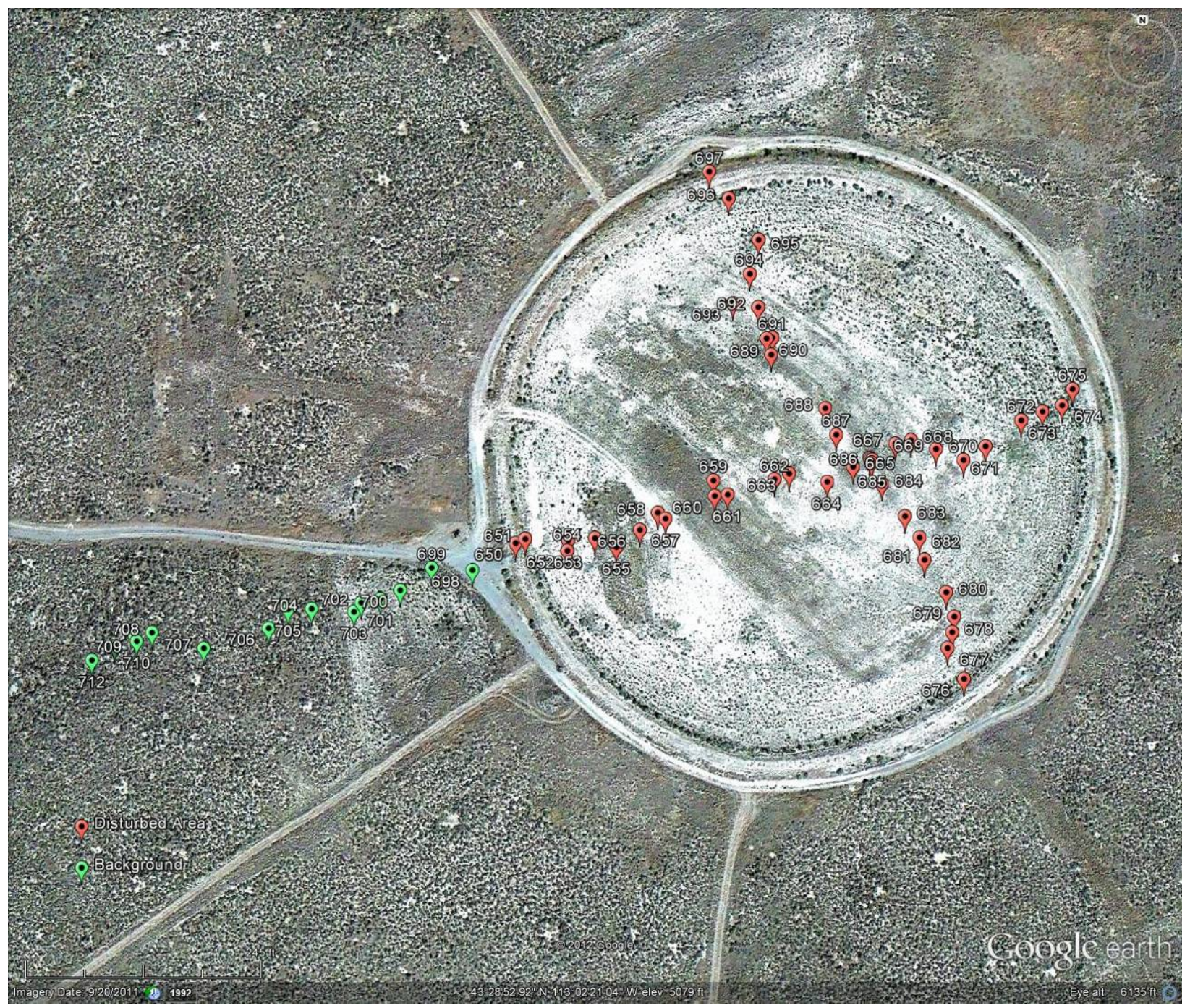

Figure 13. Large Scale Infiltration Basin Transects.

\section{Lincoln Boulevard Borrow Source}

The Lincoln Boulevard Borrow Source is another LTS site located west of Lincoln Boulevard, about 10 miles northeast of CFA and about 1 mile south of Mile Marker 11 on Lincoln Boulevard (Figure 14).

\subsection{Site Background Conditions}

The 2006 assessment noted the following:

"North side - Great grass (i.e., wheatgrasses and Indian ricegrass) establishment; all large bunches with ample seed production. Native annuals (i.e., white-stem blazing star (Mentzelia albicaulis), mustards, western stickseed (Lappula occidentalis) and desert alyssum) were evident. Some large bare areas are also present. Cheatgrass, halogeton, Russian thistle, and kochia are all common with two huge strips of Russian thistle, especially on the north end. On the west edge, 2 wash-outs are present: the first is much larger than last year. The second wash-out is north of the first wash-out. So much soil material is being lost to the old gravel pit from the second wash-out that the hole should be filled. Some native forb growth including globemallow and desert dusty maiden is evident. No shrubs are present. There is still evidence of vehicle traffic but vegetation is growing in the ruts. Pronghorn sign is scattered throughout the site. The perimeter has sagebrush, crested wheatgrass, other wheatgrasses, Indian ricegrass and globemallow." 
Wash-outs and vehicle traffic were not noted in the 2012 assessment of the site. Vehicle traffic in 2012 appeared to be limited to the two-track road that splits the site and provides access to the gravel pit. Crested wheatgrass is the dominant species at the site. Other species noted within the disturbed area include rabbitbrush, Indian rice grass, sagebrush, and wheatgrasses. Cheatgrass, halogeton, and kochia were noted in small amounts, mostly along the road splitting the north and south sides of the disturbed area. Native forbs observed include globemallow and desert dusty maiden. Very few shrubs are present. The area appears to be trending toward a crested wheatgrass monoculture.

\subsection{Site Assessment}

Vegetation appears to be uniformly distributed throughout the disturbed area. Transects were located as show in Figure 14. It was difficult to distinguish boundaries of the disturbed area, so transects did not span the entire disturbed area. Plots were located in areas with the least amount of cover, and actual cover may be higher than what is reported in this assessment. Table C-8 lists GPS coordinates for disturbed area plots at this location. Figure B-13 shows a typical background plot. Because the disturbed site is located in close proximity and in the same type of vegetation, the background transect for the CFA Former Fire Station 2 site was used for background at this location as shown in Figure 7.

Mean perennial cover of the disturbed area at the Lincoln Boulevard Borrow Source site is $86.3 \%$ (Table A-8) of background, and there was no statistically significant difference between mean cover values of the disturbed area and background $(\mathrm{p}=0.203)$. Figure B-14 shows vegetation typically encountered in the disturbed area.

\subsection{Actions and Resolutions}

The disturbed area has achieved final stabilization, and it is recommended that it no longer be monitored and included in future assessments. 


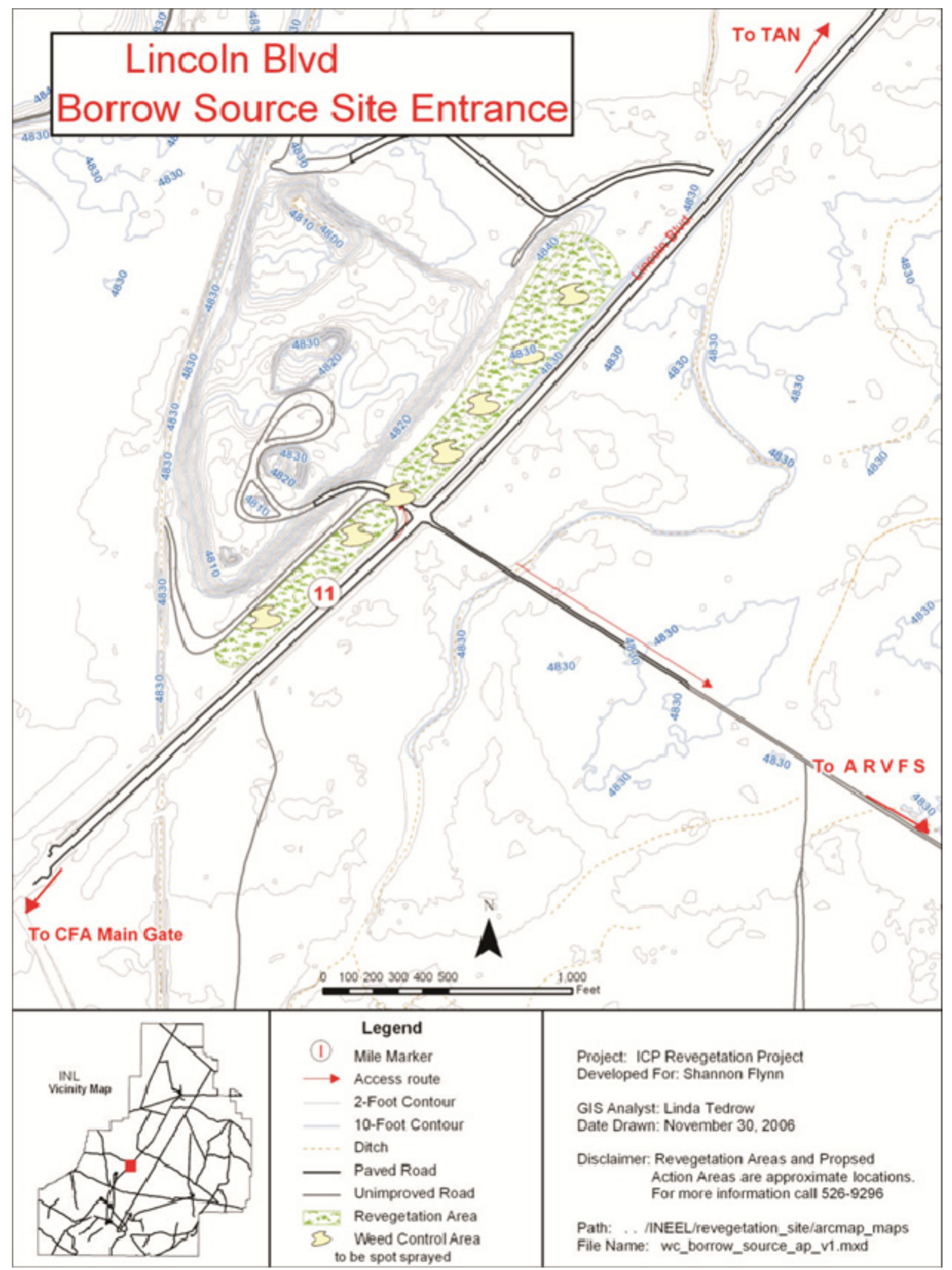

Figure 14. Map of the Lincoln Boulevard Borrow Source. 


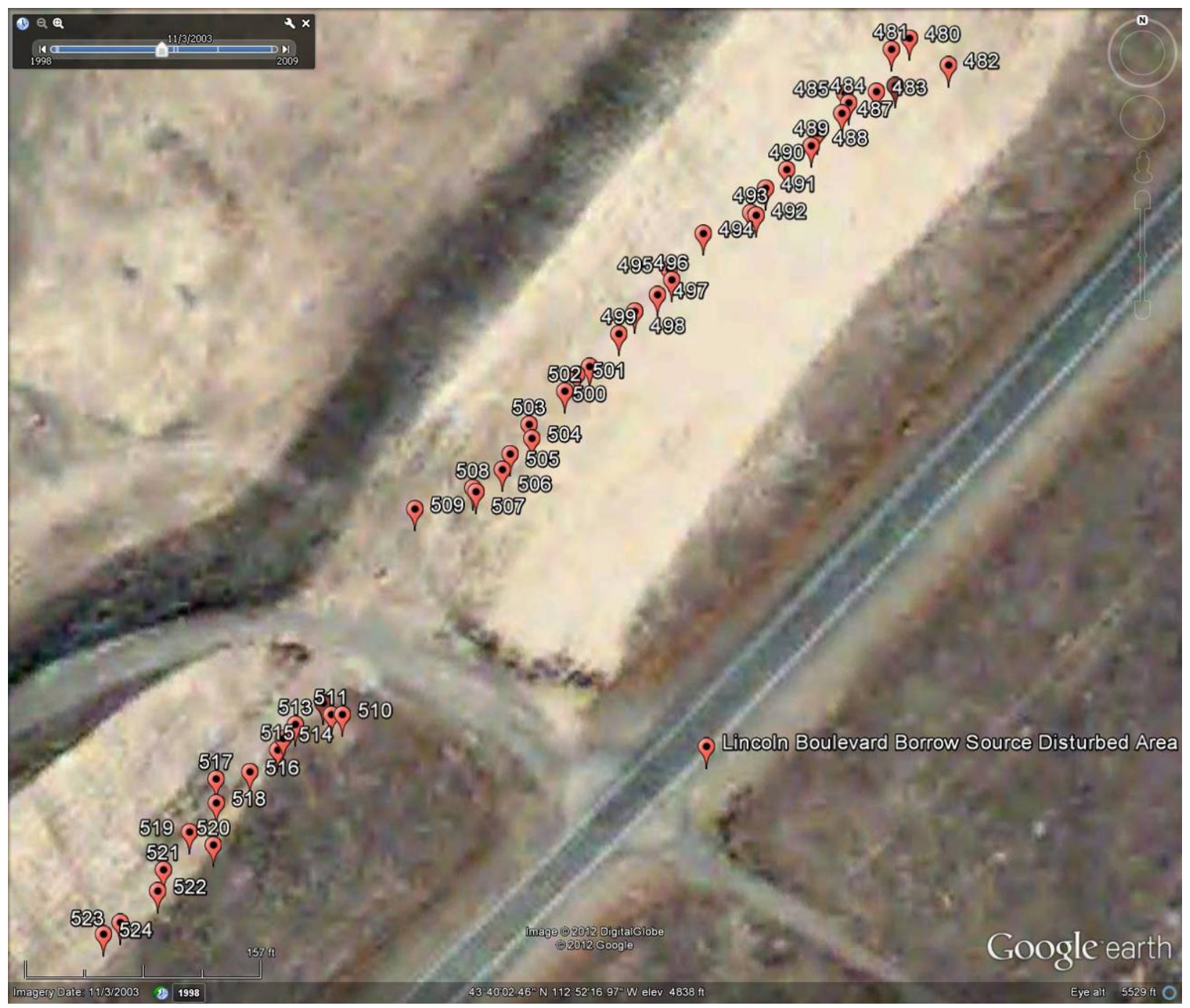

Figure 15. Lincoln Boulevard Borrow Source Transects

\section{Materials and Fuels Complex Industrial Waste Pond}

Contaminated soil was excavated from the MFC Industrial Waste Pond (IWP) and the area was recontoured prior to being reseeded in 2004 with the same native seed mixture used at the Interceptor Canal Mound.

\subsection{Site Background Conditions}

Previous evaluations were performed in 2005 and 2006 (INL 2007). Seven locations within the revegetated area around the IWP were surveyed in 2006. Weedy plant species dominated areas both inside and outside the recontoured/reseeded area. The 2006 evaluation indicated the contaminated topsoil was removed and not replaced. Furthermore, the soil around the MFC IWP was extremely compacted.

\subsection{Site Assessment}

As in 2011, the southern end of the MFC IWP has a good perennial vegetative cover. Species present include Wyoming big sagebrush, green rabbitbrush, crested wheat grass, and globemallow. Several young sagebrush plants were observed. This small area may be close to reaching the $70 \%$ criteria. 
Canada thistle is present in the area surrounding the MFC IWP and ranges from sparse to thick depending on the location. Cheatgrass is present towards the southern end and becomes very thick at the northern end of the MFC IWP. Crested wheatgrass appears to be increasing throughout the area based on the number of young plants observed. This is expected since crested wheatgrass is prevalent in the area surrounding the MFC complex. Kochia was present, especially in the bare areas. Russian knapweed (Rhaponticum repens) is present along the eastern side of the IWP, though it appeared to be less prevalent than in 2011.

\subsection{Actions and Resolutions}

Crested wheatgrass and Wyoming big sagebrush appear to be increasing in certain areas of the revegetation site. A visual evaluation was performed in 2012, and site conditions are similar to what was encountered in 2011.

It is recommended that the site continue to be monitored for weeds and that visual observations continue until the entire site appears to reach final stabilization, at which time the digital camera sampling method will be used to confirm the site has reached $70 \%$ of background cover.

\section{Materials and Fuels Complex Vehicle Barrier Project}

The MFC Vehicle Barrier project included installation of vehicle gate barriers, Delta vehicle crash barriers, and precast concrete vehicle barriers. The precast concrete vehicle barriers were placed around the south and approximately half way up the east side of the MFC facility. An area approximately $10 \mathrm{ft}$ wide was disturbed. The barriers were placed in the middle of the disturbed areas.

Seeding was performed in accordance with Construction Specification SPC-1000, Section 32 9219. Table 2 shows the seed mixture that was specified in SPC-1000; the same seed mixture recommended for MFC Equipment Enclosure and Search Station project. A seed drill was used to plant the seeds, and wood chips were added once the seeding was completed. The work was performed during the week of October 12, 2008.

Table 2. Equipment Vehicle Barrier project seed mixture.

\begin{tabular}{|l|c|}
\hline \multicolumn{1}{|c|}{ Species } & $\begin{array}{c}\text { Rate of Application (pounds per acre pure live } \\
\text { seed) }\end{array}$ \\
\hline Indian Rice Grass "Rimrock" & 2 \\
\hline Thickspiked wheatgrass "Bannock" & 2 \\
\hline Bottlebrush Squirreltail & 2 \\
\hline Green Rabbitbrush & 1 \\
\hline Silverleaf Lupine & 1 \\
\hline
\end{tabular}

\subsection{Site Background Conditions}

The MFC Vehicle Barrier Project is located within an area consisting almost entirely of crested wheatgrass, with thickspiked wheatgrass present in very small amounts. It is expected that the disturbed areas of the MFC Vehicle Barrier Project will eventually revert back to a crested wheatgrass monoculture.

\subsection{Site Assessment}

A visual vegetation assessment was performed in 2012. Based on the visual observation, a determination was made not to use the digital camera sampling and analysis method.

As in previous years, crested wheatgrass is the most prevalent grass in both the background and the disturbed areas. Cheat grass is present in most areas and abundant in some. Bottlebrush squirreltail was more common along the barrier on the east side of MFC. It was abundant in some locations and sparse in 
others. In 2012, areas on the road side of the concrete barriers and within the barriers near the NOAA tower had been mowed.

The east barrier may be nearing the $70 \%$ criteria. On the east side of the east barrier, there is considerably more cheatgrass and kochia. Bottlebrush squirreltail was relatively abundant along the east barrier. Canada thistle was observed within the disturbed area of the east barrier site.

The northeast portion of the barrier is expected to meet the $70 \%$ criteria (Figure 6). This area is dominated by crested wheatgrass with bottlebrush squirreltail and a few Wyoming big sagebrush plants intermixed.

Cheatgrass appears to be the most dominant grass species along the south barrier (Figure 7). Kochia, tanseymustard, and Canada thistle were also present in this area. This portion of the barrier project is not expected to meet the $70 \%$ criteria at this time.

The west side barrier appears to meet the $70 \%$ criteria. Vegetation along this portion of the barrier consists primarily of crested wheatgrass. A few small bare areas exist.

A soil pile was located on the south side of the road that runs east and west along the southern barriers. In late October 2010, the soil pile was removed to grade. In the 2010 Annual Revegetation Assessment, it was suggested that the area be revegetated using an appropriate seed mix, and hydroseeding of the area was performed in 2012.

\subsection{Actions and Resolutions}

Because the area surrounding the project is dominated by crested wheatgrass, it is expected that crested wheatgrass will eventually become the dominant species on the disturbed sites. Visual evaluations should continue to be performed and weeds monitored. On subsequent visits to the site, it was noted that thistle had been sprayed, and this should continue as long as infestations are observed.

Mowing of areas will likely continue as part of INL fuel management in accordance with the environmental assessment for Wildland Fire Management (DOE/EA-1732). For these areas, vegetation should be considered complete until mowing no longer occurs.

A visual evaluation should be performed again in 2013 to determine whether digital camera sampling and analysis should be performed on the area within the barriers. Crested wheatgrass will be used to determine final stabilization.

The reseeded soil pile should be monitored for weeds and weed control performed as necessary. Visual observations of the area will continue until revegetation establishment approaches $70 \%$, at which time digital camera sampling will be performed to verify final stabilization.

\section{National Security Test Range Project}

On September 9, 2008, a survey of sites disturbed by the NSTR project along the T-25 road was performed by NSTR personnel and the S. M. Stoller Corporation (Saupe 2009). The survey identified seven locations that required seeding (Table 3 ).

Table 4 shows the seed mix recommended by the S. M. Stoller Corporation for reseeding the seven disturbed sites. Disturbed sites were seeded late fall 2008.

Table 3. Table showing T-25 road sites where seeding was recommended.

\begin{tabular}{|l|l|}
\hline \multicolumn{1}{|c|}{ Location } & \multicolumn{1}{c|}{ Comments } \\
\hline Wide spot north of power pole 138 & $\begin{array}{l}\text { A large mud rick has been bladed at an angle } \\
\text { and should be revegetated. }\end{array}$ \\
\hline Across from power pole 146 & $\begin{array}{l}\text { There is an area that appears to have been } \\
\text { backed into during construction. This area }\end{array}$ \\
\hline
\end{tabular}




\begin{tabular}{|l|l|}
\hline & needs to be seeded. \\
\hline North of power pole 170 & Disturbed during construction, reseed. \\
\hline Power pole 176 & $\begin{array}{l}\text { Truck turn around area. Revegetate on the west } \\
\text { side of the pole. }\end{array}$ \\
\hline Power pole 179 & Disturbed during construction, reseed. \\
\hline North of power pole 181 & Disturbed during construction, reseed. \\
\hline Turn-off on east end of range access road & Reseed south half. \\
\hline
\end{tabular}

Table 4. Recommended seed mixture for T-25 road disturbed sites.

\begin{tabular}{|l|c|}
\hline \multicolumn{1}{|c|}{ Species } & $\begin{array}{c}\text { Rate of Application (pounds per acre pure live } \\
\text { seed) }\end{array}$ \\
\hline Indian Rice Grass "Rimrock" & 2 \\
\hline Thickspiked wheatgrass "Bannock" & 2 \\
\hline Bottlebrush Squirreltail & 2 \\
\hline Green Rabbitbrush & 1 \\
\hline
\end{tabular}

\subsection{Site Background Conditions}

The NSTR Project is located within a sagebrush steppe community. Wyoming big sagebrush is dominant on undisturbed sites in this area, although other species of big sagebrush are co-dominant. Needle and Thread grass and Indian ricegrass are the dominant grasses. Other plant species observed throughout the background include: tapertip hawksbeard, cushion buckwheat, shaggy fleabane, green rabbitbrush, and Hood's phlox.

All sites along the T-25 road associated with the NSTR project achieved final stabilization prior to the 2012 revegetation assessment except the area near power pole 179. In 2011, mean perennial cover at the location was $33.9 \%$ of background.

\subsection{Site Assessment}

\subsubsection{North of Power pole 179}

A visual assessment of the site was conducted in 2012. Tumble mustard and skeleton weed were not as prevalent as in 2011. However, heavy gravel at the southern end of the disturbed area is still impeding regrowth of the vegetation and the area appears to be receiving some vehicle traffic. Native grasses in the disturbed area include needle and thread grass, Indian rice grass, and thickspiked wheat grass. Green rabbitbrush is also re-establishing. Site conditions appear similar to 2011.

\subsection{Actions and Resolutions}

It is recommended that the disturbed area north of power pole 179 continue to be monitored for progress towards meeting the $70 \%$ criteria for final stabilization.

\section{Vadose Zone Research Park}

The Vadose Zone Research Park (VZRP) is a field-scale research facility designed to investigate the behavior of water and solute movement through the vadose zone. The site is located northwest of Central Facilities Area along the Big Lost River and adjacent to the new Idaho Nuclear Technology and Engineering Center (INTEC) Percolation Ponds. An important feature of this research facility is that it established a natural baseline for subsurface conditions prior to the inception of the new INTEC Percolation Ponds. The site consists of several two-track roads, numerous well locations, and a vehicle crossing across the Big Lost River (Figure 12). 


\subsection{Site Background Conditions}

The VZRP is located within a large area previously burned by wildfire. Background vegetation was assumed to be represented by the reestablished burn area. Perennial vegetation observed within the background transects included sagebrush, rabbitbrush, shaggy fleabane, lupine, Indian rice grass, needle and thread grass, bottlebrush squirreltail, crested wheatgrass, and thickspiked wheatgrass. Western tansymustard, and Jim Hill tumblemustard were annual species present. Cheat grass is prevalent throughout the background. Hoary aster is prevalent along roadsides, disturbed areas, and limited in background areas.

\subsection{Site Assessment}

Previous assessments of the VZRP determined that all disturbed locations had met final stabilization requirements except wells 201A, 202A, 203, 204, and 209.

The 2011 annual report stated that wells 202A, 203, and 204 would be visually evaluated to determine if digital camera is warranted. A visual observation was performed, and it was obvious that these well sites would not meet the $70 \%$ of background criteria. The heavy cheatgrass infestation is making it impossible for establishment of native perennial vegetation. Jim Hill tumblemustard was also present at this location. A few native grasses were observed. These included bottlebrush squirreltail and Sandberg bluegrass. In addition, rabbitbrush and shaggy fleabane were also noted.

Digital camera sampling was conducted on wells 201A and 209. Cover of background vegetation was measured by combining all background transects from the 2011 assessment as shown in Figure 17. Figure B-15 shows a vegetation plot typical of the background area.

\subsubsection{Well 201A}

This well is located on the southeast side of the new INTEC Percolation Ponds. Vegetation in the disturbed area includes shaggy fleabane, phlox, bottlebrush squirrel tail, green rabbitbrush, and cushion buckwheat. Cheat grass, desert alyssum, and Jim Hill tumblemustard are also present. Transects were located as shown in Figure 18. Plot coordinates are listed in tables C-9. Figure B-16 shows a typical disturbed area plot for well 201A.

Native perennial vegetation in the disturbed area around well 201A is $78.5 \%$ of background (Table A9), and there is not a statistically significant difference between the background and disturbed vegetation $(\mathrm{p}=0.0 .075)$. The site has achieved final stabilization.

\subsubsection{Well 209}

The well is located on the southwest side of the new INTEC Percolation Ponds. The south, east, and west sides of the disturbed site are primarily covered with cheatgrass and Jim hill tumblemustard. The north side has quite a few Sandberg bluegrass plants mixed with a few bottlebrush squirreltail and green rabbitbrush plants. The surrounding area contains significant amounts of cheatgrass. Transects were located as shown in Figure 19. Plot coordinates are listed in tables C-9. Figure B-17 shows a typical disturbed area plot for well 201A.

Native perennial vegetation in the disturbed area around well 209 is $49.8 \%$ of background (Table A10 ), and there is a statistically significant difference between mean cover for the background and disturbed vegetation $(\mathrm{p}=0.001)$. The site has not achieved final stabilization. 


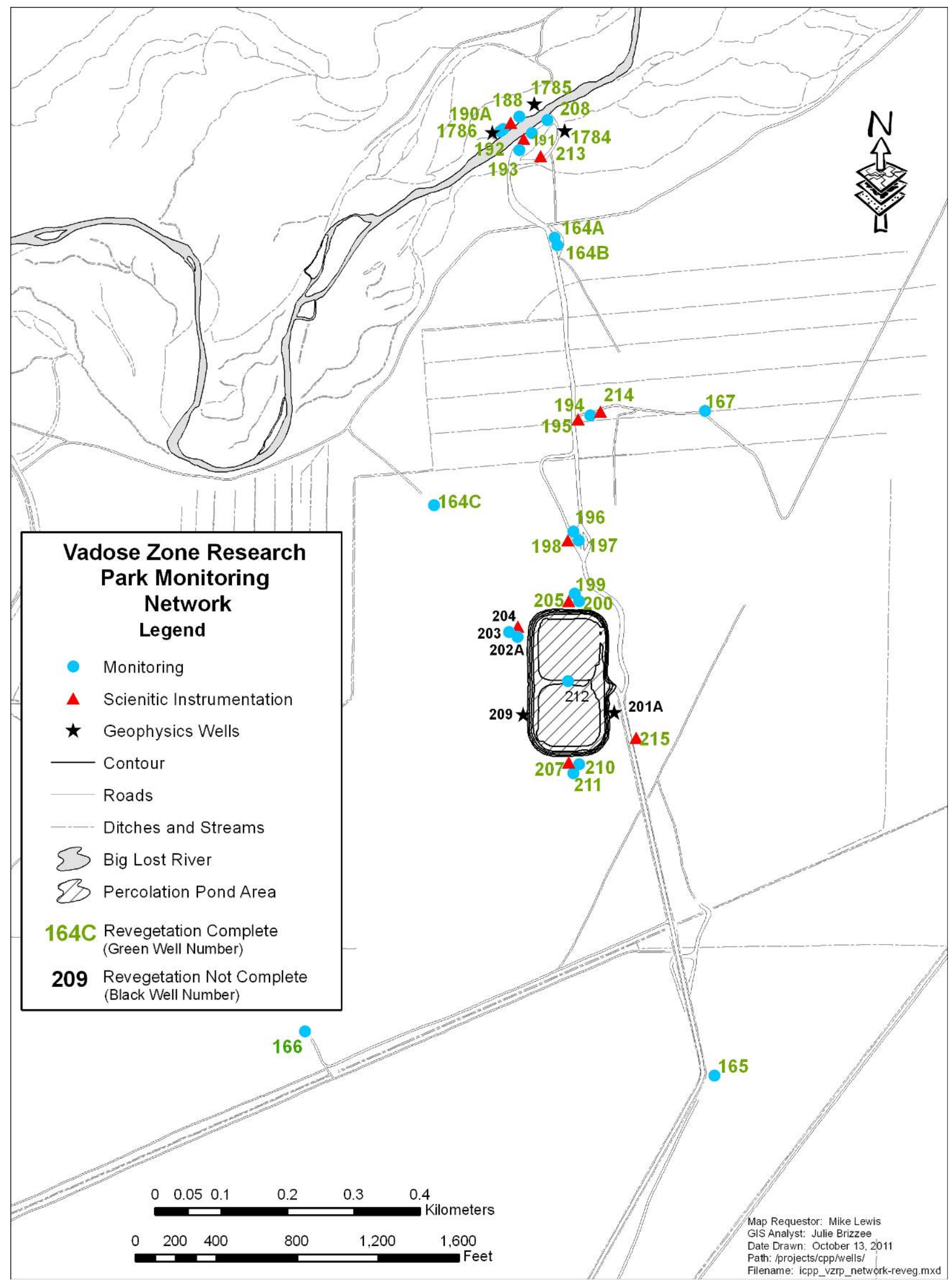

Figure 16. Map of the Vadose Zone Research Park. 


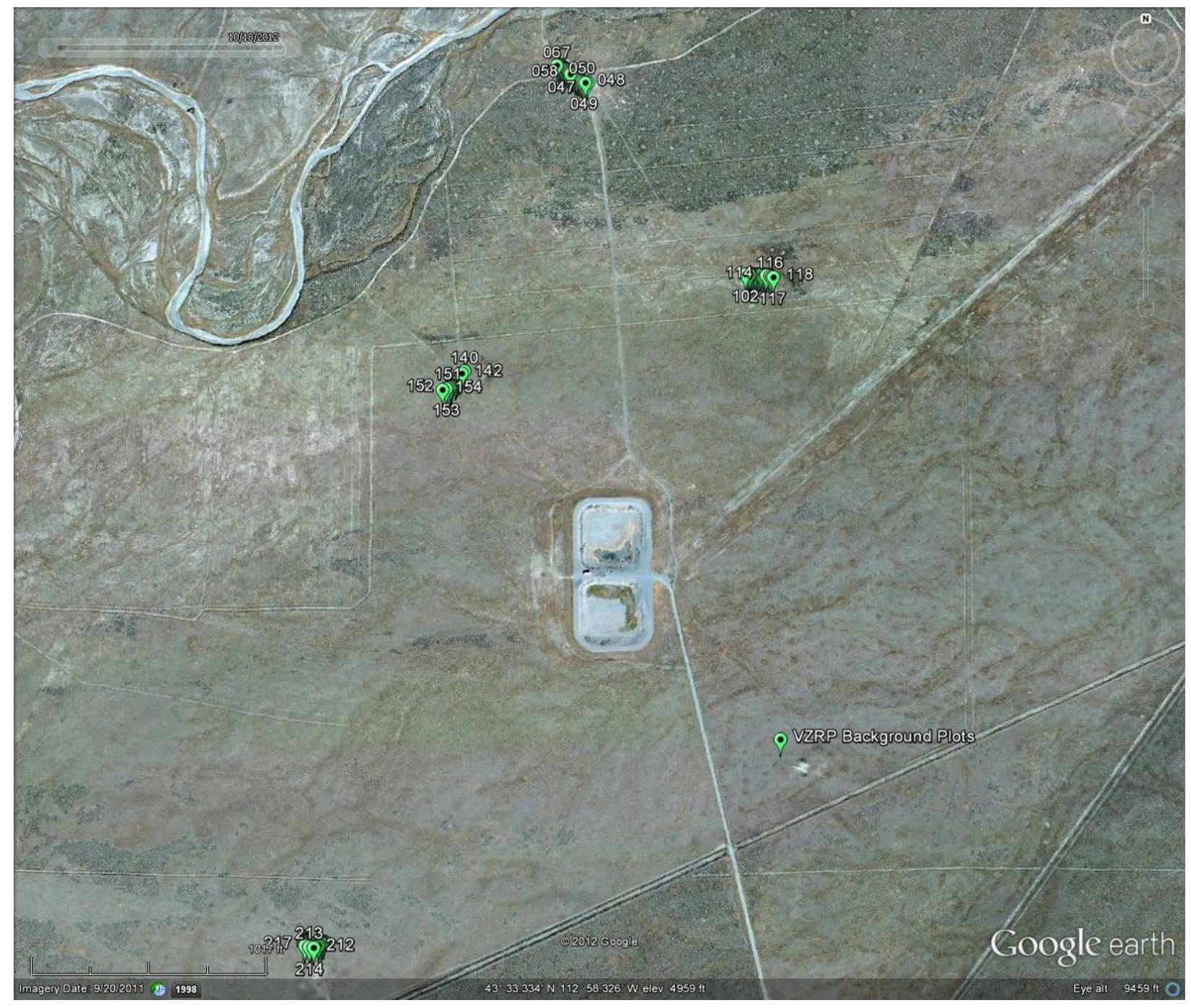

Figure 17. VZRP Background Transect Locations.

\subsection{Actions and Resolutions}

The disturbed areas surrounding well 201A has achieved final stabilization.

Wells 202A, 203, 204, and 209 still exhibit a high concentration of annual species such as tansymustard and cheatgrass. These wells are all located adjacent to the berm of the new INTEC Percolation Ponds. It does not appear that weed control has been conducted on the graveled berm. Cheatgrass on the berm provides a constant seed source to the disturbed areas of the wells adjacent to it. Even if intensive restoration of the disturbed areas around those wells were to take place, it is likely that cheatgrass would continue to invade.

As with the trenches for the GI Project, disturbed sites at the VZRP were revegetated to the requirements for "final stabilization" found in Appendix A (definition section) of the 2003 CGP. This definition and the requirements are discussed in section 7.3 of this report. 


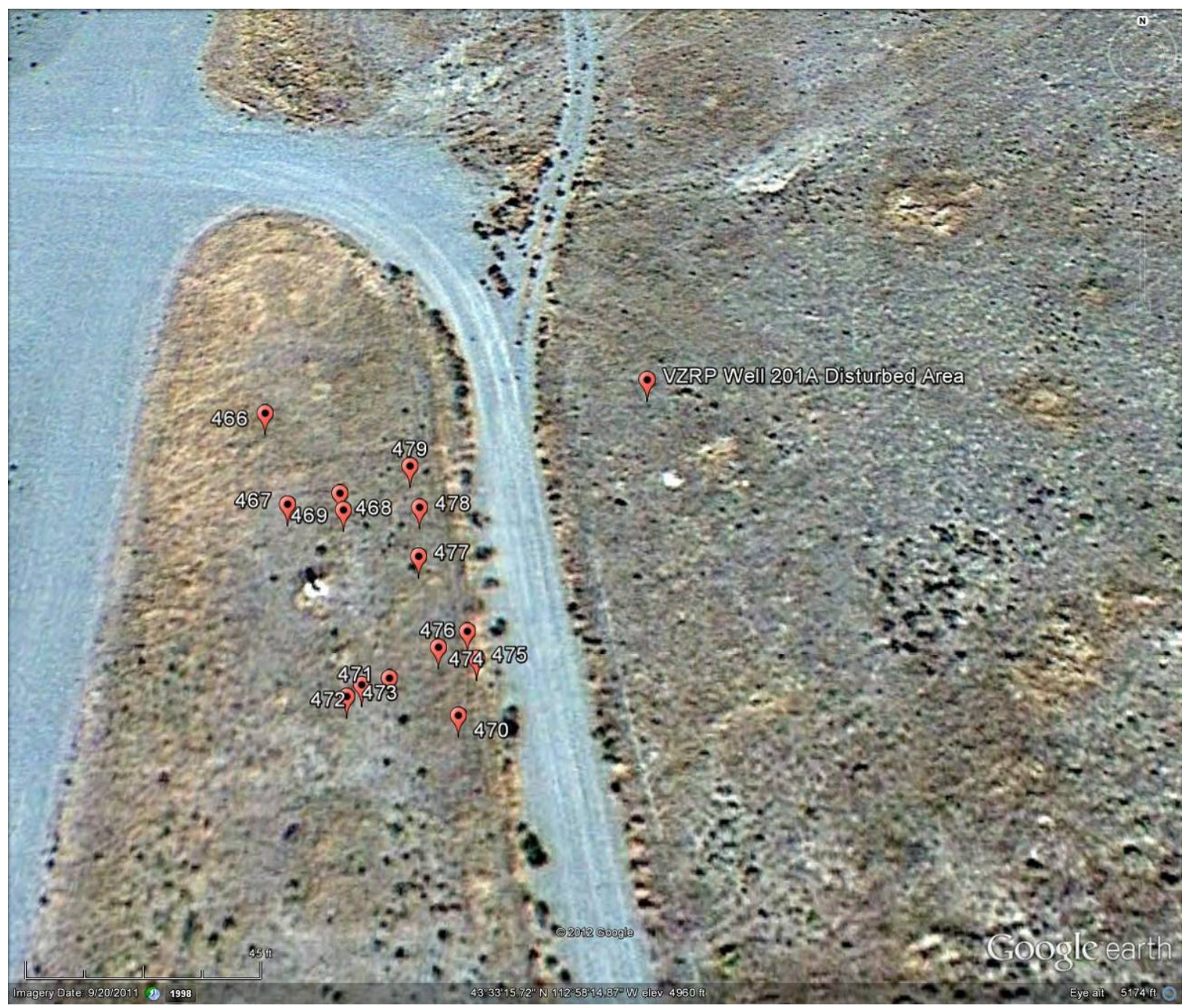

Figure 18. VZRP Well 201A Disturbed Area Transect Locations. 


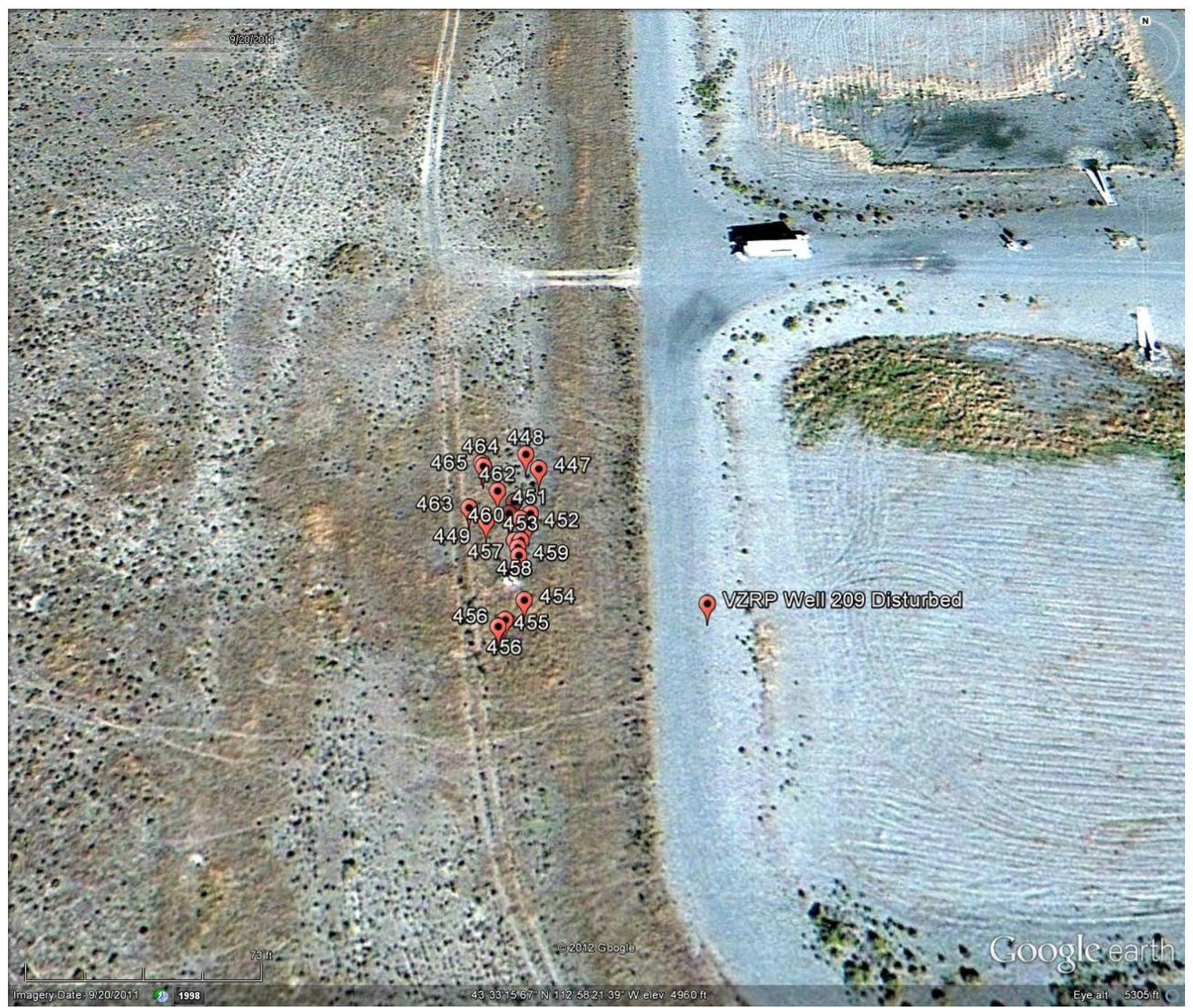

Figure 19. VZRP Well 209 Disturbed Area Transect Locations.

The criteria was satisfied at the VZRP since the perennial seed mix and erosion controls were selected, designed and installed to provide erosion control for at least 3 years without active maintenance, and the temporary erosion control measures were selected, designed, and installed to achieve $70 \%$ vegetative coverage within 3 years.

However, while the disturbed locations at the VZRP have met the CGP requirements, they have not achieved the $70 \%$ cover of native perennial background final stabilization criteria used across the INL. Because succession in areas invaded by cheatgrass is slow, and at this time it is not practical or economical to disturb soil and revegetate the area again, it is recommended that the disturbed areas of the VZRP be visually evaluated every three to five years until they appear to be reaching the criteria for final stabilization. BEA should continue to explore and evaluate technologies and relevant scientific information regarding the eradication of cheatgrass that may assist these areas in achieving $70 \%$ cover of native perennial background vegetation. 


\section{References}

Allen, Edith B.; Jackson, Laura L. 1992. The arid West. Restoration \& Management Notes. 10(1): 56-59.

Anderson, Jay E.; Marlette, Guy M. 1986. Probabilities of seedling recruitment and the stability of crested wheatgrass stands. In: Johnson, Kendall L., ed. Crested wheatgrass: its values, problems and myths: Symposium proceedings; 1983 Oct. 3-7; Logan, UT. Logan, UT: Utah State University: 97-105.

Anderson, J.E. and M.L. Shumar. 1989 Guidelines for revegetation of disturbed sites on the Idaho National Engineering Laboratory. DOE/ID-12114. Idaho National Engineering Laboratory, U.S. Department of Energy Idaho Field Office, Idaho Falls, ID.

Bethlenfalvay, Gabor J.; Dakessian, Suren. 1984. Grazing effects on mycorrhizal colonization and floristic composition of the vegetation on a semiarid range in northern Nevada. Journal of Range Management. 37(4): 312-316. [439]

Brandt, C. A.; Rickard, W. H. 1994. Alien taxa in the North American shrub-steppe four decades after cessation of livestock grazing and cultivation agriculture. Biological Conservation. 68(2): 95-105.

Brochu, R. A., U.S. Army Corps of Engineers, to J. A. Stenzel, INL, May 26, 2009, NWW-20033200690-101, CCN 217716.

Chatterton, N. Jerry. 1994. Fructan metabolism and cool-temperature growth in cheatgrass. In: Monsen, Stephen B.; Kitchen, Stanley G., compilers. Proceedings--ecology and management of annual rangelands; 1992 May 18-22; Boise, ID. Gen. Tech. Rep. INT-GTR-313. Ogden, UT: U.S. Department of Agriculture, Forest Service, Intermountain Research Station: 333-336.

Cline, J. F.; Rickard, W. H. 1973. Herbage yields in relation to soil water and assimilated nitrogen. Journal of Range Management. 26(4): 296-298.

Daubenmire, R. 1970. Steppe vegetation of Washington. Technical Bulletin 62. Pullman, WA: Washington State University, College of Agriculture; Washington Agricultural Experiment Station. 131 p.

DOE-ID. 2003. Idaho National Engineering and Environmental Laboratory Wildland Fire Management Environmental Assessment. DOE/EA-1372.

Doerr, Phillip D.; Keith, Lloyd B.; Rusch, Donald H. 1971. Effects of fire on a ruffed grouse population. In: Proceedings, annual Tall Timbers fire ecology conference; 1970 August 20-21; Fredericton, NB. No. 10. Tallahassee, FL: Tall Timbers Research Station: 25-46.

Eddleman, Lee E.; Doescher, Paul S. 1978. Selection of native plants for spoils revegetation based on regeneration characteristics and successional status. In: Land Reclamation Program, Annual Report July 1976-October 1977. ANL/LRP-2. Argonne, IL: Argonne National Laboratory, Energy \& Environmental Systems Division: 132-138.

Floyd, Donald A. and J.E. Anderson. 1987. A comparison of three methods for estimating plant cover. The Journal of Ecology, Vol. 75, No. 1, Mar. 1987. 221-228.

Forman, Amy D., Hafla, Jackie R., Stoller Corporation, S. M., February 2010. Big Lost River Trenches Revegetation Demonstration Project Progress Report and Formal Revegetation Assessment 2009. StollerESER-125. 
Franklin, Jerry F.; Dyrness, C. T. 1973. Natural vegetation of Oregon and Washington. Gen. Tech. Rep. PNW-8. Portland, OR: U.S. Department of Agriculture, Forest Service, Pacific Northwest Forest and Range Experiment Station. 417 p.

Goodrich, Sherel; Gale, Natalie. 1999. Cheatgrass frequency at two relic sites within the pinyon-juniper belt of Red Canyon. In: Monsen, Stephen B.; Stevens, Richard, compilers. Proceedings: ecology and management of pinyon-juniper communities within the Interior West: Sustaining and restoring a diverse ecosystem; 1997 September 15-18; Provo, UT. Proceedings RMRS-P-9. Ogden, UT: U.S. Department of Agriculture, Forest Service, Rocky Mountain Research Station: 69-71.

Hardy BBT Limited. 1989. Manual of plant species suitability for reclamation in Alberta. 2d ed. Report No. RRTAC 89-4. Edmonton, AB: Alberta Land Conservation and Reclamation Council. 436 p.

Harris, Grant A. 1967. Some competitive relationships between Agropyron spicatum and Bromus tectorum. Ecological Monographs. 37(2): 89-111.

Harris, Grant A.; Goebel, Carl J. 1976. Factors of plant competition in seeding Pacific Northwest bunchgrass ranges. Bulletin 820. Pullman, WA: Washington State University, College of Agriculture Research Center. 27 p.

Hurley, C. A.; Wicklow-Howard, M. 1986. The occurrence of vesicular-arbuscular mycorrhizae associated with Artemisia tridentata var. wyomingenesis within burned areas of the Idaho. Journal of the Idaho Academy of Science. 22(1): 7. Abstract.

Hironaka, Minoru. 1961. The relative rate of root development of cheatgrass and medusahead. Journal of Range Management. 14: 263-267.

Hironaka, M.; Tisdale, E. W. 1963. Secondary succession in annual vegetation in southern Idaho. Ecology. 44(4): 810-812.

Hulbert, Lloyd C. 1955. Ecological studies of Bromus tectorum and other annual bromegrasses. Ecological Monographs. 25(2): 181-213.

Idaho Department of Environmental Quality. 2005. Catalog of Stormwater Best Management Practices for Idaho Cities and Counties. September 2005.

ICP, 2007. Weed Control and Revegetation Status Report for Fiscal Year 2006. RPT-305. January 2007.

INL, 2007, 2006 Evaluation of Revegetation Success at the Industrial Waste Pond (ANL-01) and Interceptor Canal-Mound (ANL-09) CERCLA Sites, INL/EXT-06-11837, Idaho National Laboratory, March 2007.

Jensen, M. E.; Peck, L. S.; Wilson, M. V. 1988. A sagebrush community type classification for mountainous northeastern Nevada rangelands. The Great Basin Naturalist. 48: 422-433.

Laycock, W. A. 1991. Stable states and thresholds of range condition on North American rangelands: a viewpoint. Journal of Range Management. 44(5): 427-433.

McIver, James; Starr, Lynn. 2001. Restoration of degraded lands in the interior Columbia River basin: passive vs. active approaches. Forest Ecology and Management. 153: 15-28.

Melgoza, Graciela; Nowak, Robert S. 1991. Competition between cheatgrass and two native species after fire: implications from observations and measurements of root distribution. Journal of Range Management. 44(1): 27-33. 
Melgoza, Graciela; Nowak, Robert S.; Tausch, Robin J. 1990. Soil water exploitation after fire: competition between Bromus tectorum (cheatgrass) and two native species. Oecologia. 83(1): 7-13.

Minnesota Pollution Control Agency. 2008. Stormwater Compliance Assistance Toolkit for Small Construction Operators. August 2008.

Monsen, Stephen B. 1994. The competitive influences of cheatgrass (Bromus tectorum) on site restoration. In: Monsen, Stephen B.; Kitchen, Stanley G., compilers. Proceedings--ecology and management of annual rangelands; 1992 May 18-22; Boise, ID. Gen. Tech. Rep. INT-GTR-313. Ogden, UT: U.S. Department of Agriculture, Forest Service, Intermountain Research Station: 43-50.

Mosely, Jeffrey C.; Bunting, Stephen C.; Manoukian, Mark E. 1999. Cheatgrass. In: Sheley, Roger L.; Petroff, Janet K., eds. Biology and management of noxious rangeland weeds. Corvallis, OR: Oregon State University Press: 175-188.

Saupe, D. S., to M. G. Lewis, email, July 6, 2009, Corrections to Survey Information.

Schafer, Annette. 2009. Establishing Revegetation Performance Measures at the INL.

Sheehy, Dennis P.; Winward, A. H. 1981. Relative palatability of seven Artemisia taxa to mule deer and sheep. Journal of Range Management. 34(5): 397-399.

Shive, J. P., et al., 2011, Vegetation Community Classification and Mapping of the INL, January 2011, GSS-ESER-144.

Stahl, Peter D.; Williams, S. E.; Christensen, Martha. 1988. Efficacy of native vesicular-arbuscular mycorrhizal fungi after severe soil disturbance. New Phytologist. 110(3): 347-354.

Stenzel, J., to R. Brochu, U.S. Army Corps of Engineers, May 7, 2008. Request for Jurisdictional Determinations for Big Lost River, Little Lost River, and Birch Creek at the Idaho National Laboratory. CCN 213583.

Vallentine, John F.; Stevens, Allan R. 1994. Use of livestock to control cheatgrass--a review. In: Monsen, Stephen B.; Kitchen, Stanley G., compilers. Proceedings--ecology and management of annual rangelands; 1992 May 18-22; Boise, ID. Gen. Tech. Rep. INT-GTR-313. Ogden, UT: U.S. Department of Agriculture, Forest Service, Intermountain Research Station: 202-206.

Walker, Lawrence R.; Smith, Stanley D. 1997. Impacts of invasive plants on community and ecosystem properties. In: Luken, James O.; Thieret, John W., eds. Assessment and management of plant invasions. New York: Springer-Verlag: 69-86.

Wambolt, C.L., et. al. 2001. Recovery of big sagebrush communities after burning in southwestern Montana. Journal of Environmental Management. 61:243-252.

Wambolt, Carl L.; Watts, Myles J. 1996. High stocking rate potential for controlling Wyoming big sagebrush. In: Barrow, Jerry R. et. al. Proceedings: shrubland ecosystems dynamics in a changing environment. 1995 May 23-25; Las Cruces. NM. General Technical Report. INT-GTR-338. Ogden, UT: U.S. Department of Agriculture, Forest Service, Intermountain Research Station:148-150.

Welch, Bruce L.; Criddle, Craig. 2003. Countering Misinformation Concerning Big Sagebrush. United States Department of Agriculture Forest Service. Rocky Mountain Research Station. Research Paper RMRS-RP-40. July 2003. 
Wicklow-Howard, Marcia. 1989. The occurrence of vesicular-arbuscular mycorrhizae in burned areas of the Snake River Birds of Prey Area, Idaho. Mycotaxon. 34(1): 253-257.

Young, James A. 1991. Cheatgrass. In: James, Lynn F.; Evans, John O., eds. Noxious range weeds. Westview Special Studies in Agriculture Science and Policy. Boulder, CO: Westview Press, Inc: 408-418.

Young, James A.; Allen, Fay L. 1997. Cheatgrass and range science: 1930-1950. Journal of Range Management. 50(5): 530-535.

Young, James A.; Evans, Raymond A.; Eckert, Richard E., Jr.; Kay, Burgess L. 1987. Cheatgrass. Rangelands. 9(6): 266-270.

Young, James A.; Evans, Raymond A. 1973. Downy brome--intruder in the plant succession of big sagebrush communities in the Great Basin. Journal of Range Management. 26(6): 410-415. 


\section{Appendix A Assessment Summary Tables}


Table A-1. Comparison of BORAX-V revegetation to background vegetation.

\begin{tabular}{|l|l|l|l|}
\hline Category & \% in Background & \% in Disturbed Area & Disturbed Percentage of Background \\
\hline Cover\% (STD) & $34.4(20.4)$ & $36.3(16.2)$ & 105.5 \\
\hline Grass\% (STD) & $12.6(15.3)$ & $21.0(15.8)$ & 166.7 \\
\hline Forb\% (STD) & $0.00(0.00)$ & $0.35(1.00)$ & NA \\
\hline Shrub\% (STD) & $21.8(18.8)$ & $10.9(18.8)$ & 50.0 \\
\hline Cactus\%(STD) & $0.00(0.00)$ & $0.00(0.00)$ & NA \\
\hline Litter\% (STD) & $24.5(11.0)$ & $24.3(8.45)$ & 99.2 \\
\hline Soil\% (STD) & $38.3(17.4)$ & $28.8(13.4)$ & 75.2 \\
\hline Rock\% (STD) & $2.2(3.30)$ & $9.7(11.1)$ & 440.9 \\
\hline Unknown\% (STD) & $0.67(0.82)$ & $0.71(0.81)$ & 106.0 \\
\hline Annual\% (STD) & $0.00(0.00)$ & $0.29(1.24)$ & NA \\
\hline $\begin{array}{l}\text { \# of Quadrates Used for Background: } 12 \\
\text { \# of Total Sample Points Used for Background: 768 }\end{array}$ \\
\# of Quadrates Used for Disturbed Area: 27 \\
\# of Total Sample Points Used for Disturbed Area: 1728 \\
\hline
\end{tabular}

Table A-2. Comparison of CFA-04 Pond Remediation revegetation to background vegetation.

\begin{tabular}{|c|c|c|c|}
\hline Category & $\%$ in Background & $\%$ in Disturbed Area & Disturbed Percentage of Background \\
\hline Cover\% (STD) & $26.2(17.5)$ & 23.1(16.95) & 88.2 \\
\hline Grass\% (STD) & $2.51(6.07)$ & $19.1(12.4)$ & 761.0 \\
\hline Forb\% (STD) & $0.00(0.00)$ & $0.35(1.00)$ & NA \\
\hline Shrub\% (STD) & $23.7(19.1)$ & $3.61(16.00)$ & 152.3 \\
\hline Cactus\%(STD) & $0.00(0.00)$ & $0.04(0.27)$ & NA \\
\hline Litter\% (STD) & $24.5(11.6)$ & 46. 1(21.3) & 188.2 \\
\hline Soil\% (STD) & $48.1(15.1)$ & $22.8(19.7)$ & 47.4 \\
\hline Rock\% (STD) & $0.413(0.85)$ & $3.26(3.02)$ & 789.3 \\
\hline Unknown\% (STD) & $0.9(0.932)$ & $0.84(0.81)$ & 93.3 \\
\hline Annual\% (STD) & $0.00(0.00)$ & 4.82(13.14) & NA \\
\hline \multicolumn{4}{|c|}{$\begin{array}{l}\text { \# of Quadrates Used for Background: } 23 \\
\text { \# of Total Sample Points Used for Background: } 1472 \\
\text { \# of Quadrates Used for Disturbed Area: } 36 \\
\text { \# of Total Sample Points Used for Disturbed Area: } 2304\end{array}$} \\
\hline
\end{tabular}


Table A-3. Comparison of CFA Former Fire Station II revegetation to background vegetation.

\begin{tabular}{|c|c|c|c|}
\hline Category & $\%$ in Background & $\%$ in Disturbed Area & Disturbed Percentage of Background \\
\hline Cover\% (STD) & $41.6(12.04)$ & $33.3(27.56)$ & 80.0 \\
\hline Grass\% (STD) & $37.8(16.53)$ & $33.1(27.26)$ & 87.6 \\
\hline Forb\% (STD) & $0.00(0.00)$ & $0.00(0.00)$ & NA \\
\hline Shrub\% (STD) & $3.78(9.92)$ & $0.26(0.89)$ & 6.89 \\
\hline Cactus\%(STD) & $0.00(0.00)$ & $0.00(0.00)$ & NA \\
\hline Litter\% (STD) & $39.0(8.52)$ & $53.3(30.63)$ & 136.7 \\
\hline Soil\% (STD) & $15.7(11.37)$ & $5.3(5.13)$ & 33.8 \\
\hline Rock\% (STD) & $2.88(4.66)$ & $6.4(14.49)$ & 222.2 \\
\hline Unknown\% (STD) & $0.84(0.82)$ & $1.71(1.03)$ & 203.6 \\
\hline Annual\% (STD) & $0.00(0.00)$ & $0.00(0.00)$ & NA \\
\hline \multicolumn{4}{|c|}{$\begin{array}{l}\text { \# of Quadrates Used for Background: } 19 \\
\text { \# of Total Sample Points Used for Background: } 1216 \\
\text { \# of Quadrates Used for Disturbed Area: } 12 \\
\text { \# of Total Sample Points Used for Disturbed Area: } 768\end{array}$} \\
\hline
\end{tabular}

Table A-4. Comparison of revegetation of Geomorphic Investigations for Flood Bounds North Saddle Trench to background vegetation.

\begin{tabular}{|c|c|c|c|}
\hline Category & $\%$ in Background & $\%$ in Disturbed Area & Disturbed Percentage of Background \\
\hline Cover\% (STD) & $34.8(16.5)$ & $14.1(10.88)$ & 40.5 \\
\hline Grass \% (STD) & $22.0(11.82)$ & $11.2(10.02)$ & 50.9 \\
\hline Forb\% (STD) & $0.27(0.62)$ & $0.67(1.23)$ & 248.1 \\
\hline Shrub\% (STD) & $12.5(19.35)$ & $2.23(5.90)$ & 178.4 \\
\hline Cactus\%(STD) & $0.00(0.00)$ & $0.00(0.00)$ & NA \\
\hline Litter\% (STD) & 43.1(13.77) & $52.7(23.3)$ & 122.2 \\
\hline Soil\% (STD) & $18.2(12.03)$ & $19.2(19.71)$ & 105.5 \\
\hline Rock\% (STD) & $0.00(0.00)$ & $4.49(7.14)$ & NA \\
\hline Unknown\% (STD) & $2.09(1.67)$ & $1.36(2.31)$ & 65.1 \\
\hline Annual\% (STD) & $1.83(2.28)$ & $8.26(12.35)$ & 451.4 \\
\hline \multicolumn{4}{|c|}{$\begin{array}{l}\text { \# of Quadrates Used for Background: } 12 \\
\text { \# of Total Sample Points Used for Background: } 768 \\
\text { \# of Quadrates Used for Disturbed Area: } 7 \\
\text { \# of Total Sample Points Used for Disturbed Area: } 448\end{array}$} \\
\hline
\end{tabular}


Table A-5. Comparison of revegetation of Geomorphic Investigations for Flood Bounds South Saddle Trench to background vegetation.

\begin{tabular}{|c|c|c|c|}
\hline Category & $\%$ in Background & $\%$ in Disturbed Area & Disturbed Percentage of Background \\
\hline Cover\% (STD) & $34.8(16.5)$ & $18.9(9.85)$ & 54.3 \\
\hline Grass \% (STD) & $22.0(11.82)$ & $17.7(11.08)$ & 80.5 \\
\hline Forb\% (STD) & $0.27(0.62)$ & $0.87(1.77)$ & 322.2 \\
\hline Shrub\% (STD) & $12.5(19.35)$ & $0.34(1.03)$ & 2.72 \\
\hline Cactus\%(STD) & $0.00(0.00)$ & $0.00(0.00)$ & NA \\
\hline Litter\% (STD) & 43.1(13.77) & $59.7(13.70)$ & 138.5 \\
\hline Soil\% (STD) & $18.2(12.03)$ & $3.14(4.57)$ & 172.5 \\
\hline Rock\% (STD) & $0.00(0.00)$ & $0.52(1.57)$ & NA \\
\hline Unknown\% (STD) & $2.09(1.67)$ & $0.53(0 . .8)$ & 253.6 \\
\hline Annual\% (STD) & $1.83(2.28)$ & $17.2(10.04)$ & 939.9 \\
\hline \multicolumn{4}{|c|}{$\begin{array}{l}\text { \# of Quadrates Used for Background: } 12 \\
\text { \# of Total Sample Points Used for Background: } 768 \\
\text { \# of Quadrates Used for Disturbed Area: } 9 \\
\text { \# of Total Sample Points Used for Disturbed Area: } 576\end{array}$} \\
\hline
\end{tabular}

Table A-6. Comparison of revegetation of Geomorphic Investigations for Flood Bounds Southwest Big Loop Trench to background vegetation.

\begin{tabular}{|l|l|l|l|}
\hline Category & \% in Background & $\%$ in Disturbed Area & Disturbed Percentage of Background \\
\hline Cover\% (STD) & $34.8(16.5)$ & $4.57(3.37)$ & 13.1 \\
\hline Grass\% (STD) & $22.0(11.82)$ & $2.71(3.07)$ & 12.3 \\
\hline Forb\% (STD) & $0.27(0.62)$ & $0.72(1.26)$ & 266.7 \\
\hline Shrub\% (STD) & $12.5(19.35)$ & $1.14(2.78)$ & 9.1 \\
\hline Cactus\%(STD) & $0.00(0.00)$ & $0.00(0.00)$ & NA \\
\hline Litter\% (STD) & $43.1(13.77)$ & $68.3(9.90)$ & 158.5 \\
\hline Soil\% (STD) & $18.2(12.03)$ & $2.99(4.09)$ & 16.4 \\
\hline Rock\% (STD) & $0.00(0.00)$ & $1.71(2.81)$ & NA \\
\hline Unknown\% (STD) & $2.09(1.67)$ & $1.00(1.23)$ & 47.8 \\
\hline Annual\% (STD) & $1.83(2.28)$ & $21.5(9.38)$ & 1174.9 \\
\hline $\begin{array}{l}\text { \# of Quadrates Used for Background: } 12 \\
\text { \# of Total Sample Points Used for Background: } 768\end{array}$ \\
\# of Quadrates Used for Disturbed Area: 22 \\
\# of Total Sample Points Used for Disturbed Area: 1408 \\
\hline
\end{tabular}


Table A-7. Comparison of revegetation of Large Scale Infiltration Basin to background vegetation.

\begin{tabular}{|c|c|c|c|}
\hline Category & $\%$ in Background & $\%$ in Disturbed Area & Disturbed Percentage of Background \\
\hline Cover\% (STD) & $36.9(19.88)$ & $22.9(16.20)$ & 62.1 \\
\hline Grass \% (STD) & $10.9(11.03)$ & $20.1(13.63)$ & 184.4 \\
\hline Forb\% (STD) & $0.00(0.00)$ & $0.03(0.23)$ & NA \\
\hline Shrub\% (STD) & $25.9(23.15)$ & $2.77(11.89)$ & 106.9 \\
\hline Cactus\%(STD) & $0.00(0.00)$ & $0.00(0.00)$ & NA \\
\hline Litter\% (STD) & $26.1(12.09)$ & $17.8(8.73)$ & 68.2 \\
\hline Soil\% (STD) & $31.4(16.87)$ & $56.7(18.58)$ & 180.6 \\
\hline Rock\% (STD) & $4.27(3.80)$ & $1.70(2.56)$ & 39.8 \\
\hline Unknown\% (STD) & $1.37(1.43)$ & $0.87(0.81)$ & 63.5 \\
\hline Annual\% (STD) & $0.00(0.00)$ & $0.07(0.32)$ & NA \\
\hline \multicolumn{4}{|c|}{$\begin{array}{l}\text { \# of Quadrates Used for Background: } 15 \\
\text { \# of Total Sample Points Used for Background: } 960 \\
\text { \# of Quadrates Used for Disturbed Area: } 49 \\
\text { \# of Total Sample Points Used for Disturbed Area: } 3136\end{array}$} \\
\hline
\end{tabular}

Table A-8. Comparison of revegetation of Lincoln Blvd Borrow Source to background vegetation.

\begin{tabular}{|c|c|c|c|}
\hline Category & $\%$ in Background & $\%$ in Disturbed Area & Disturbed Percentage of Background \\
\hline Cover\% (STD) & $41.6(12.04)$ & $35.88(17.80)$ & 86.3 \\
\hline Grass\% (STD) & $37.8(16.53)$ & $34.6(18.08)$ & 91.5 \\
\hline Forb\% (STD) & $0.00(0.00)$ & $0.68(2.20)$ & NA \\
\hline Shrub\% (STD) & $3.78(9.92)$ & $0.55(2.47)$ & 14.6 \\
\hline Cactus\%(STD) & $0.00(0.00)$ & $0.03(0.24)$ & NA \\
\hline Litter\% (STD) & $39.0(8.52)$ & $33.9(11.96)$ & 86.9 \\
\hline Soil\% (STD) & $15.7(11.37)$ & $25.5(14.84)$ & 162.4 \\
\hline Rock\% (STD) & $2.88(4.66)$ & $1.98(3.37)$ & 68.8 \\
\hline Unknown\% (STD) & $0.84(0.82)$ & $0.80(0.87)$ & 95.2 \\
\hline Annual\% (STD) & $0.00(0.00)$ & $2.04(6.05)$ & NA \\
\hline \multicolumn{4}{|c|}{$\begin{array}{l}\text { \# of Quadrates Used for Background: } 19 \\
\text { \# of Total Sample Points Used for Background:1216 } \\
\text { \# of Quadrates Used for Disturbed Area: } 36 \\
\text { \# of Total Sample Points Used for Disturbed Area:2304 }\end{array}$} \\
\hline
\end{tabular}


Table A-9. Comparison of VZRP well 201A to background vegetation

\begin{tabular}{|c|c|c|c|}
\hline Category & $\%$ in Background & $\%$ in Disturbed Area & Disturbed Percentage of Background \\
\hline Cover\% (STD) & $21.9(12.51)$ & $17.2(12.65)$ & 78.5 \\
\hline Grass \% (STD) & $14.0(11.85)$ & $13.3(7.76)$ & 95.0 \\
\hline Forb\% (STD) & $4.0(4.84)$ & $0.57(0.80)$ & 14.3 \\
\hline Shrub\% (STD) & $3.88(10.84)$ & $3.35(12.53)$ & 86.3 \\
\hline Cactus\%(STD) & $0.00(0.00)$ & $0.00(0.00)$ & $\mathrm{NA}$ \\
\hline Litter\% (STD) & $37.1(12.56)$ & $54.5(11.68)$ & 146.9 \\
\hline Soil\% (STD) & $17.2(8.95)$ & $7.04(4.66)$ & 40.9 \\
\hline Rock\% (STD) & $12.0(11.45)$ & $6.82(5.18)$ & 56.8 \\
\hline Unknown\% (STD) & $1.43(1.24)$ & $1.47(0.96)$ & 102.8 \\
\hline Annual\% (STD) & $10.4(15.32)$ & $13.1(8.93)$ & 123.0 \\
\hline \multicolumn{4}{|c|}{$\begin{array}{l}\text { \# of Quadrates Used for Background: } 83 \\
\text { \# of Total Sample Points Used for Background: } 5312 \\
\text { \# of Quadrates Used for Disturbed Area: } 14 \\
\text { \# of Total Sample Points Used for Disturbed Area:896 }\end{array}$} \\
\hline
\end{tabular}

Table A-10. Comparison of VZRP well 209 to background.

\begin{tabular}{|l|l|l|l|}
\hline Category & $\%$ in Background & $\%$ in Disturbed Area & Disturbed Percentage of Background \\
\hline Cover\% (STD) & $21.9(12.51)$ & $10.9(14.94)$ & 49.8 \\
\hline Grass\% (STD) & $14.0(11.85)$ & $9.29(14.82)$ & 66.4 \\
\hline Forb\% (STD) & $4.0(4.84)$ & $0.25(0.50)$ & 6.25 \\
\hline Shrub\% (STD) & $3.88(10.84)$ & $0.74(2.56)$ & 19.1 \\
\hline Cactus\%(STD) & $0.00(0.00)$ & $0.57(2.50)$ & NA \\
\hline Litter\% (STD) & $37.1(12.56)$ & $54.0(18.88)$ & 145.6 \\
\hline Soil\% (STD) & $17.2(8.95)$ & $5.85(9.27)$ & 34.0 \\
\hline Rock\% (STD) & $12.0(11.45)$ & $4.60(8.77)$ & 38.3 \\
\hline Unknown\% (STD) & $1.43(1.24)$ & $1.42(0.24)$ & 99.3 \\
\hline Annual\% (STD) & $10.4(15.32)$ & $23.3(16.37)$ & 224.0 \\
\hline \# of Quadrates Used for Background: 83 \\
\# of Total Sample Points Used for Background: 5312 \\
\# of Quadrates Used for Disturbed Area: 19 \\
\# of Total Sample Points Used for Disturbed Area: 1216 \\
\hline
\end{tabular}


Appendix B

FY 2011 Revegetation Photographs 


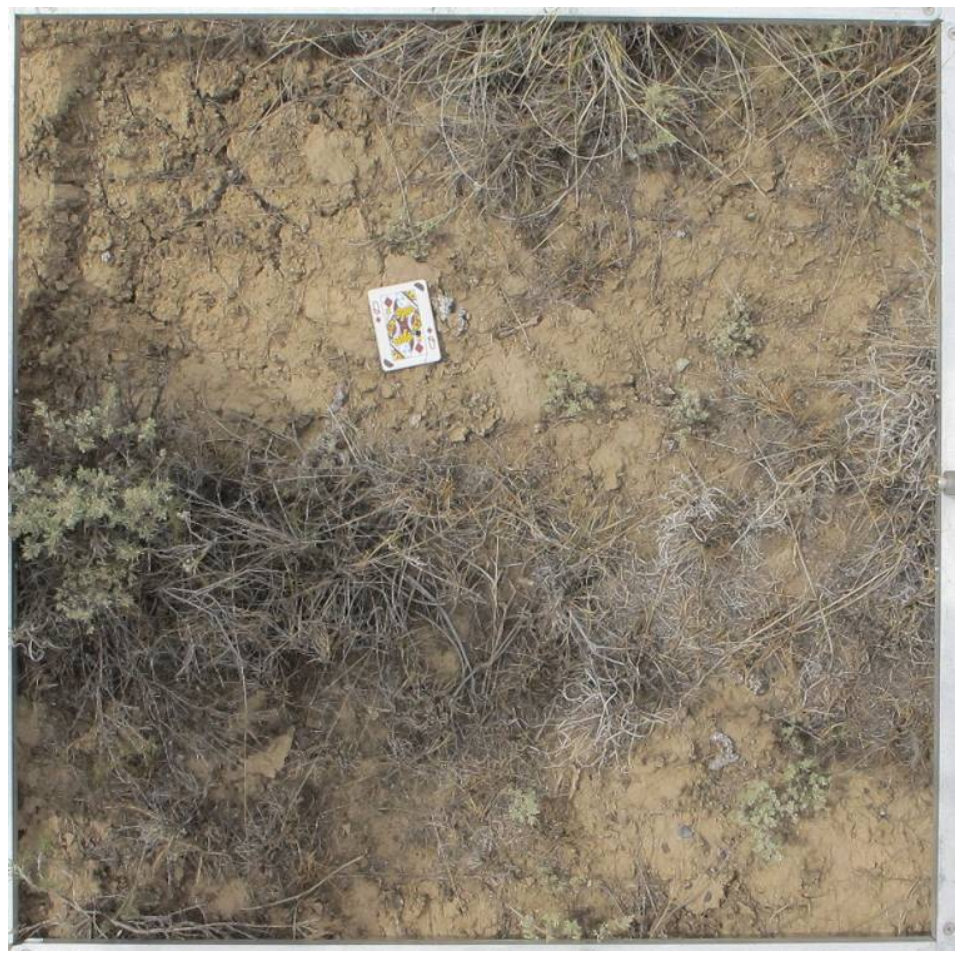

Figure B-1. Background vegetation plot at BORAX-V.

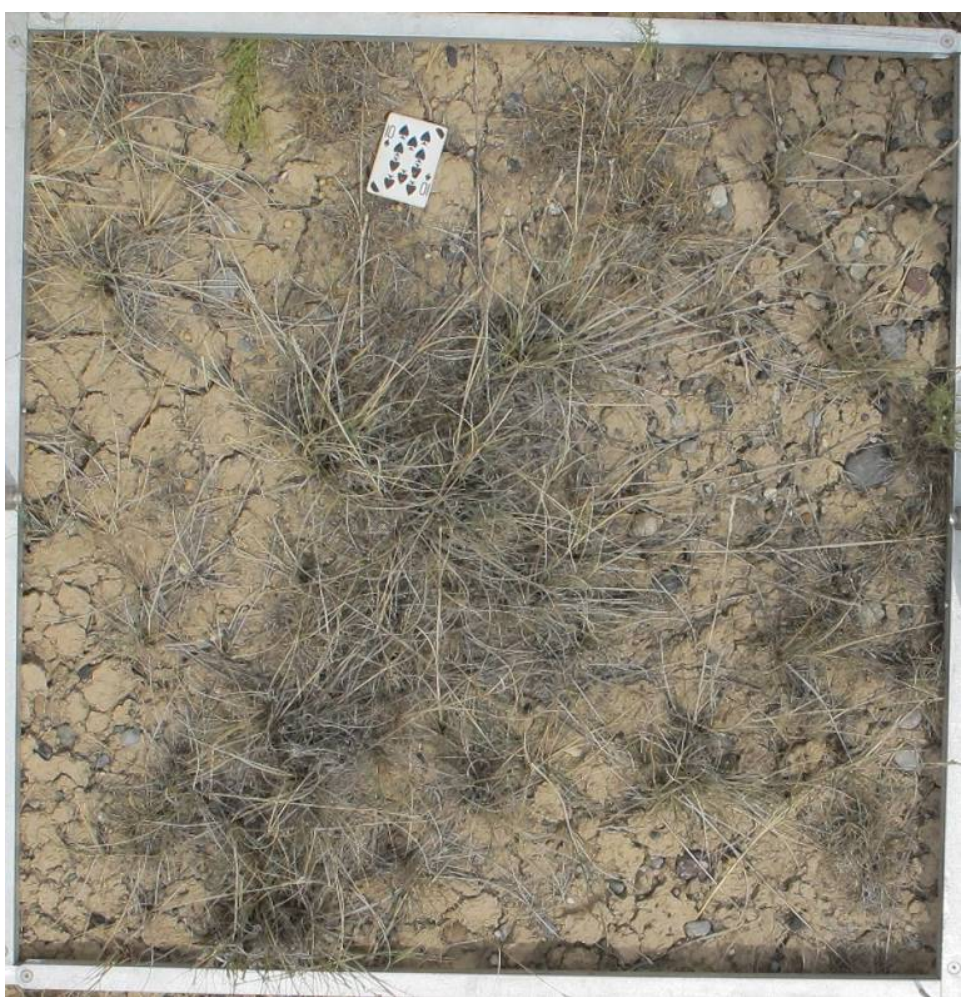

Figure B-2. Disturbed vegetation plot at BORAX-V. 


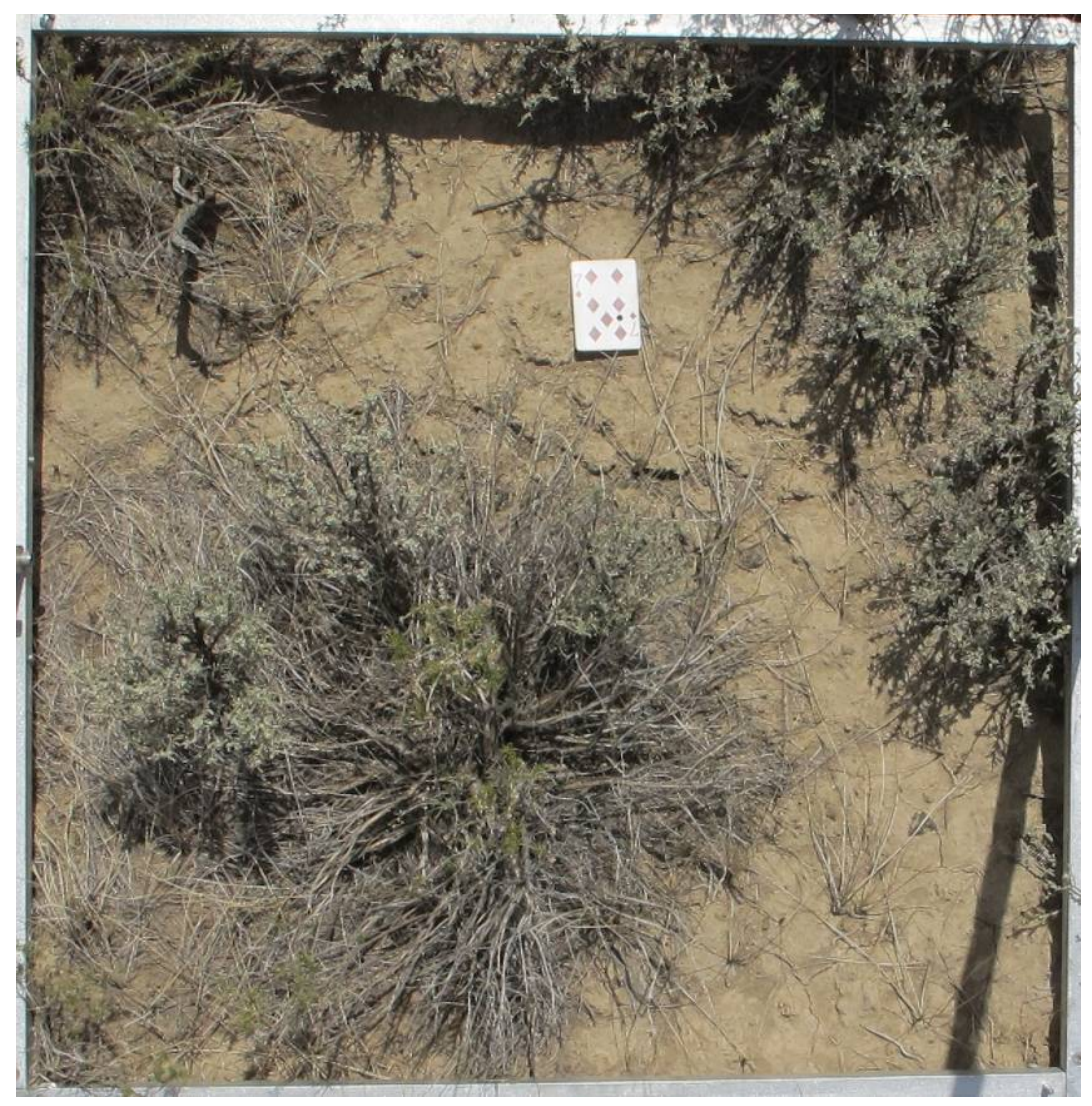

Figure B-3. Background Vegetation Plot at CFA-4 Pond Remediation Site.

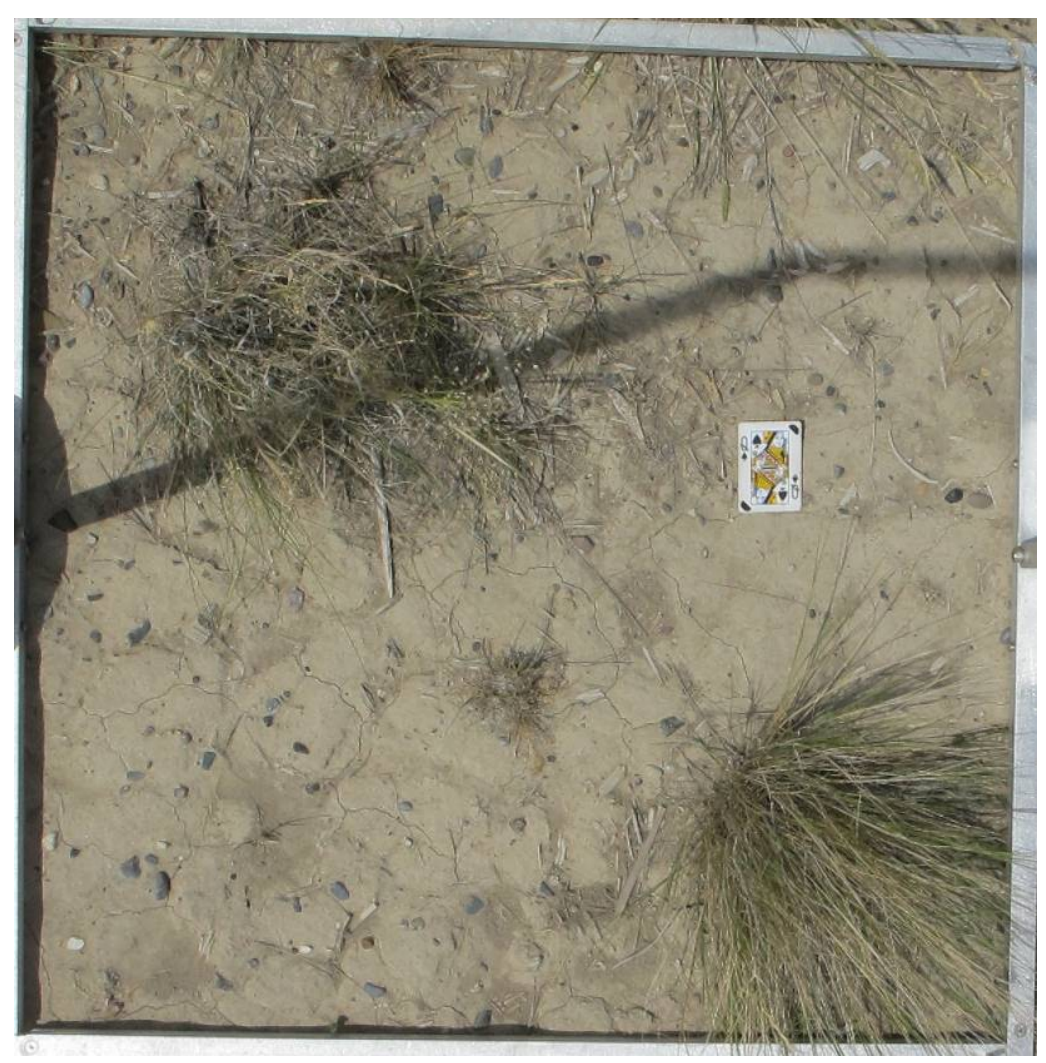

Figure B-4. Disturbed Vegetation Plot at CFA-04 Pond Remediation Site. 


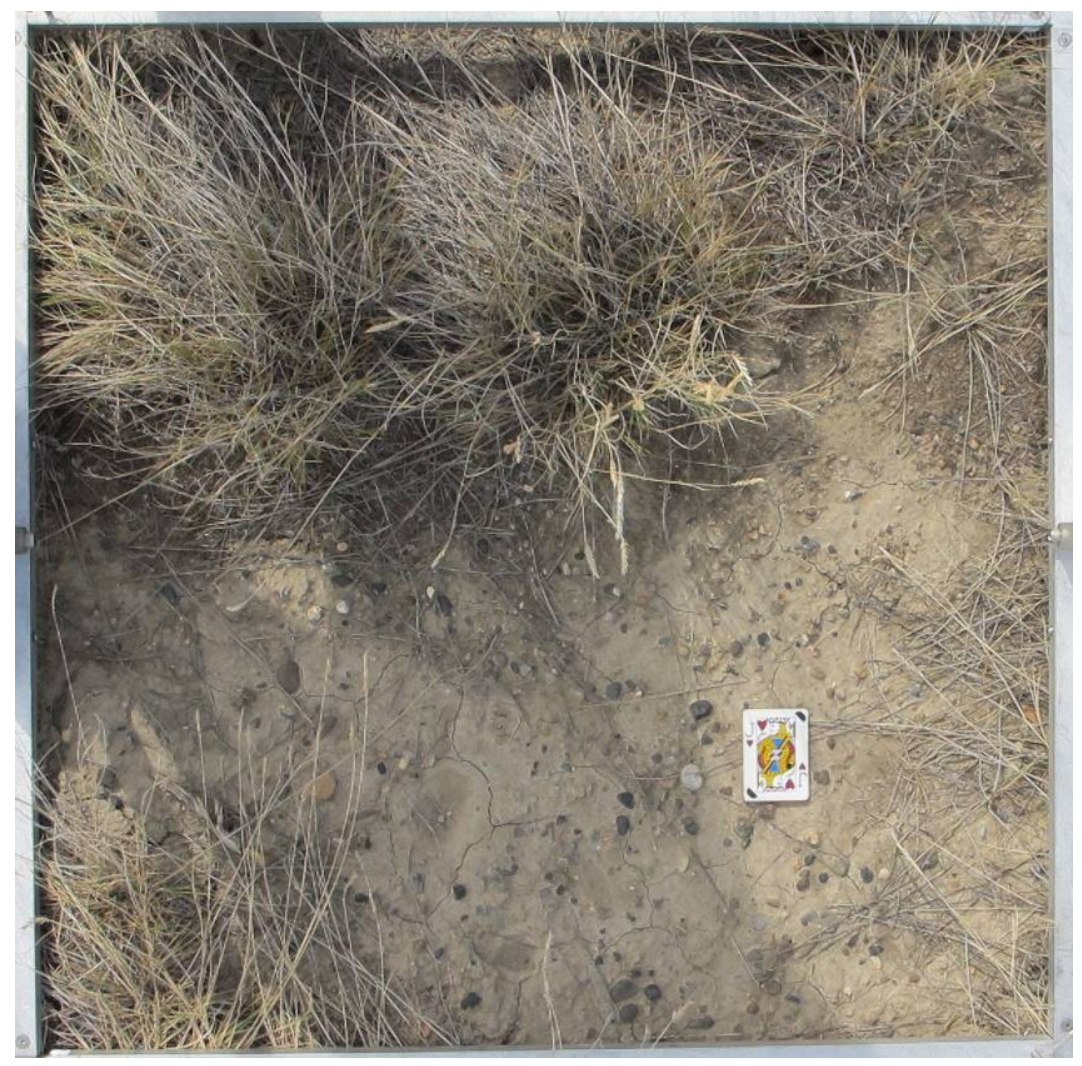

Figure B-5. Background Vegetation Plot at the CFA Former Fire Station 2 Site.

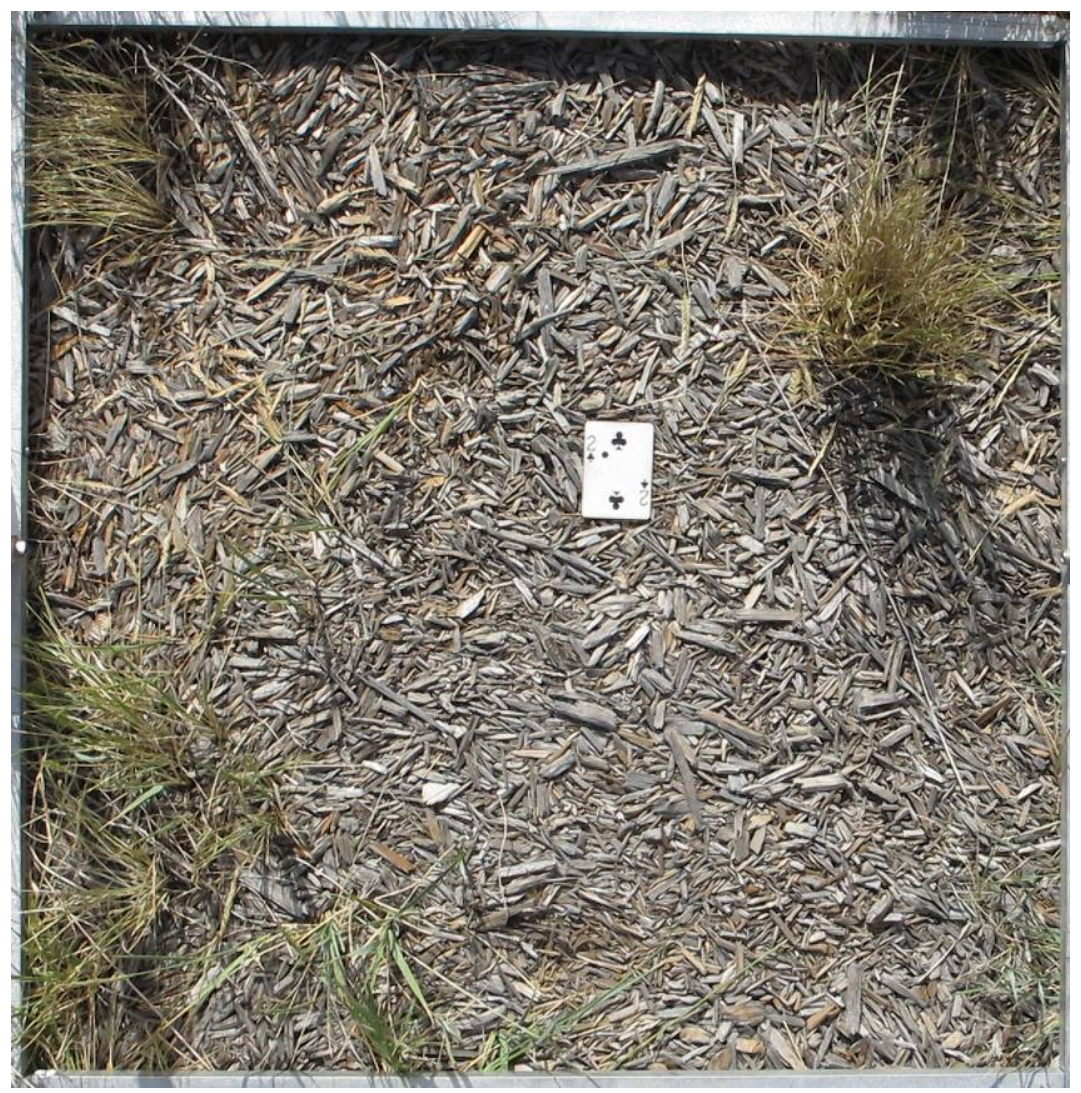

Figure B-6. Disturbed Vegetation Plot at the CFA Former Fire Station 2 Site. 


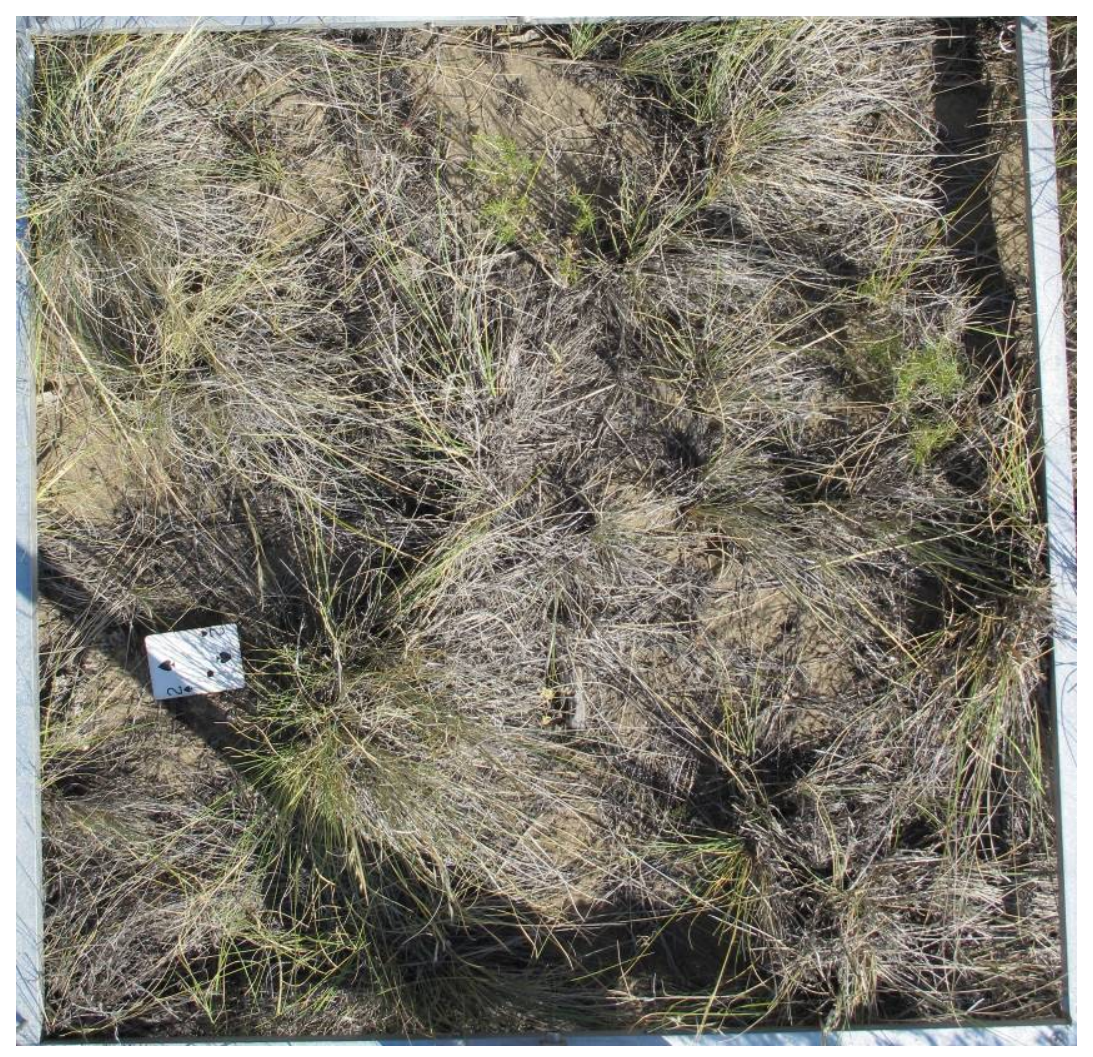

Figure B-7. Background Vegetation Plot at the Geomorphic Investigations for Flood Bounds.

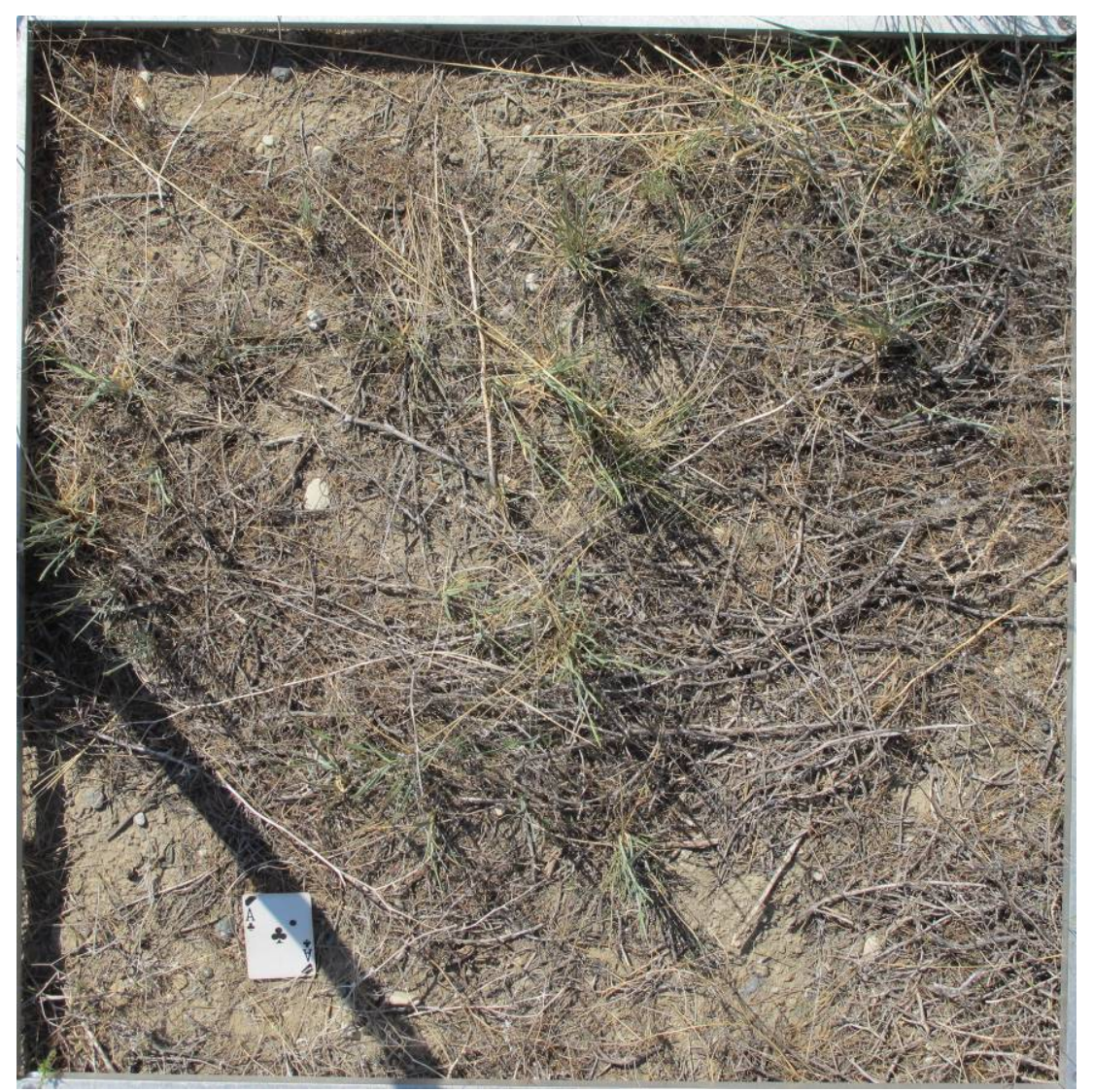

Figure B-8. Disturbed Vegetation Plot at the North Saddle Trench. 


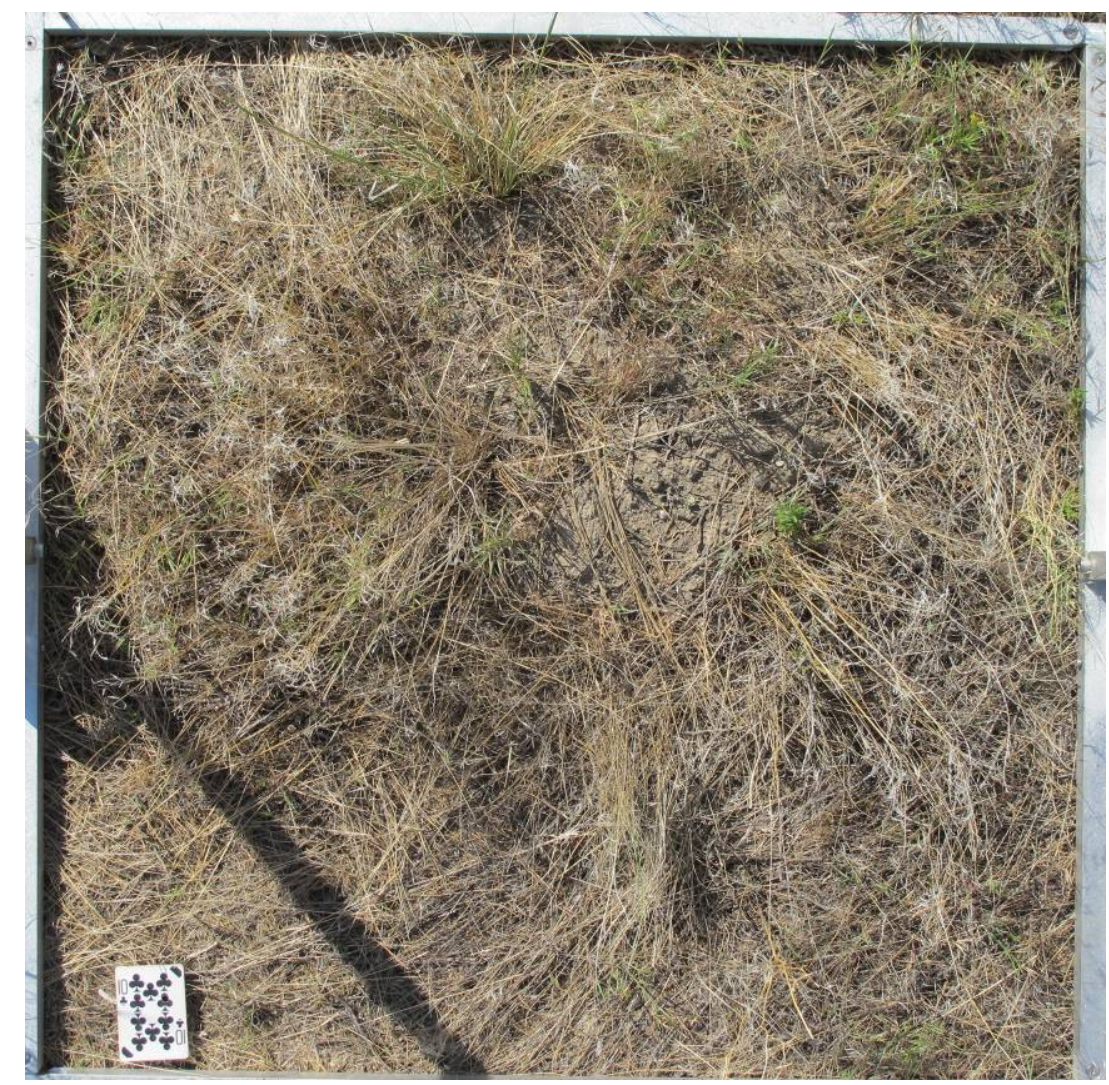

Figure B-9. Disturbed Vegetation Plot at the South Saddle Trench.

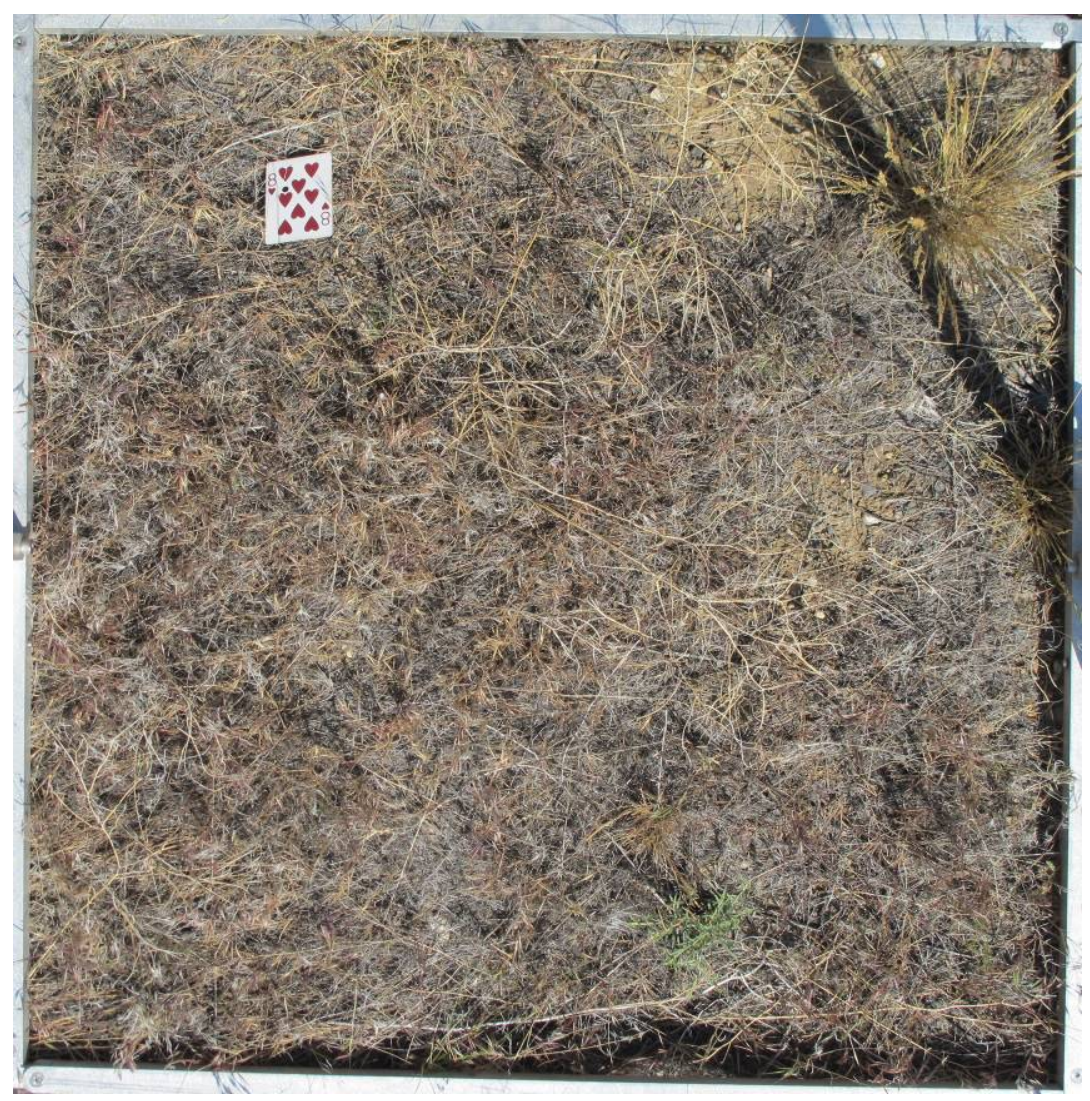

Figure B-10. Disturbed Vegetation Plot at the Southwest Big Loop Trench. 


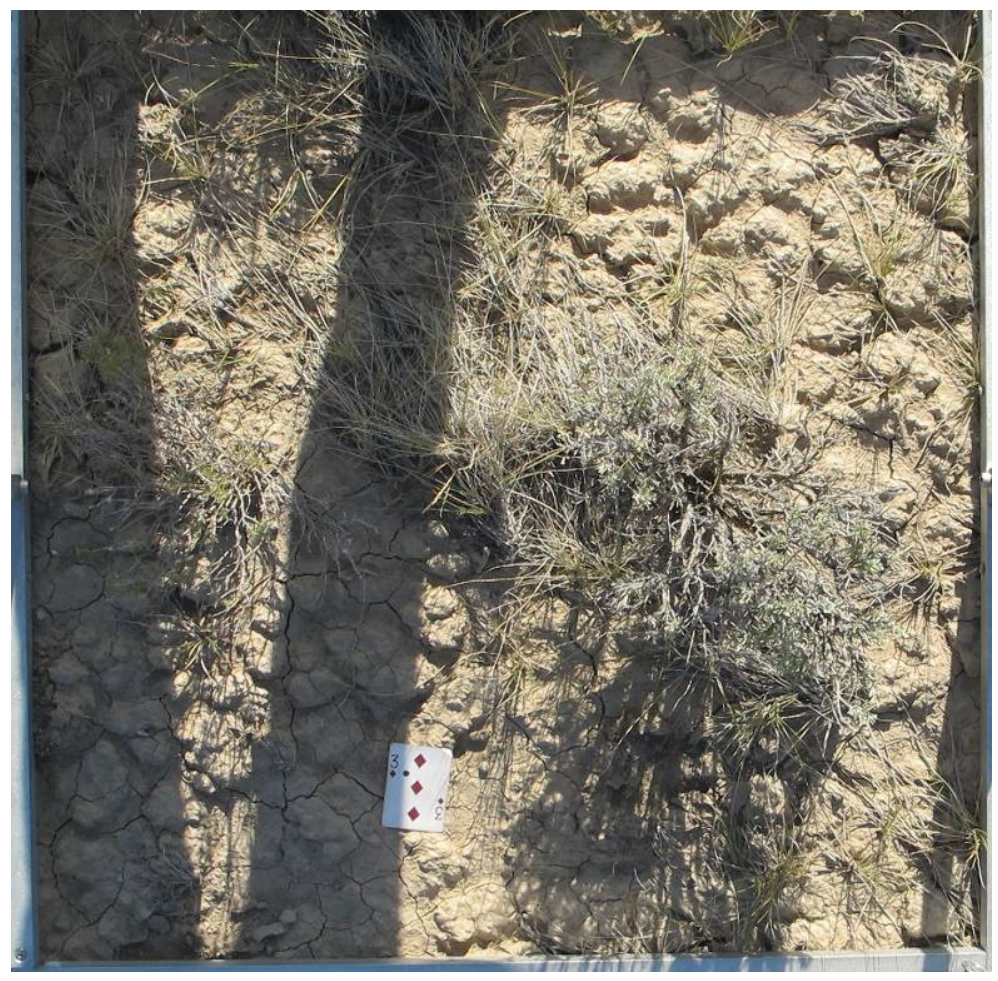

Figure B-11. Background Vegetation Plot at the Large Scale Infiltration Basin.

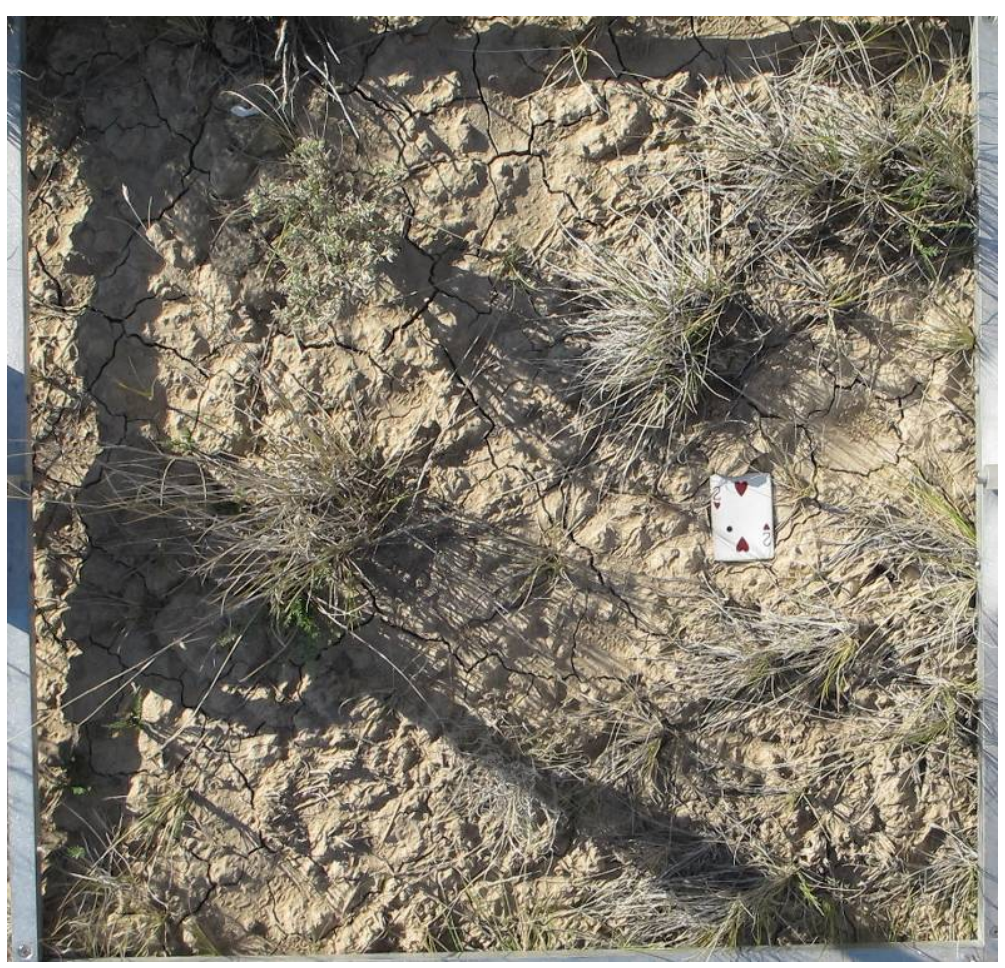

Figure B-12. Disturbed Vegetation Plot at the Large Scale Infiltration Basin. 


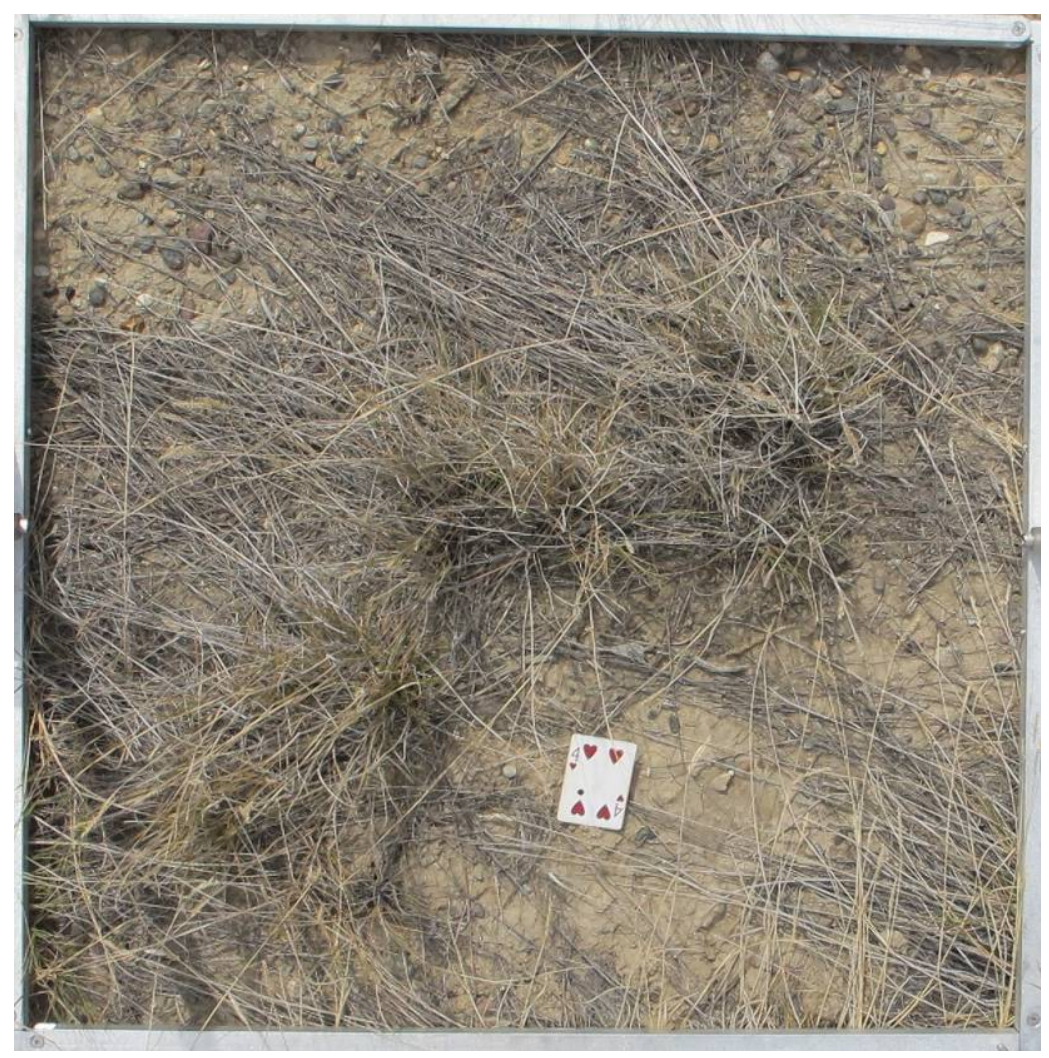

Figure B-13. Background Vegetation Plot at the Lincoln Boulevard Borrow Source.

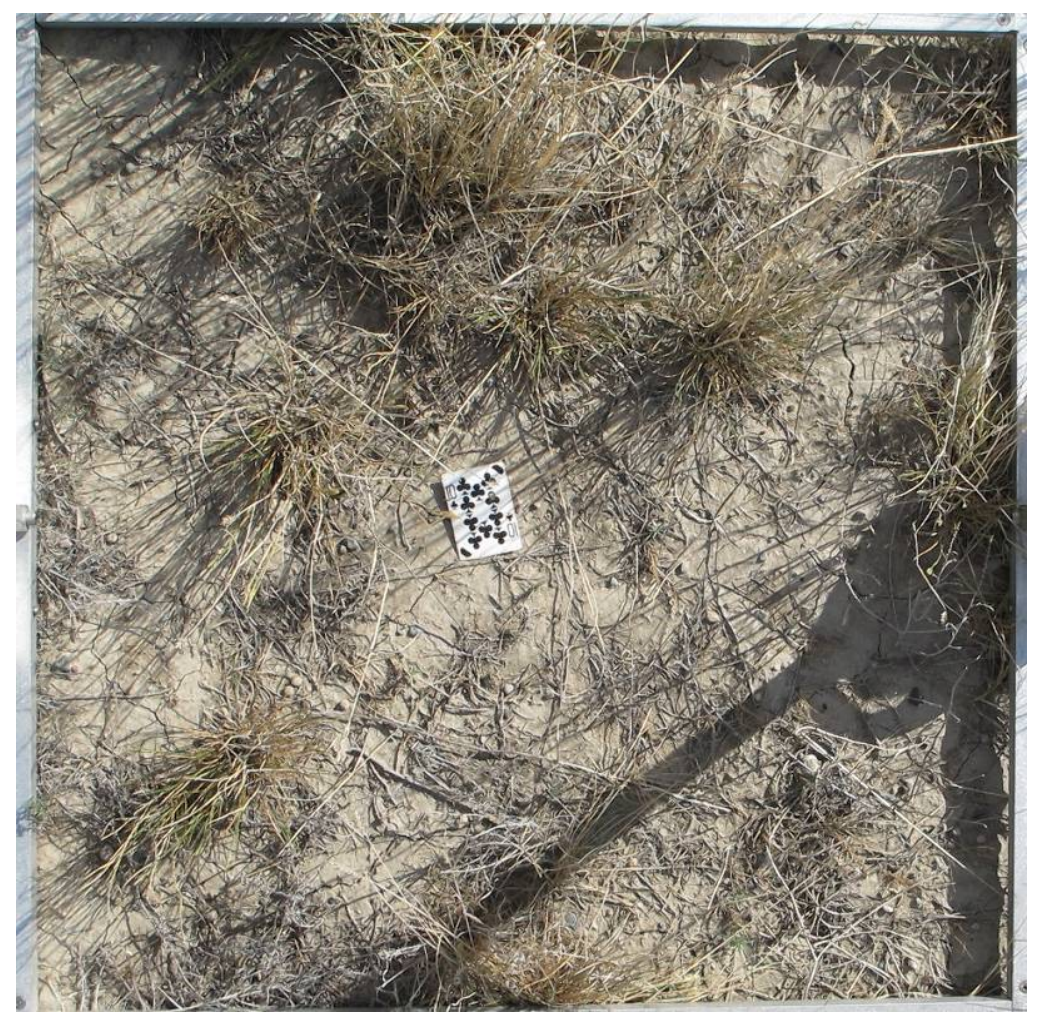

Figure B-14. Disturbed Vegetation Plot for the Lincoln Boulevard Borrow Source. 


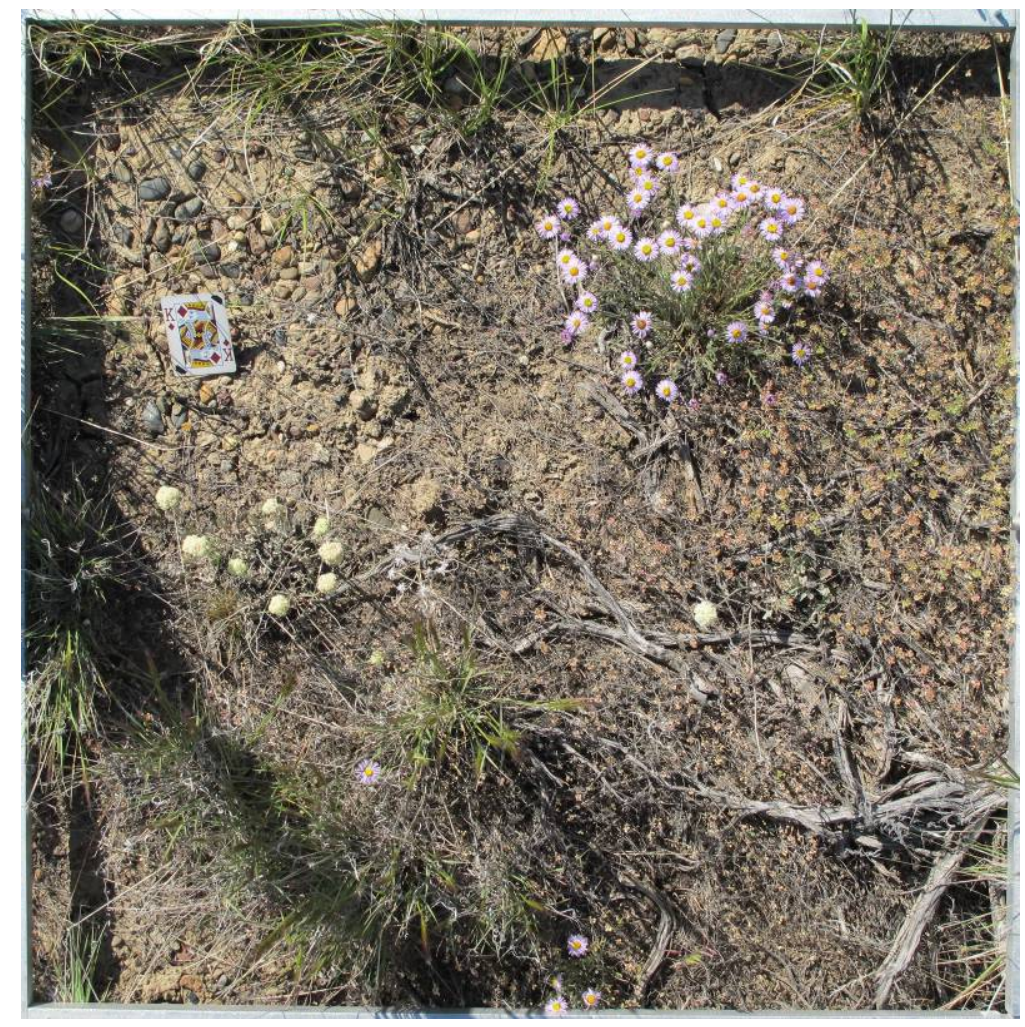

Figure B-15. Background Vegetation Plot for the VZRP.

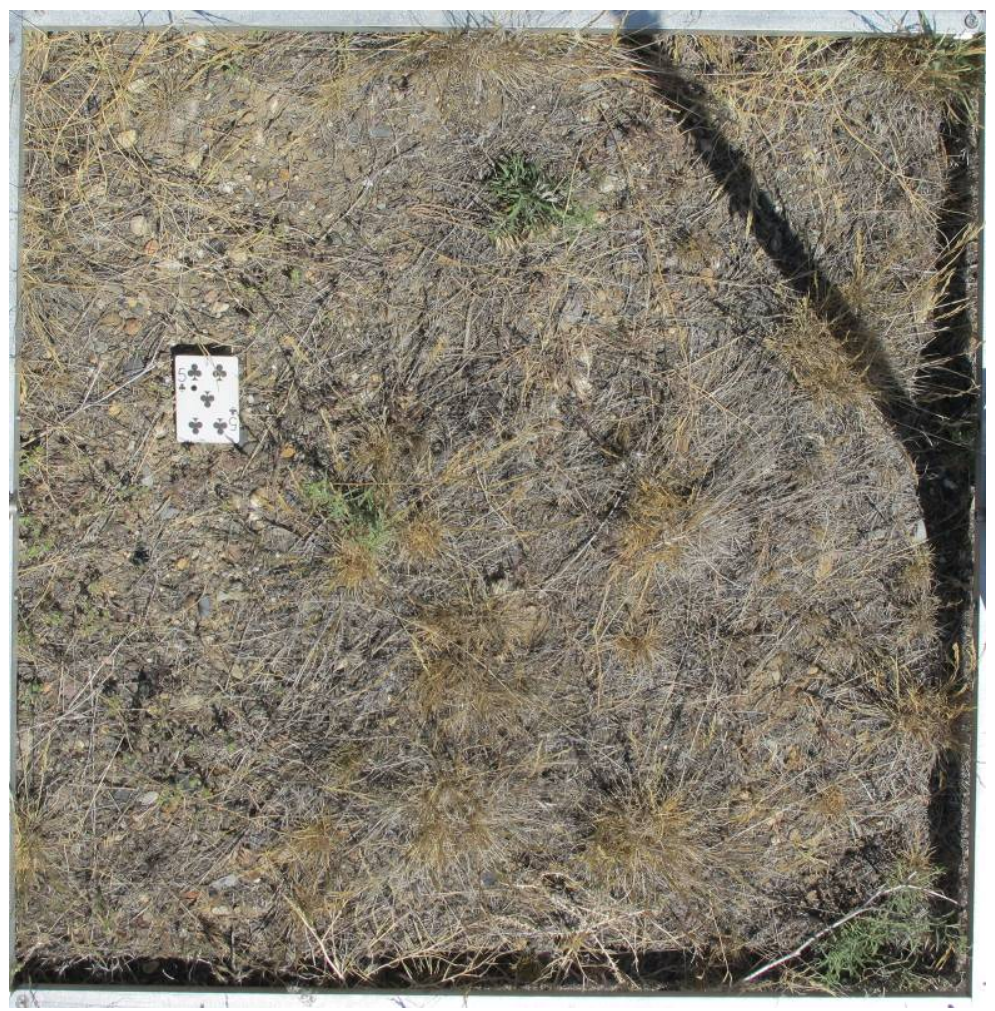

Figure B-16. Disturbed Vegetation Plot for Well 201A. 


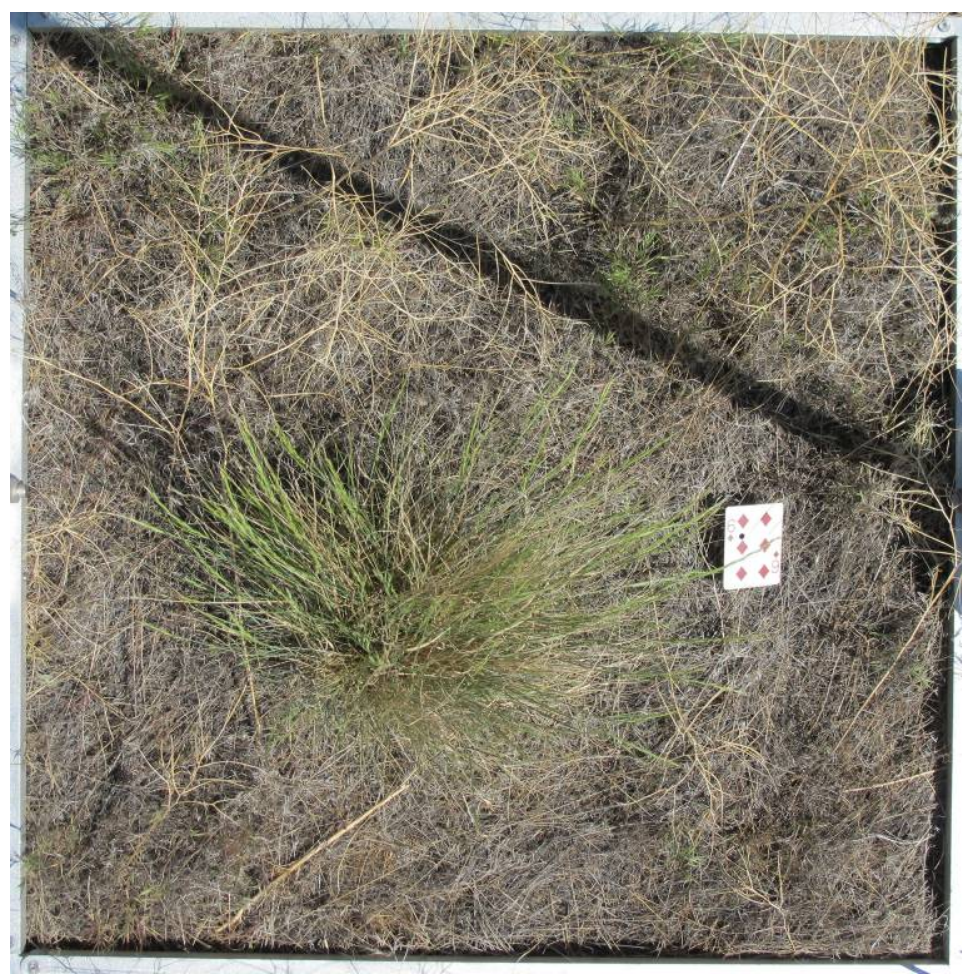

Figure B-17. Disturbed Vegetation Plot for Well 209. 


\section{Appendix C \\ GPS Coordinates}


Table C-1. BORAX-V GPS locations

\begin{tabular}{|c|c|}
\hline \multicolumn{2}{|l|}{ Borax-V } \\
\hline \multicolumn{2}{|l|}{ East } \\
\hline Waypoint & Latitude and Longitude \\
\hline 544 & N43 31.053 W113 00.550 \\
\hline 545 & N43 31.051 W11300.546 \\
\hline 546 & N43 31.051 W113 00.545 \\
\hline 547 & N43 31.048 W113 00.542 \\
\hline 548 & N43 31.050 W113 00.540 \\
\hline 549 & N43 31.050 W11300.537 \\
\hline 550 & N43 31.050 W113 00.535 \\
\hline 551 & N43 31.049 W113 00.533 \\
\hline 552 & N43 31.047 W113 00.531 \\
\hline 553 & N43 31.048 W11300.533 \\
\hline 554 & N43 31.047 W113 00.524 \\
\hline 555 & N43 31.048 W113 00.522 \\
\hline \multicolumn{2}{|l|}{ BKGD } \\
\hline Waypoint & Latitude and Longitude \\
\hline 556 & N43 31.040 W11300.517 \\
\hline 557 & N43 31.040 W113 00.520 \\
\hline 558 & N43 31.036 W11300.521 \\
\hline 559 & N43 31.033 W113 00.524 \\
\hline 560 & N43 31.032 W113 00.524 \\
\hline 561 & N43 31.028 W113 00.529 \\
\hline 562 & N43 31.027 W11300.531 \\
\hline 563 & N43 31.026 W113 00.533 \\
\hline 564 & N43 31.022 W113 00.537 \\
\hline \multicolumn{2}{|l|}{ West } \\
\hline Waypoint & Latitude and Longitude \\
\hline 565 & N43 31.021 W113 00.555 \\
\hline 566 & N43 31.022 W113 00.556 \\
\hline 567 & N43 31.025 W113 00.556 \\
\hline 568 & N43 31.025 W113 00.557 \\
\hline 569 & N43 31.029 W113 00.558 \\
\hline 570 & N43 31.032 W113 00.559 \\
\hline 571 & N43 31.035 W113 00.562 \\
\hline 572 & N43 31.037 W113 00.562 \\
\hline 573 & N43 31.039 W11300.564 \\
\hline 574 & N43 31.039 W113 00.564 \\
\hline 575 & N43 31.043 W113 00.566 \\
\hline 576 & N43 31.051 W113 00.566 \\
\hline 577 & N43 31.050 W11300.565 \\
\hline
\end{tabular}


Table C-2. CFA-04 Pond Remediation GPS Locations

\begin{tabular}{|c|c|}
\hline \multicolumn{2}{|c|}{ CFA-04 Pond } \\
\hline \multicolumn{2}{|l|}{$\mathrm{N}-\mathrm{S}$} \\
\hline Waypoint & Latitude and Longitude \\
\hline 579 & N43 31.395 W112 56.798 \\
\hline 580 & N43 31.390 W112 56.799 \\
\hline 581 & N43 31.387 W112 56.798 \\
\hline 582 & N43 31.383 W112 56.798 \\
\hline 583 & N43 31.379 W112 56.797 \\
\hline 584 & N43 31.374 W112 56.794 \\
\hline 585 & N43 31.368 W112 56.792 \\
\hline 586 & N43 31.368 W112 56.791 \\
\hline 587 & N43 31.363 W112 56.791 \\
\hline 588 & N43 31.363 W112 56.792 \\
\hline 589 & N43 31.362 W112 56.792 \\
\hline 590 & N43 31.351 W112 56.791 \\
\hline 591 & N43 31.342 W112 56.791 \\
\hline 592 & N43 31.338 W112 56.790 \\
\hline 593 & N43 31.332 W112 56.789 \\
\hline 594 & N43 31.330 W112 56.787 \\
\hline 595 & N43 31.328 W112 56.790 \\
\hline \multicolumn{2}{|l|}{ BKGD } \\
\hline Waypoint & Latitude and Longitude \\
\hline 596 & N43 31.315 W112 56.791 \\
\hline 597 & N43 31.315 W112 56.791 \\
\hline 598 & N43 31.310 W112 56.788 \\
\hline 599 & N43 31.308 W112 56.786 \\
\hline 600 & N43 31.304 W112 56.786 \\
\hline 601 & N43 31.297 W112 56.773 \\
\hline 602 & N43 31.295 W112 56.771 \\
\hline 603 & N43 31.295 W112 56.769 \\
\hline 604 & N43 31.295 W112 56.763 \\
\hline 605 & N43 31.295 W112 56.760 \\
\hline 606 & N43 31.296 W112 56.753 \\
\hline 607 & N43 31.297 W112 56.754 \\
\hline 608 & N43 31.305 W112 56.750 \\
\hline 609 & N43 31.308 W112 56.747 \\
\hline 610 & N43 31.315 W112 56.745 \\
\hline 611 & N43 31.321 W112 56.737 \\
\hline 612 & N43 31.321 W112 56.730 \\
\hline 613 & N43 31.324 W112 56.729 \\
\hline
\end{tabular}




\begin{tabular}{|ll|}
\hline 614 & N43 31.324 W112 56.729 \\
\hline 615 & N43 31.334 W112 56.724 \\
\hline 616 & N43 31.339 W112 56.725 \\
\hline 617 & N43 31.342 W112 56.723 \\
\hline E-W & \\
\hline Waypoint & Latitude and Longitude \\
\hline 618 & N43 31.358 W112 56.736 \\
\hline 619 & N43 31.357 W112 56.736 \\
\hline 620 & N43 31.359 W112 56.750 \\
\hline 621 & N43 31.357 W112 56.755 \\
\hline 622 & N43 31.356 W112 56.761 \\
\hline 623 & N43 31.358 W112 56.767 \\
\hline 624 & N43 31.357 W112 56.768 \\
\hline 625 & N43 31.358 W112 56.779 \\
\hline 626 & N43 31.358 W112 56.784 \\
\hline 627 & N43 31.358 W112 56.793 \\
\hline 628 & N43 31.359 W112 56.801 \\
\hline 629 & N43 31.360 W112 56.801 \\
\hline 630 & N43 31.362 W112 56.818 \\
\hline 631 & N43 31.364 W112 56.824 \\
\hline 632 & N43 31.366 W112 56.835 \\
\hline 633 & N43 31.365 W112 56.841 \\
\hline 634 & N43 31.365 W112 56.840 \\
\hline 635 & N43 31.367 W112 56.853 \\
\hline 636 & N43 31.370 W112 56.858 \\
\hline
\end{tabular}


Table C-3. CFA Former Fire Station 2 GPS Locations.

\begin{tabular}{|c|c|}
\hline \multicolumn{2}{|c|}{ Fire Station $\# 2$} \\
\hline \multicolumn{2}{|l|}{ W-E } \\
\hline Waypoint & Latitude and Longitude \\
\hline \multicolumn{2}{|r|}{ N43 35.801 W112 56.449} \\
\hline \multicolumn{2}{|r|}{ N43 35.800 W112 56.451 } \\
\hline \multicolumn{2}{|r|}{ N43 35.799 W112 56.443} \\
\hline \multicolumn{2}{|r|}{ N43 35.801 W112 56.442} \\
\hline \multicolumn{2}{|l|}{$\mathrm{N}-\mathrm{S}$} \\
\hline Waypoint & Latitude and Longitude \\
\hline \multicolumn{2}{|r|}{ N43 35.787 W112 56.450} \\
\hline \multicolumn{2}{|r|}{ N43 35.787 W112 56.448} \\
\hline \multicolumn{2}{|r|}{ N43 35.787 W112 56.446} \\
\hline \multicolumn{2}{|r|}{ N43 35.792 W112 56.447} \\
\hline \multicolumn{2}{|r|}{ N43 35.792 W112 56.447} \\
\hline \multicolumn{2}{|r|}{ N43 35.794 W112 56.445} \\
\hline \multicolumn{2}{|r|}{ N43 35.796 W112 56.446} \\
\hline \multicolumn{2}{|r|}{ N43 35.800 W112 56.445} \\
\hline \multicolumn{2}{|r|}{ N43 35.803 W112 56.443} \\
\hline \multicolumn{2}{|c|}{ Background } \\
\hline Waypoint & Latitude and Longitude \\
\hline 525 & N43 35.758 W112 56.476 \\
\hline 526 & N43 35.760 W112 56.469 \\
\hline 527 & N43 35.758 W112 56.463 \\
\hline 528 & N43 35.759 W112 56.461 \\
\hline 529 & N43 35.757 W112 56.456 \\
\hline 530 & N43 35.755 W112 56.452 \\
\hline 531 & N43 35.752 W112 56.449 \\
\hline 532 & N43 35.752 W112 56.448 \\
\hline 533 & N43 35.751 W112 56.441 \\
\hline 534 & N43 35.747 W112 56.438 \\
\hline 535 & N43 35.745 W112 56.434 \\
\hline 536 & N43 35.743 W112 56.426 \\
\hline 537 & N43 35.741 W112 56.423 \\
\hline 538 & N43 35.739 W112 56.414 \\
\hline 539 & N43 35.736 W112 56.410 \\
\hline 540 & N43 35.733 W112 56.406 \\
\hline 541 & N43 35.731 W112 56.403 \\
\hline 542 & N43 35.728 W112 56.397 \\
\hline
\end{tabular}


Table C-4.Saddle Trenches Disturbed Area GPS Locations.

\begin{tabular}{|l|l|}
\hline \multicolumn{2}{|l|}{ Saddle Trenches } \\
\hline \hline \multicolumn{2}{|l|}{ South } \\
\hline Waypoint & Latitude and Longitude \\
\hline 410 & N43 31.625 W113 03.380 \\
\hline 411 & N43 31.632 W113 03.382 \\
\hline 412 & N43 31.632 W113 03.384 \\
\hline 413 & N43 31.634 W113 03.387 \\
\hline 414 & N43 31.634 W113 03.388 \\
\hline 415 & N43 31.635 W113 03.390 \\
\hline 416 & N43 31.637 W113 03.392 \\
\hline 417 & N43 31.638 W113 03.393 \\
\hline 418 & N43 31.638 W113 03.394 \\
\hline North & \\
\hline Waypoint & Latitude and Longitude \\
\hline 419 & N43 31.662 W113 03.419 \\
\hline 420 & N43 31.658 W113 03.413 \\
\hline 421 & N43 31.659 W113 03.414 \\
\hline 422 & N43 31.656 W113 03.410 \\
\hline 423 & N43 31.657 W113 03.409 \\
\hline 424 & N43 31.655 W113 03.406 \\
\hline 425 & N43 31.658 W113 03.396 \\
\hline
\end{tabular}

Table C-5. Southwest Big Loop Disturbed Area GPS Locations.

\begin{tabular}{|l|l|}
\hline \multicolumn{2}{|l|}{ SW-Big Loop Trench } \\
\hline \hline Waypoint & Latitude and Longitude \\
\hline \hline 426 & N43 31.261 W113 04.228 \\
\hline 427 & N43 31.262 W113 04.228 \\
\hline 428 & N43 31.261 W113 04.224 \\
\hline 429 & N43 31.261 W113 04.223 \\
\hline 430 & N43 31.262 W113 04.226 \\
\hline 431 & N43 31.264 W113 04.232 \\
\hline 432 & N43 31.266 W113 04.231 \\
\hline 433 & N43 31.264 W113 04.230 \\
\hline 434 & N43 31.269 W113 04.237 \\
\hline 435 & N43 31.270 W113 04.238 \\
\hline 436 & N43 31.271 W113 04.238 \\
\hline 437 & N43 31.272 W113 04.239 \\
\hline 438 & N43 31.274 W113 04.240 \\
\hline 439 & N43 31.276 W113 04.243 \\
\hline 440 & N43 31.276 W113 04.243 \\
\hline 441 & N43 31.276 W113 04.243 \\
\hline
\end{tabular}




\begin{tabular}{|ll|}
\hline 442 & N43 31.276 W113 04.247 \\
\hline 443 & N43 31.278 W113 04.247 \\
\hline 444 & N43 31.280 W113 04.250 \\
\hline 445 & N43 31.279 W113 04.250 \\
\hline 446 & N43 31.283 W113 04.253 \\
\hline
\end{tabular}

Table C-6. Geomorphic Investigations for Flood Bounds Background GPS Locations.

\begin{tabular}{|c|c|}
\hline \multicolumn{2}{|c|}{ Background GI Project } \\
\hline Waypoint & Latitude and Longitude \\
\hline 380 & N43 31.957 W113 02.684 \\
\hline 381 & N43 31.955 W113 02.689 \\
\hline 382 & N43 31.955 W113 02.707 \\
\hline 383 & N43 31.950 W113 02.705 \\
\hline 384 & N43 31.947 W11302.705 \\
\hline 385 & N43 31.947 W11302.709 \\
\hline 386 & N43 31.946 W113 02.710 \\
\hline 387 & N43 31.945 W113 02.711 \\
\hline 388 & N43 31.943 W11302.714 \\
\hline 389 & N43 31.943 W113 02.715 \\
\hline 390 & N43 31.942 W113 02.718 \\
\hline 391 & N43 31.942 W113 02.719 \\
\hline
\end{tabular}

Table C-7. Large Scale Infiltration Basin GPS Locations.

\begin{tabular}{|l|l|}
\hline \multicolumn{2}{|l|}{ Large Scale Infiltration Basin } \\
\hline \hline W-E & \multicolumn{2}{l|}{} \\
\hline Waypoint & Latitude and Longitude \\
\hline 650 & N43 28.873 W113 02.369 \\
\hline 651 & N43 28.873 W113 02.367 \\
\hline 652 & N43 28.871 W113 02.357 \\
\hline 653 & N43 28.873 W113 02.357 \\
\hline 654 & N43 28.874 W113 02.351 \\
\hline 655 & N43 28.872 W113 02.346 \\
\hline 656 & N43 28.875 W113 02.340 \\
\hline 657 & N43 28.877 W113 02.334 \\
\hline 658 & N43 28.878 W113 02.336 \\
\hline 659 & N43 28.883 W113 02.323 \\
\hline 660 & N43 28.881 W113 02.323 \\
\hline 661 & N43 28.881 W113 02.319 \\
\hline 662 & N43 28.884 W113 02.308 \\
\hline 663 & N43 28.885 W113 02.305 \\
\hline 664 & N43 28.883 W113 02.296 \\
\hline 665 & N43 28.886 W113 02.290 \\
\hline
\end{tabular}




\begin{tabular}{|c|c|}
\hline 666 & N43 28.887 W113 02.286 \\
\hline 667 & N43 28.890 W113 02.280 \\
\hline 668 & N43 28.890 W113 02.277 \\
\hline 669 & N43 28.889 W113 02.271 \\
\hline 670 & N43 28.887 W113 02.264 \\
\hline 671 & N43 28.889 W113 02.259 \\
\hline 672 & N43 28.894 W113 02.251 \\
\hline 673 & N43 28.895 W113 02.246 \\
\hline 674 & N43 28.896 W113 02.241 \\
\hline 675 & N43 28.899 W113 02.239 \\
\hline \multicolumn{2}{|l|}{ S-N } \\
\hline Waypoint & Latitude and Longitude \\
\hline 676 & N43 28.850 W113 02.264 \\
\hline 677 & N43 28.855 W113 02.268 \\
\hline 678 & N43 28.858 W113 02.267 \\
\hline 679 & N43 28.860 W113 02.266 \\
\hline 680 & N43 28.864 W113 02.268 \\
\hline 681 & N43 28.870 W113 02.273 \\
\hline 682 & N43 28.874 W113 02.274 \\
\hline 683 & N43 28.877 W113 02.278 \\
\hline 684 & N43 28.883 W113 02.283 \\
\hline 685 & N43 28.887 W113 02.286 \\
\hline 686 & N43 28.887 W113 02.286 \\
\hline 687 & N43 28.891 W113 02.294 \\
\hline 688 & N43 28.896 W113 02.297 \\
\hline 689 & N43 28.905 W113 02.309 \\
\hline 690 & N43 28.908 W113 02.310 \\
\hline 691 & N43 28.908 W113 02.309 \\
\hline 692 & N43 28.913 W113 02.312 \\
\hline 693 & N43 28.914 W113 02.318 \\
\hline 694 & N43 28.919 W113 02.314 \\
\hline 695 & N43 28.924 W113 02.312 \\
\hline 696 & N43 28.932 W113 02.319 \\
\hline 697 & N43 28.936 W113 02.324 \\
\hline \multicolumn{2}{|l|}{ BKGD } \\
\hline Waypoint & Latitude and Longitude \\
\hline 698 & N43 28.868 W113 02.379 \\
\hline 699 & N43 28.868 W113 02.389 \\
\hline 700 & N43 28.865 W113 02.396 \\
\hline 701 & N43 28.863 W113 02.401 \\
\hline 702 & N43 28.862 W113 02.406 \\
\hline 703 & N43 28.861 W11302.407 \\
\hline 704 & N43 28.861 W113 02.417 \\
\hline
\end{tabular}




\begin{tabular}{|ll|}
\hline 705 & N43 28.861 W113 02.423 \\
\hline 706 & N43 28.858 W113 02.427 \\
\hline 707 & N43 28.854 W113 02.443 \\
\hline 708 & N43 28.857 W113 02.455 \\
\hline 709 & N43 28.857 W113 02.459 \\
\hline 710 & N43 28.856 W113 02.459 \\
\hline 711 & N43 28.855 W113 02.464 \\
\hline 712 & N43 28.852 W113 02.469 \\
\hline
\end{tabular}

Table C-8. Lincoln Boulevard Borrow Source Disturbed Area GPS Locations.

\begin{tabular}{|l|l|}
\hline \multicolumn{2}{|l|}{ Lincoln Boulevard Borrow Source } \\
\hline \hline North & \\
\hline Waypoint & Latitude and Longitude \\
\hline 480 & N43 40.091 W112 52.234 \\
\hline 481 & N43 40.090 W112 52.236 \\
\hline 482 & N43 40.088 W112 52.228 \\
\hline 483 & N43 40.085 W112 52.239 \\
\hline 484 & N43 40.084 W112 52.243 \\
\hline 485 & N43 40.085 W112 52.244 \\
\hline 486 & N43 40.086 W112 52.236 \\
\hline 487 & N43 40.083 W112 52.244 \\
\hline 488 & N43 40.080 W112 52.248 \\
\hline 489 & N43 40.079 W112 52.249 \\
\hline 490 & N43 40.076 W112 52.253 \\
\hline 491 & N43 40.074 W112 52.256 \\
\hline 492 & N43 40.071 W112 52.258 \\
\hline 493 & N43 40.071 W112 52.258 \\
\hline 494 & N43 40.069 W112 52.266 \\
\hline 495 & N43 40.065 W112 52.271 \\
\hline 496 & N43 40.064 W112 52.271 \\
\hline 497 & N43 40.062 W112 52.273 \\
\hline 498 & N43 40.060 W112 52.277 \\
\hline 499 & N43 40.058 W112 52.279 \\
\hline 500 & N43 40.054 W112 52.284 \\
\hline 501 & N43 40.053 W112 52.286 \\
\hline 502 & N43 40.051 W112 52.287 \\
\hline 503 & N43 40.048 W112 52.293 \\
\hline 504 & N43 40.046 W112 52.293 \\
\hline 505 & N43 40.044 W112 52.296 \\
\hline 506 & N43 40.043 W112 52.297 \\
\hline 507 & N43 40.040 W112 52.301 \\
\hline 508 & N112 52.311 \\
\hline 509 & N2.302 \\
\hline
\end{tabular}




\begin{tabular}{|l|l|}
\hline South & \\
\hline Waypoint & Latitude and Longitude \\
\hline 510 & N43 40.015 W112 52.322 \\
\hline 511 & N43 40.015 W112 52.323 \\
\hline 512 & N43 40.017 W112 52.325 \\
\hline 513 & N43 40.014 W112 52.329 \\
\hline 514 & N43 40.013 W112 52.331 \\
\hline 515 & N43 40.012 W112 52.332 \\
\hline 516 & N43 40.009 W112 52.336 \\
\hline 517 & N43 40.008 W112 52.341 \\
\hline 518 & N43 40.006 W112 52.341 \\
\hline 519 & N43 40.003 W112 52.345 \\
\hline 520 & N43 40.001 W112 52.341 \\
\hline 521 & N43 39.998 W112 52.349 \\
\hline 522 & N43 39.996 W112 52.350 \\
\hline 523 & N43 39.993 W112 52.355 \\
\hline 524 & N43 39.992 W112 52.358 \\
\hline
\end{tabular}

Table C-9. VZRP GPS locations.

\begin{tabular}{|l|l|}
\hline \multicolumn{2}{|l|}{ VZRP Well 209} \\
\hline \hline \multicolumn{2}{|l|}{ T1 } \\
\hline Waypoint & Latitude and Longitude \\
\hline 447 & N43 33.262 W112 58.362 \\
\hline 448 & N43 33.263 W112 58.363 \\
\hline 449 & N43 33.259 W112 58.366 \\
\hline 450 & N43 33.259 W112 58.364 \\
\hline 451 & N43 33.259 W112 58.362 \\
\hline 452 & N43 33.258 W112 58.362 \\
\hline 453 & N43 33.257 W112 58.363 \\
\hline 454 & N43 33.253 W112 58.362 \\
\hline 455 & N43 33.252 W112 58.364 \\
\hline 456 & N43 33.252 W112 58.364 \\
\hline T2 & \\
\hline Waypoint & Latitude and Longitude \\
\hline 457 & N43 33.256 W112 58.363 \\
\hline 458 & N43 33.257 W112 58.364 \\
\hline 459 & N43 33.257 W112 58.363 \\
\hline 460 & N43 33.259 W112 58.363 \\
\hline 461 & N43 33.260 W112 58.364 \\
\hline 462 & N43 33.261 W112 58.365 \\
\hline 463 & N43 33.260 W112 58.368 \\
\hline 464 & N43 33.263 W112 58.367 \\
\hline 465 & N43 33.263 W112 58.367 \\
\hline
\end{tabular}




\begin{tabular}{|c|c|}
\hline \multicolumn{2}{|c|}{ VZRP Well 201A } \\
\hline \multicolumn{2}{|l|}{$\mathrm{T} 1$} \\
\hline Waypoint & Latitude and Longitude \\
\hline 466 & N43 33.265 W112 58.266 \\
\hline 467 & N43 33.261 W112 58.264 \\
\hline 468 & N43 33.262 W112 58.261 \\
\hline 469 & N43 33.261 W112 58.261 \\
\hline 470 & N43 33.253 W112 58.254 \\
\hline 471 & N43 33.254 W112 58.258 \\
\hline 472 & N43 33.254 W112 58.259 \\
\hline 473 & N43 33.254 W112 58.260 \\
\hline \multicolumn{2}{|l|}{$\mathrm{T} 2$} \\
\hline Waypoint & Latitude and Longitude \\
\hline 474 & N43 33.256 W112 58.254 \\
\hline 475 & N43 33.255 W112 58.254 \\
\hline 476 & N43 33.255 W112 58.256 \\
\hline 477 & N43 33.259 W112 58.257 \\
\hline 478 & N43 33.261 W112 58.257 \\
\hline 479 & N43 33.263 W112 58.258 \\
\hline \multicolumn{2}{|c|}{ VZRP Background } \\
\hline Waypoint & Latitude and Longitude \\
\hline 47 & N43 33.634 W112 58.338 \\
\hline 48 & N43 33.635 W112 58.341 \\
\hline 49 & N43 33.635 W112 58.342 \\
\hline 50 & N43 33.636 W112 58.344 \\
\hline 51 & N43 33.636 W112 58.345 \\
\hline 52 & N43 33.637 W112 58.347 \\
\hline 53 & N43 33.638 W112 58.348 \\
\hline 54 & N43 33.638 W112 58.350 \\
\hline 55 & N43 33.639 W112 58.351 \\
\hline 56 & N43 33.640 W112 58.352 \\
\hline 57 & N43 33.640 W112 58.354 \\
\hline 58 & N43 33.641 W112 58.356 \\
\hline 59 & N43 33.642 W112 58.358 \\
\hline 60 & N43 33.644 W112 58.359 \\
\hline 61 & N43 33.645 W112 58.361 \\
\hline 62 & N43 33.646 W112 58.362 \\
\hline 63 & N43 33.646 W112 58.363 \\
\hline 64 & N43 33.647 W112 58.365 \\
\hline 65 & N43 33.648 W112 58.367 \\
\hline 66 & N43 33.648 W112 58.368 \\
\hline 67 & N43 33.648 W112 58.370 \\
\hline
\end{tabular}




\begin{tabular}{|c|c|}
\hline 102 & N43 33.490 W112 58.178 \\
\hline 103 & N43 33.490 W112 58.176 \\
\hline 104 & N43 33.490 W112 58.175 \\
\hline 105 & N43 33.490 W112 58.173 \\
\hline 106 & N43 33.490 W112 58.171 \\
\hline 107 & N43 33.490 W112 58.170 \\
\hline 108 & N43 33.490 W112 58.168 \\
\hline 109 & N43 33.490 W112 58.166 \\
\hline 110 & N43 33.490 W112 58.164 \\
\hline 111 & N43 33.490 W112 58.162 \\
\hline 112 & N43 33.490 W112 58.160 \\
\hline 113 & N43 33.490 W112 58.158 \\
\hline 114 & N43 33.489 W112 58.156 \\
\hline 115 & N43 33.489 W112 58.154 \\
\hline 116 & N43 33.489 W112 58.152 \\
\hline 117 & N43 33.489 W112 58.150 \\
\hline 118 & N43 33.488 W112 58.149 \\
\hline 140 & N43 33.418 W112 58.463 \\
\hline 141 & N43 33.417 W112 58.465 \\
\hline 142 & N43 33.416 W112 58.465 \\
\hline 143 & N43 33.415 W112 58.466 \\
\hline 144 & N43 33.413 W112 58.468 \\
\hline 145 & N43 33.412 W112 58.470 \\
\hline 146 & N43 33.411 W112 58.471 \\
\hline 147 & N43 33.410 W112 58.472 \\
\hline 148 & N43 33.407 W112 58.476 \\
\hline 149 & N43 33.407 W112 58.476 \\
\hline 150 & N43 33.406 W112 58.477 \\
\hline 151 & N43 33.406 W112 58.479 \\
\hline 152 & N43 33.405 W112 58.481 \\
\hline 153 & N43 33.406 W112 58.481 \\
\hline 154 & N43 33.404 W112 58.485 \\
\hline 208 & N43 33.008 W112 58.597 \\
\hline 209 & N43 33.008 W112 58.599 \\
\hline 210 & N43 33.007 W112 58.600 \\
\hline 211 & N43 33.006 W112 58.602 \\
\hline 212 & N43 33.004 W112 58.607 \\
\hline 213 & N43 33.005 W112 58.611 \\
\hline 214 & N43 33.005 W112 58.611 \\
\hline 215 & N43 33.007 W112 58.609 \\
\hline 216 & N43 33.007 W112 58.611 \\
\hline 217 & N43 33.006 W112 58.616 \\
\hline 218 & N43 33.009 W112 58.615 \\
\hline
\end{tabular}




\begin{tabular}{|ll|}
\hline 219 & N43 33.009 W112 58.615 \\
\hline 220 & N43 33.008 W112 58.617 \\
\hline 221 & N43 33.007 W112 58.616 \\
\hline 222 & N43 33.009 W112 58.617 \\
\hline
\end{tabular}

